\title{
J. ACTA RELATIVA A LAS CONDICIONES DE ADHESION DEL REINO DE ESPAÑA Y DE LA REPUBLICA PORTUGUESA Y A LAS ADAPTACIONES DE LOS TRATADOS (salvo los artículos 189 a 380 referentes a la República Portuguesa)
}

\section{PRIMERA PARTE}

\section{PRINCIPIOS}

Artículo 1. Con arreglo a la presente Acta:

- se entenderá por «Tratados originarios», el Tratado constitutivo de la Comunidad Europea del Carbón y del Acero, el Tratado constitutivo de la Comunidad Económica Europea y el Tratado constitutivo de la Comunidad Europea de la Energía Atómica, tal como han sido completados o modificados mediante tratados o mediante otros actos que - hayan entrado en vigor antes de la presente adhesión; se entenderá por «Tratado CECA», "Tratado CEE», "Tratado CEEA), los Tratados originarios correspondientes así completados o modificados;

- se entenderá por «Estados miembros actuales», el Reino de Bélgica, el Reino de Dinamarca; la República - Federal de Alemania, la República Helénica, la República Francesa, Irlanda, la República Italiana, el
Gran Ducado de Luxemburgo, el Reino de los Países Bajos y el Reino Unido de Gran Bretaña e Irlanda del Norte;

- se entenderá por «Comunidad en su composición actual», la Comunidad compuesta por los Estados miembros actuales;

- se entenderá por «Comunidad en su composición ampliadas, la Comunidad en su composición posterior tanto a la adhesión de 1972 como a la de 1979;

- se entenderá por «nuevos Estados miembros", el Reino de España y la Repúblizca Portuguesa.

Art. 2. Desde el momento de la adhesión, las disposiciones de los Tratados originarios y los actos adoptados por las instituciones de las Comunidades antes de la adhesión obligarán a los nuevos Estados miembros y serán aplicables en dichos Estados en las condiciones previstas en estos Tratados y en la presente Acta.

Art. 3. 1. Los nuevos Estados miembros se adhieren, por medio de la presente Acta, a las decisiones y acuer- 
dos adoptados por los representantes de los Gobiernos de los Estados miembros reunidos en el seno del Consejo. Se comprometen a adherirse, desde el momento de la adhesión, a cualquier otro acuerdo celebrado por los Estados miembros actuales relativos al funcionamiento de las Comunidades o que guarde relación con la acción de éstas.

2. Los nuevos Estados miembros se comprometen a adherirse a los convenios contemplados en el artículo $220 \mathrm{del}$ Tratado CEE, al igual que a aquellos que no puedan disociarse de la consecución de los objetivos de este Tratado y que, por consiguiente, estén vinculados al ordenamiento jurídico comunitario, así como a los protocolos relativos a la interpretación de estos convenios por el Tribunal de Justicia, firmados por los Estados miembros de la Comunidad en su composición originaria o ampliada, y a entablar, a tal fin, negociaciones con los Estados miembros actuales para efectuar en aquéllos las adaptaciones necesarias.

3. Los nuevos Estados miembros se hallan en la misma situación que los Estados miembros actuales respecto de las declaraciones, resoluciones $u$ otras posiciones adoptadas por el Consejo, así como respecto de aquéllas relativas a las Comunidades Europeas adoptadas de común acuerdo por los Estados miembros; por consiguiente, respetarán los principios y orientaciones que se desprenden de las mismas y adoptarán las medidas que puedan resultar necesarias para asegurar su aplicación.

Art. 4. 1. Los acuerdos o convenios suscritos por una de las Comunidades con uno o varios terceros Estados, una organización internacional 0 un nacional de un tercer Estado serán vinculantes para los nuevos Estados miembros en las condiciones previstas en los Tratados originarios y en la presente Acta.

2. Los nuevos Estados miembros se comprometen a adherirse, en las condiciones previstas en la presente Acta, a los acuerdos o convenios celebrados por los Estados miembros de la Comunidad en su composición originaria o ampliada conjuntamente con una de las Comunidades, así como a los acuerdos celebrados por dichos Estados relacionados con tales acuerdos o convenios. La Comunidad y los Estados miembros actuales prestarán, a este respecto, asistencia a los nuevos Estados miembros.

3. Los nuevos Estados miembros se adhieren, por medio de la presente Acta y en las condiciones previstas en ésta, a los acuerdos internos celebrados por los Estados miembros de la Comunidad en su composición originaria o ampliada para la aplicación de los acuerdos 0 convenios contemplados en el apartado 2 .

4. Los nuevos Estados miembros adoptarán las medidas apropiadas para adaptar, en su caso, su posición respecto de las organizaciones internacionales y los acuerdos internacionales, en los que sean igualmente partes otros Estados miembros o una de las Comunidades, a los derechos y obligaciones que resulten de su adhesión a las Comunidades.

Art. 5. El artículo 234 del Tratado CEE y los artículos 105 y 106 del Tratado CEEA serán aplicables, por lo que respecta a los nuevos Estados miembros, a los acuerdos o convenios celebrados antes de su adhesión.

Art. 6. Las disposiciones de la presente Acta no podrán, a menos que ésta disponga otra cosa, ser suspendidas, modificadas 0 derogadas por procedimientos distintos de los previstos en los Tratados originarios para la revisión de dichos Tratados.

Art. 7. Los actos adoptados por las instituciones de las Comunidades a que se refieren las disposiciones transitorias contenidas en la presente Acta conservarán su naturaleza jurídica; en particular, seguirán siendo aplicables los procedimientos para la modificación de tales actos.

Art. 8. Las disposiciones de la presente Acta que tengan por objeto o efecto derogar o modificar, con carácter 
no transitorio, los actos adoptados por las instituciones de las Comunidades tendrán la misma naturaleza jurídica que las disposiciones así derogadas o modificadas y estarán sujetas a las mismas normas que estas uiltimas.

Art. 9. La aplicación de los Tratados originarios y de los actos adoptados por las instituciones estará sujeta, con carácter transitorio, a las excepciones previstas en la presente Acta.

\section{SEGUNDA PARTE}

\section{Adaptaciones de los Tratados}

\section{TITULO PRIMERO}

\section{Disposiciones institucionales}

\section{CAPITULO PRIMERO}

\section{La Asamblea}

Art. 10. El artículo 2 del Acta relativa a la elección de los representantes en la Asamblea por sufragio universal directo aneja a la Decisión 76/787/CECA, CEE, Euratom, será sustituido por las disposiciones siguientes:

«Art. 2. El número de representantes elegidos en cada Estado miembro será el siguiente:

$\begin{array}{ll}\text { Bélgica, 24. } & \text { Irlanda, 15. } \\ \text { Dinamarca, 16. } & \text { Italia, 81. } \\ \text { Alemania, 81. } & \text { Luxemburgo, 6. } \\ \text { Grecia, 24. } & \text { Paises Bajos, 25. } \\ \text { España, 60. } & \text { Portugal, 24. } \\ \text { Francia, 81. } & \text { Reino Unido, 81.» }\end{array}$

\section{CAPITULO II}

\section{El Consejo}

Art. 11. El párrafo segundo del artículo 2 del Tratado por el que se constituye un Consejo único y una Comisión única de las Comunidades
Europeas será sustituido por las disposiciones siguientes:

«La presidencia se ejercerá por rotación por cada Estado miembro en el Consejo durante un período de seis meses según el orden siguiente de los Estados miembros:

- durante un primer ciclo de seis años: Bélgica, Dinamarca, Alemania, Grecia, España, Francia, Irlanda, Italia, Luxemburgo, Paises Bajos, Portugal, Reino Unido;

- durante el ciclo siguiente de seis años: Dinamarca, Bélgica, Grecia, Alemania, Francia, España, Italia, Irlanda, Paises Bajos, Luxemburgo, Reino Unido, Portugal.»

Art. 12. El artículo 28 del Tratado CECA será sustituido por las disposiciones siguientes:

«Art. 28. Cuando el Consejo sea consultado por la Alta Autoridad, deliberará sin proceder necesariamente a una votación. Las actas de las deliberaciones serán transmitidas a la Alta Autoridad.

En los casos en los que el presente Tratado requiere un dictamen conforme del Consejo, el dictamen se considerará adoptado si la propuesta sometida por la Alta Autoridad obtiene el acuerdo:

- de la mayoría absoluta de los representantes de los Estados miembros, incluidos los votos de los representantes de dos de los Estados miembros que aseguren cada uno de ellos al menos una novena parte del valor total de las producciones de carbón y de acero de la Comunidad,

- o, en caso de igualdad de votos y si la Alta Autoridad mantuviere su propuesta tras una segunda deliberación, de los representantes de tres Estados miembros que aseguren cada uno de ellos al menos una novena parte del valor total de las producciones de carbón y de acero de la Comunidad. 
En los casos en los que el presente Tratado requiere una decisión por unanimidad o un dictamen conforme por unanimidad, la decisión o el dictamen se considerarán adoptados si obtienen los votos de todos los miembros del Consejo. No obstante, para la aplicación de los artículos $21,32,32$ bis, 78 sexto y 78 nono del presente Tratado y de los artículos 16, 20, párrafo tercero, 28, párrafo quinto, y 44 del Protocolo sobre el Estatuto del Tribunal de Justicia, las abstenciónes de los miembros presentes o representados no impedirán la adopción de los acuerdos del Consejo que requieran unanimidad.

Las decisiones' del Consejo, distintas de las que requieran mayoria cualificada - unanimidad, serán-tomadas por mayoria de los miembros que componen el Consejo; se considerará que hay mayoria si ésta comprende la mayoría absoluta de los representantes de los Estados miembros, incluidos los votos de los representantes de dos Estados miembros que aseguren cada uno de ellos al menos una novena parte del valor total de las producciones de carbón y de acero de la Comunidad. Sin embargo, para la aplicación de las disposiciones de los artículos 78,78 ter y 78 sexto del presente Tratado que requieren mayoria cualificada, los votos de los miembros del Consejo se ponderarán del . modo siguiente: Bélgica, 5; Dinamarca, 3; Alemania, 10; Grecia, 5; España, 8; Francia, 10; Irlanda, 3; Italia, 10; Luxemburgo, 2; Paises Bajos, 5; Portugal, 5; Reino Unido, 10. Para su adopción, los acuerdos del Consejo requerirán al menos 54 votos, que representen la votación favorable de ocho miembros como minimo.

En caso de votación, cada miembro del Consejo podrá actuar en representación de uno solo de los demás miembros.

El Consejo se relacionará con los Estados miembros por intermedio de su Presidente.

Los acuerdos del Consejo se publicarán en las condiciones que éste determine.»
Art. 13. El párrafo cuarto del artículo 95 del Tratado CECA será sustituido por las disposiciones siguientes:

«Estas modificaciones serán objeto de propuestas elaboradas mediante acuerdo entre la Alta Autoridad y el Consejo, que decidirá por mayoría de diez doceavos de sus miembros, y sometidas al dictamen del Tribunal. En su examen, el Tribunal tendrá plena competencia para apreciar todos los elementos de hecho y de derecho. Si, tras este examen, el Tribunal reconociere la.conformidad de las propuestas con las disposiciones del párrafo precedente, aquéllas serán transmitidas a la Asamblea y entrarán en vigor si fueren aprobadas por mayoria de tres cuartos de los votos emitidos y. por mayoría de dos tercios de los miembros que componen la Asamblea.»

Art. 14. El apartado 2 del artículo 148 del Tratado.CEE y el apartado 2 del artículo 118 del Tratado CEEA serán sustituidos por las disposiciones siguientes:

«2. Cuando el Consejo deba adoptar un acuerdo por mayoria cualificada, los votós de los miembros se ponderarán del modo siguiente:

Bélgica, 5.

Dinamarca, 3.

Alemania, 10.

Grecia, 5.

España, 8.

Francia, 10.

Irlanda, 3.

Italia, 10.

Luxemburgo, 2.

Paises Bajos, 5.

Portugal, 5.

Reino Unido, 10.»

Para su adopción, los acuerdos del Consejo requerirán al menos:

- cincuenta y cuatro votos, cuando en virtud del presente Tratado deban ser adoptados a propuesta de la Comisión,

- cincuenta y cuatro votos, que representen la votación favorable de ocho miembros como mínimo, en los demás casos. 


\section{CAPITULO III \\ LA COMISIÓN}

Art. 15. El párrafo primero del apartado 1 del artículo 10 del Tratado por el que se constituye un Consejo único y una Comisión única de las Comunidades Europeas será sustituido por las disposiciones siguientes:

«l. La Comisión estará compuesta por diecisiete miembros, elegidos en razón de su competencia general y que ofrezcan garantías plenas de independencia.»

Art. 16. El artículo 14 del Tratado por el que se constituye un Consejo único y una Comisión única de las Comunidades Europeas será modificado como sigue:

1) El párrafo primero será sustituido por el texto siguiente:

«El presidente y los seis vicepresidentes de la Comisión serán designados entre los miembros de la misma por un periodo de dos años, con arreglo al mismo procedimiento previsto para el nombramiento de los miembros de la Comisión: Su mandato será renovable.»

2) Se añadirá el párrafo siguiente:

«El Consejo podrá modificar; por unanimidad, las disposiciones relativas a los vicepresidentes.»

\section{CAPITULO IV}

\section{El Tribunal de Justicia}

Art. 17. El párrafo primero del artículo 32 del Tratado CECA, el párrafo primero del artículo 165 del Tratado CEE y el párrafo primero del artículo 137 del Tratado CEEA serán sustituidos por las disposiciones siguientes:

¿El Tribunal de Justicia estará compuesto por trece jueces.»
Art. 18. El párrafo primero del artículo 32 bis del Tratado CECA, el párrafo primero del articulo $166 \mathrm{del}$ Tratado CEE y el párrafo primero del artículo 138 del Tratado CEEA serán sustituidos por las disposiciones siguientes:

«El Tribunal de Justicia estará asistido por seis abogados generales.»

Art. 19. Los párrafos segundo y tercero del artículo 32 ter del Tratado CECA, los párrafos segundo y tercero del artículo 167 del Tratado CEE y los párrafos segundo y tercero del artículo 139 del Tratado CEEA serán sustituidos por las disposiciones siguientes:

«Cada tres años tendrá lugar una renovación parcial de los jueces. Dicha renovación afectará alternativamente a siete y seis jueces.

Cada tres años tendrá lugar una renovación parcial de los abogados generales. Dicha renovación afectará cada vez a tres abogados generales.»

\section{CAPITULO V}

\section{El Tribunal de Cuentas}

Art.20. El apartado 2 del artículo 78 sexto del Tratado CECA, el apartado 2 del artículo 206 del Tratado CEE y el apartado 2 del artículo 180 del Tratado CEEA serán sustituidos por las disposiciones siguientes:

«2. El Tribunal de Cuentas estará compuesto por doce miembros.»

\section{CAPITULO VI}

\section{El Comite ECONOMICo y SOCIAL}

Art. 21. El párrafo primero del artículo 194 del Tratado CEE y el párrafo primero del artículo $166 \mathrm{del}$ Tratado CEEA serán sustituidos por las disposiciones siguientes: 
«El número de miembros del Comité será el siguiente:

$\begin{array}{ll}\text { Bélgica, 12. } & \text { Irlanda, 9. } \\ \text { Dinamarca, 9. } & \text { Italia, 24. } \\ \text { Alemania, 24. } & \text { Luxemburgo, 6. } \\ \text { Grecia, 12. } & \text { Países Bajos, 12. } \\ \text { España, 21. } & \text { Portugal, 12. } \\ \text { Francia, 24. } & \text { Reino Unido, 24.» }\end{array}$

\section{CAPITULO VII}

\section{El Comité Consultivo CECA}

Art. 22. El párrafo primero del artículo 18 del Tratado CECA será sustituido por las disposiciones siguientes:

«Se crea un Comité Consultivo adjunto a la Alta Autoridad. Dicho Comité estará compuesto de un mínimo de sesenta y dos y un máximo de noventa y seis miembros y comprenderá un número igual de productores, trabajadores, consumidores y comerciantes.»

\section{CAPITULO VIII}

\section{El Comite Cientifico y Técnico}

Art. 23. El párrafo primero del apartado 2 del artículo 134 del Tratado CEEA será sustituido por las disposiciones siguientes:

«2. El Comité estará compuesto por trienta y tres miembros, nombrados por el Consejo, previa consulta a la Comisión.»

\section{TITULO II}

\section{Otras adaptaciones}

Art. 24. El apartado 1 del artículo 227 del Tratado CEE será sustituido por las disposiciones siguientes:

«1. El presente Tratado se aplicará al Reino de Bélgica, al Reino de Dinamarca, a la República Federal de Alemania, a la República Helénica, al Reino de España, a la República Francesa, a Irlanda, a la República Italiana, al Gran
Ducado de Luxemburgo, al Reino de los Países Bajos, a la República Portuguesa y al Reino Unido de Gran Bretaña e Irlanda del Norte.»

Art. 25. 1. Tanto los Tratados como los actos de las instituciones de las Comunidades Europeas se aplicarán en las Islas Canarias y en Ceuta y Melilla salvo las excepciones contempladas en los apartados 2 y 3 y en las demás disposiciones de la presente Acta.

2. Las condiciones en que se aplicarán las disposiciones de los Tratados CEE y CECA sobre la libre circulación de mercancias, así como los actos de las instituciones de la Comunidad relativos a la legislación aduanera y a la política comercial en las Islas Canarias y en Ceuta y Melilla, se define en el Protocolo número 2.

3. Sin perjuicio de las disposiciones específicas del artículo 155, los actos de las instituciones de las Comunidades Europeas relativos a la política agrícola común y a la política común de la pesca no se aplicarán en las Islas Canarias y en Ceuta y Melilla.

El Consejo, por mayoria cualificada y a propuesta de la Comisión, determinará las disposiciones de carácter socioestructural que, en el sector de la agricultura, se aplicarán en las Islas Canarias, sin dejar de velar por la compatibilidad de estas disposiciones con los objetivos generales de la política agricola común.

4. A instancia del Reino de España, el Consejo, por unanimidad, a propuesta de la Comisión y previa consulta a la Asamblea, podrá:

- decidir la integración de las Islas Canarias y de Ceuta y Melilla en el territorio aduanero de la Comunidad;

- definir las medidas apropiadas dirigidas a extender a las Islas Canarias y a Ceuta y Melilla las disposiciones vigentes del Derecho Comunitario.

A propuesta de la Comisión, por propia iniciativa o a instancia de un Estado miembro, el Consejo, por unanimidad y 
previa consulta al Parlamento, podrá decidir las adaptaciones del régimen aplicable a las Islas Canarias y a Ceuta y Melilla que resultaren ser necesarias.

\section{TERCERA PARTE}

\section{Adaptaciones de los actos adopta- dos por las instituciones}

Art. 26. Los actos enumerados en la lista que figura en el anexo I de la presente Acta serán objeto de las adaptaciones definidas en dicho anexo.

Art. 27. Las adaptaciones de los actos enumerados en la lista que figura en el anexo II de la presente Acta que resulten necesarias a consecuencia de la adhesión se establecerán de conformidad con las orientaciones definidas en dicho anexo y segun el procedimiento y en las condiciones previstas en el artículo 396.

\section{CUARTA PARTE \\ Medidas transitorias \\ TITULO PRIMERO}

\section{Disposiciones institucionales}

Art. 28. 1. En el transcurso de los dos primeros años siguientes a la adhesión, cada uno de los nuevos Estados miembros procederá a la elección, por sufragio universal directo, de los sesenta representantes del pueblo español en la Asamblea y de los veinticuatro representantes del pueblo portugués en la Asamblea, respectivamente, de conformidad con las disposiciones del Acta, de 20 de septiembre de 1976, relativa a la elección de los representantes en la Asamblea por sufragio universal directo.

El mandato de dichos representantes expirará al mismo tiempo que el de los representantes elegidos en los Estados miembros actuales para el periodo quinquenal en curso.

2. Desde el momento de la adhesión y para el periodo que transcurra hasta cada una de las elecciones mencionadas en el apartado 1, los representantes de los pueblos español y portugués en la Asamblea serán designados por los Parlamentos de los nuevos Estados miembros de entre sus miembros, de acuerdo con el procedimiento fijado por cada uno de estos Estados.

Art. 29. A efectos de aplicación del párrafo segundo del artículo 2 del Tratado por el que se constituye un Consejo único y una Comisión única de las Comunidades Europeas, el nuevo orden de los Estados miembros que se fija en el artículo 11 de la presente Acta se aplicará al têrmino de los periodos de rotación que faltan por cubrir con arreglo al orden de los Estados miembros fijado en el citado artículo 2 en su texto vigente antes de la adhesión.

\section{TITULO II}

Medidas transitorias relativas a España

\section{CAPITULO PRIMERO \\ LIBRE CIRCULACIÓN DE MERCANCIAS}

\section{Sección I.-Disposiciones arancelarias}

Art. 30. 1. Para cada producto, el derecho de base sobre el cual se operarán las reducciones sucesivas previstas en el artículo 31, en el apartado 1 del artículo 75 y en los apartados 1 y 2 del artículo 173 será el derecho efectivamente aplicado el 1 de enero de 1985 a los productos originarios de la Comunidad en su composición actual y de España en el marco de sus intercambios.

2. Para cada producto, el derecho de base que se tendrá en cuenta para las aproximaciones al arancel aduanero común y al arancel unificado CECA previstas en el articulo 37, en el apartado 2 del artículo 75 y en el apartado 4 del artículo 173 serả el derecho efectivamente aplicado por el Reino de España el 1 de enero de 1985.

3. Sin embargo, si con posterioridad a esta fecha y antes de la adhesión se aplicare una reducción arancelaria, se considerará derecho de base el derecho así reducido. 
DA-1985-1986, núms. 206-207. Acta relativa a laș condiciones de Adhesión dẹ Reino de Espa...

4. La Comunidad en su composición actual y el Reino de España se comunicarán sus derechos de base respectivos.

5. No obstante lo dispuesto en el apartado 1, para los productos que se mencionan a continuación, los derechos de base sobre los cuales el Reino de España operará las reducciones sucesivas previstas en el articulo 31 serán los que se indican frente a cada uno de esos productos.

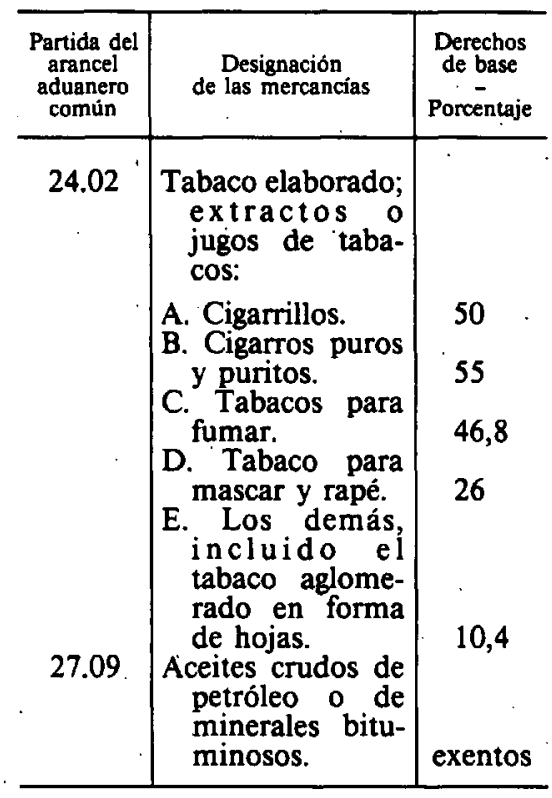

Art. 31. 1. Los derechos de aduana de importación entre la Comunidad en su composición actual y el Reino de España serán suprimidos progresivamente según el siguiente ritmo:

- El 1 de marzo de 1986, cada derecho quedará reducido al 90 por 100 del derecho de base:

- El 1 de enero de 1987, cada derecho quedará reducido al 77,5 por 100 del derecho de base.

- El 1 de enero de 1988, cada derecho quedará reducido al 62,5 por 100 del derecho de base.

- El 1 de enero de 1989, cada derecho quedará reducido al 47,5 por 100 del derecho de base.

- El 1 de enero de 1990, cada derecho quedará reducido al 35,0 por 100 del derecho de base.

- El 1 de enero de 1991 , cada derecho quedará reducido al 22,5 por $100 \mathrm{del}$ derecho de base.

- El 1 de enero de 1992, cada derecho quedará reducido al 10,0 por $100 \mathrm{del}$ derecho de base.

- La última reducción del 10 por 100 se efectuará el 1 de enero de 1993.

2. No obstante lo dispuesto en el apartado 1, a partir del 1 de marzo de 1986 quedarán exentas de derechos de aduana:

a) Las importaciones que se beneficien de las disposiciones relativas a la franquicia fiscal en el ámbito del tráfico de viajeros entre los Estados miembros;

b) Las importaciones de mercancias en pequeños envios, sin carácter comercial, que se beneficien de las disposiciones relativas a la franquicia fiscal entre los Estados miembros.

3. Los tipos de los derechos calculados conforme al apartado 1 se aplicarán redondeando el primer decimal con abandono del segundo.

Art. 32. En ningún caso se aplicarán dentro de la Comunidad derechos de aduana superiores a los que se apliquen respecto de los terceros paises que se beneficien de la cláusula de nación más favorecida.

En caso de modificación o de suspensión de los derechos del arancel aduanero común o de aplicación por el Reino de España del artículo $\cdot 40$, el Consejo, por mayoria cualificada y a propuesta de la Comisión, podrá adoptar las medidas necesarias para mentener la preferencia comunitaria.

En caso de modificación o de suspensión de los derechos del arancel unificado CECA o de aplicación por el Reino de España del artículo 40, la Comisión 
J podrá adoptar las medidas necesarias para mantener la preferencia comunitaria.

Art. 33. El Reino de España podrá suspender total o parcialmente la percepción de los derechos aplicables a los productós importados de la Comunidad en su composición actual. Informará de ello a los demás Estados miembros y a la Comisión.

El Consejo, por mayoria cualificada y a propuesta de la Comisión, podrá suspender total o parcialmente la percepción de los derechos aplicables a los productos importados de España.

Art. 34. Desde el momento de la adhesión se suprimirán para los automóviles importados de la Comunidad en su composición actual los contingentes arancelarios de derecho reducido, resultantes del artículo 30, para la importación en España de determinados vehículos automóviles de turismo nuevos de la subpartida ex 87.02 A I b) del arancel aduanero común.

A partir del 1 de enero de 1986, el Reino de España abrirá contingentes arancelarios anuales de derecho reducido para la importación de vehículos automóviles para el transporte de personas, con motor de explosión o de combustión interna, que no sean autocares ni aurobuses, de la subpartida 87.02 A I b) del arancel aduanero común, originanos de la Comunidad en su composición actual. La inclusión de tales vehículos automóviles en esos contingentes arancelarios se regirá por lo dispuesto en el Protocolo número 6.

Art. 35. Las exacciones de efecto equivalente a los derechos de aduana de importación existentes en los intercambios entre la Comunidad en su composición actual y España serán suprimidas el 1 de marzo de 1986.

Ningún derecho de aduana de carácter fiscal será aplicable a partir del 1 de marzo de 1986.

Art. 36. Los derechos de aduana de exportación y las exacciones de efecto equivalente existentes en los intercambios entre la Comunidad en su composi- ción actual y España serán suprimidos el 1 de marzo de 1986.

Art. 37. 1. A fin de introducir progresivamente el arancel aduanero común y el arancel unificado CECA, el Reino de España modificará su arancel aplicable a terceros países del modo siguiente:

A partir del 1' de marzo de 1986:

a) Para las partidas arancelarias respecto de las cuales los derechos de base no difieran en más de un 15 por 100 por encima o por debajo de los derechos del arancel aduanero común o del arancel unificado CECA, se aplicarán estos últimos derechos;

b) En los demás casos, el Reino de España aplicará un derecho que reduzca la diferencia entre los derechos de base y los derechos del arancel aduanero común 0 los del arancel unificado CECA según el ritmo siguiente:

- El 1 de marzo de 1986: reducción del 10 por 100 .

- El 1 de enero de 1987: reducción del 12,5 por 100.

- El 1 de enero de 1988: reducción del 15 por 100.

- El l de enero de 1989: reducción del 15 por 100.

- El 1 de enero de 1990: reducción del 12,5 por 100 .

- El 1 de enero de 1991: reducción del 12,5 por 100 .

- El 1 de enero de 1992: reducción del 12,5 por 100 .

El Reino de España aplicará integramente el arancel aduanero común y el arancel unificado CECA a partir del 1 de enero de ' 1993.

2. No obstante lo dispuesto en el apartado 1, para los productos enumerados en el Anexo del Acuerdo sobre el comercio de aeronaves civiles celebrado en el marco de las negociaciones comerciales de 1973-1979 del Acuerdo General sobre Aranceles y Comercio, el Reino de España àplicará íntegramente el arancel aduanero común a partir del 1 de marzo de 1986. 
Art. 38. Los derechos autónomos incluidos en el arancel aduanero común de la Comunidad serán los derechos autónomos de la Comunidad en su composición actual.

Los derechos convencionales del arancel aduanero común de la CEE y del arancel unificado CECA serán los derechos convencionales de la CEE y de la CECA en su composición actual con la excepción de los ajustes que se afectuarán para tener en cuenta el hecho de que los derechos en vigor en los aranceles español y portugués son, en su conjunto, más elevados que los derechos en vigor en los aranceles de la CEE y de la CECA en su composición actual.

Este ajuste, que será objeto de negociaciones en el marco del Acuerdo General sobre Aranceles y Comercio, seguirá dentro de los límites de las posibilidades abiertas por el artículo XXIV de dicho Acuerdo.

Art. 39. 1. Cuando los derechos del arancel aduanero del Reino . de España sean de naturaleza distinta a la de los derechos correspondientes del arancel aduanero común o del arancel unificado CECA, la aproximación progresiva de los primeros a los segundos se efectuará adicionando los elementos del derecho de base español a los del derecho del arancel aduanero común o a los del arancel unificado CECA, reduciéndose progresivamente a cero el derecho de base español, según el ritmo previsto en el artículo 37 y en el apartado 2 del artículo 75 y aumentándose el derecho del arancel aduanero común o del arancel unificado CECA de cero hasta alcanzar, progresivamente, y según el mismo ritmo, su importe final.

2. A partir del 1 de marzo de 1986, si determinados derechos del arancel aduanero común o del arancel unificado CECA fueren modificados o suspendidos, el Reino de España modificará o suspenderá simultáneamente su arancel en las proporciones que resulten de la aplicación del artículo 37 .

3. El Reino de España aplicará, a partir del 1. de marzo de 1986, la nomen- clatura del arancel aduanero común y la del arancel unificado CECA.

El Reino de España podrá incluir en estas nomenclaturas las subdivisiones nacionales existentes en el momento de la adhesión que sean indispensables para que la aproximación progresiva de sus derechos de aduana a los del arancel aduanero común y a los del arancel unificado CECA se efectúe en las condiciones previstas en la presente Acta.

En caso de modificación de la nomenclatura del arancel aduanero común o del arancel unificado CECA para los productos contemplados en la presente Acta, el Consejo, por mayoría cualificada y a propuesta de la Comisión, podrá adaptar la nomenclatura de estos productos, tal como figura en la presente Acta.

4. Con vistas a la aplicación del apartado 3 y para facilitar la progresiva introducción por el Reino de España del arancel aduanero común, del arancel unificado CECA y de la progresiva supresión de los derechos de aduana entre la Comunidad en su composición actual y el Reino de España, la Comisión determinará, si procede, las modalidades de aplicación según las cuales el Reino de España modíficará sus derechos de aduana, sin que estas modalidades puedan implicar modificación alguna de los artículos 31 y 37 .

5. Los tipos de los derechos calculados conforme al artículo 37 se aplicarán redondeando el primer decimal.

Los redondeos se harán con abandono del segundo decimal cuando los derechos españoles se aproximen a derechos del arancel aduanero común o del arancel unificado CECA inferiores a los derechos de base españoles. En los demás casos, los redondeos se realizarán aplicando la cifra decimal superior.

Art. 40. Con objeto de acomodar su arancel al arancel aduanero común y al arancel unificado CECA, el Reino de España tendrá libertad para modificar sus derechos de aduana a un ritmo más rápido que el previsto en el artículo 37. Informará de ello a los demás Estados miembros y a la Comisión. 
Art. 41. Durante el periodo de supresión de los derechos de aduana entre la Comunidad en su composición actual y el Reino de España y durante el período de aproximación de los derechos del arancel aduanero español a los del arancel aduanero común y del arancel unificado CECA, el Reino de España tendrá la facultad de abrir, respecto de los terceros países, los contingentes arancelarios efectivamente establecidos el 1 de enero de 1985 .

De abrirse tales contingentes, se aplicará el artículo 37, durante el período de apertura de dichos contingentes, para determinar los derechos aplicables a los productos importados de los terceros países, limitándose las cantidades 0 valores para los que se conceda el beneficio de estos derechos a los volúmenes efectivamente importados en el marco de esos mismos contingentes que se encuentren abiertos el 1 de enero de 1985. Los productos importados de la Comunidad en su composición actual se beneficiarán de los derechos reducidos según las disposiciones del artículo 31, sin limitación de cantidad o de valor, durante el periodo de apertura de dichos contingentes.

"De no abrirse tales contingentes, el Reino de España aplicará a los productos importados de la Comunidad en su composición actual los derechos aplicables en caso de apertura de dichos contingentes. Las cantidades o valores que podrán beneficiarse de estos derechos se limitarán a los volúmenes efectivamente importados de la Comunidad en su composición actual en el marco de esos mismos contingentes abiertos el 1 de enero de 1985.

Sección II.-Supresion de las restricciones cuantitativas $y$ de las medidas de efecto equivalente

Art. 42. ' Las restricciones cuantitativas a la importación y a la exportación, así como cualquier medida de efecto equivalente existente entre la Comunidád en su composición actual y el Reino de España, serán suprimidas el 1 de enero de 1986.

Art. 43. 1. No obstante 10 dispuesto en el artículo 42, el Reino de España podrá seguir sometiendo a restricciones cuantitativas a la importación:

- Hasta el 31 de diciembre de 1988, los productos mencionados en el Anexo III.

- Hasta el 31 de diciembre de 1989, los productos mencionados en el Anexo IV.

2. Las restricciones, contempladas en el apartado 1 revestirán la forma de contingentes.

3. Los contingentes para el año 1986 se recogen respectivamente en el Anexo III y en el Anexo IV.

El porcentaje de aumento progresivo de los contingentes contemplados en el Anexo III y de los contingentes números 1 a 5 y 10 a 14 contemplados en el Anexo IV será del 25 por 100 al comienzo de cada año en lo concerniente a los contingentes expresados en ECUS y del 20 por 100 al comienzo de cada año por lo que respecta a los contingentes expresados en volumen. Este aumento se añadirá a cada contingente y el aumento siguiente se calculará partiendo de la cifra total obtenida.

Para los contingentes números 6 a 9 que figuran en el anexo IV, el porcentaje anual de aumento progresivo será el siguiente:

Primer año: 13 por 100 .

Segundo año: 18 por 100 .

Tercer año: 20 por 100 .

Cuarto año: 20 por 100 .

4. Cuando la Comisión haga constar por medio de una decisión que las importaciones en España de uno de los productos mencionados en los Anexos III y IV han sido, durante dos años consecutivos, inferiores al 90 por 100 del contingente fijado, se liberará la importación de dicho producto procedente de los Estados miembros actuales desde el comienzo del año que siga a esos dos años. 
5. El Procotolo número 7 define los principios que aplicará el Reino de España para la gestión de los contingentes previstos en el apartado 2 del presente artículo.

Art. 44. 1. No obstante lo dispuesto en el artículo 42, el Reino de España podrá mantener, hasta el 31 de diciembre de 1989 , un porcentaje de incorporación nacional que no supere el 60 por 100 , para las partes, piezas sueltas y accesorios utilizados en la fabricación de vehículos automóviles para el transporte de personas como motor de exṕlosión o de combustión interna, distintos de los autocares y los autobuses de la subpartida 87.02 A I b) del arancel aduanero común.

2. El porcentaje de incorporación nacional previsto en el apartado 1 será idéntico para los fabricantes nacionales de los demás Estados miembros establecidos en España y para todos los fabricantes nacionales del Reino de España. El trato concedido a los fabricantes antes mencionados no será menos favorable que el concedido a. los fabricantes de los terceros paises.

Art. 45. 1. No obstante 10 dispuesto en el artículo 42, la Comunidad podrá mantener, hasta el 31 de diciembre de 1988, restricciones cuantitativas a la exportación a España de los productos siguientes:

\begin{tabular}{|c|c|}
\hline $\begin{array}{l}\text { Partida } \\
\text { del arancel } \\
\text { aduanero } \\
\text { comun }\end{array}$ & $\begin{array}{l}\text { Designación } \\
\text { de las mercancias }\end{array}$ \\
\hline ex 26.03 & $\begin{array}{l}\text { Cenizas y residuos de } \\
\text { cobre y de sus aleacio- }\end{array}$ \\
\hline ex 74.01 & $\begin{array}{l}\text { Desperdicios y desechos } \\
\text { de cobre y de sus alea- } \\
\text { ciones. }\end{array}$ \\
\hline
\end{tabular}

2. Las restricciones contempladas en el apartado 1 revestirán la forma de contingentes cuantitativos anuales:

3. Los contingentes para el año 1986 serán, respectivamente, de 5.000 tonela- das para las cenizas y residuos de cobre y de sus aleaciones de la partida ex 26.03 del arancel aduanero común y de 14.000 toneladas para los desperdicios y desechos de cobre y de sus aleaciones de la partida ex 74.01 del arancel aduanero común.

El porcentaje de aumento progresivo $y$ anual de los contingentes iniciales, aplicable a partir del comienzo del segundo año, será del 10 por 100 al comienzo de cada año. Este aumento se añadirá a cada contingente y el aumento siguiente se calculará partiendo de la cifra total obtenida.

4. Cuando las exportaciones de la Comunidad de uno de los productos mencionados en el apartado 1 hayan sido, durante los años 1986 y 1987 , inferiores al 90 por 100 del contigente abierto, las restricciones antes referidas serán suprimidas el 1 de enero de 1988.

5. El régimen aplicado por la Comunidad con respecto a España, tal y como se prevé en los apartados 1 a 4, no será menos favorable que el aplicado respecto de los terceros paises.

Art. 46. No obstante lo dispuesto en el artículo 42, los Estados miembros actuales podrán mantener, hasta el final del periodo contemplado en el artículo 52 , las restricciones cuantitativas a la exportación de chatarras, desperdicios y desechos de fundición, de hierro o de acero de la partida 73.03 del arancel aduanero común, que aplicaban respecto del Reino de España con anterioridad a la fecha de la adhesión, siempre que este régimen no sea más restrictivo que el aplicado a las exportaciones a los terceros países.

Art. 47. 1. No obstante 10 dispuesto en el artículo 42, el titular, o su derechohabiente, de una patente relativa a un producto químico, farmacéutico o fitosanitario, registrada en un Estado miembro en una fecha en la que una patente de producto no podía obtenerse en España para este mismo producto, podrá invocar el derecho que le confiere esa patente para impedir la importación y la comercialización de 
$J$ dicho producto en el Estado o Estados miembros actuales donde este producto esté protegido por una patente, incluso si dicho producto ha sido comercializado por primera vez en España por el mismo titular o con su consentimiento.

2. Este derecho podrá invocarse, respecto de los productos mencionados en el apartado 1, hasta el final del tercer año después de la introducción por parte de España de la patentabilidad de estos productos.

Art. 48. 1. Sin perjuicio de lo dispuesto en los apartados 2 y 3 del presente artículo, el Reino de España adecuará progresivamente, desde el 1 de enero de 1986, los monopolios nacionales de carácter comercial, definidos en el apartado 1 del artículo 37 del Tratado CEE, teniendo en cuenta, en su caso; el apartado 2 del artículo 90 del Tratado CEE, de tal modo que, a más tardar, el 31 de diciembre de 1991, quede asegurada la exclusión de toda discriminación entre los nacionales de los Estados miembros respecto de las condiciones de abastecimiento y de mercado.

Los Estados miembros actuales asumirán, respecto del Reino de España, obligaciones equivalentes.

La Comisión formulará recomendaciones sobre las modalidades y el ritmo según los cuales deberá realizarse la adaptación, quedando entendido que estas modalidades y este ritmo deberán ser los mismos para el Reino de España que para los Estados miembros actuales.

2. El Reino de España suprimirá. desde el 1 de enero de 1986, la totalidad de los derechos exclusivos de exportación.

3. En lo que se refiere a los productos incluidos en la lista que figura en el Anexo $\mathrm{V}$, los derechos exclusivos de importación se suprimirán, a más tardar, el 31 de diciembre de 1991: La supresión de estos derechos exclușivos se realizará mediante la apertura progresiva, a partir del 1 de enero de 1986, de contingentes de importación para los productos procedentes de los Estados miembros actuales. Los volúmenes de los contingentes para el año 1986 se indican en dicha lista.

El Reino de España aumentará los volúmenes de los contingentes en las condiciones indicadas en el anexo contemplado en el párrafo primero.

Los aumentos expresados en porcentajes se añadirán a cada contigente y el aumento siguiente se calculará partiendo de la cifra total obtenida.

Los contingentes mencionados en el párrafo primero estarán abiertos a todos los operadores sin restricción y los productos importados en el marco de dichos contingentes no podrán ser sometidos en España a derechos exclusivos de comercialización en la fase del comercio al por mayor; en lo que respecta a la venta al por menor de determinados productos importados dentro de los contingentes, deberá asegurarse la venta de dichos productos a los consumidores en forma no discriminatoria.

4. La adecuación del monopolio de los productos incluidos en la lista que figura en el Anexo VI podrá no afectar al funcionamiento del monopolio español del petróleo respecto de los terceros países. Este monopolio podrá seguir fijando el origen y las condiciones de adquisición de una cuota de las importaciones de petróleo bruto, procedente de los terceros paises, necesarias para garantizar la seguridad del abastecimiento del mercado español, respetando las disposiciones del Tratado CEE y, en particular, las relativas a la libre circulación contenidas en los artículos 30 y 37 del mismo Tratado.

Art. 49. No obstante lo dispuesto en el artículo 42, el régimen defínido en el Protocolo número 9 se aplicará respecto de las exportaciones a la Comunidad en su composición actual de productos textiles procedentes de España.

\section{Sección III.-Otras disposiciones}

Art. 50. 1. La Comisión determinará, tomando debidamente en cuenta las disposiciones vigentes y, en especial, las relativas al tránsito comunitario, los 
métodos de cooperación administrativa destinados a asegurar que las mercancías que reúnan las condiciones requeridas a tal fin se beneficien de la supresión de los derechos de aduana y exacciones de efecto equivalente, asi como de las restricciones cuantitativas y medidas de efecto equivalente previstas en la presente Acta.

2. Hasta el 28 de febrero de 1986, las disposiciones del Acuerdo de 1970 entre la Comunidad Económica Europea y España relativas al régimen aduanero seguirán siendo aplicables a los intercambios entre la Comunidad en su composición actual y España.

3. La Comisión determinará las disposiciones aplicables a partir del 1 de marzo de 1986 a los intercambios, dentro de la Comunidad, de mercancias obtenidas en la Comunidad en cuya fabricación se hayan empleado:

- Productos que no hayan estado sujetos a los derechos de aduana y. exacciones de efecto equivalente que les eran aplicables en la Comunidad en su composición actual o en España, o que se hayan beneficiado de una devolución total o parcial de los mismos.

- Productos agricolas que no satisfagan las condiciones requeridas para ser admitidos a la libre circulación en la Comunidad en su composición actual o en España

Al adoptar tales disposiciones, la Comisión tendrá en cuenta las normas previstas en la presente Acta para la supresión de los derechos de aduana entre la Comunidad en su composición actual y España y para la aplicación progresiva, por el Reino de España, del arancel aduanero común y de las disposiciones relativas a la política agricola común.

Art. 51. 1. Salvo disposición en contrario de la presente Acta, las disposiciones vigentes en materia de legislación aduanera para los intercambios con los terceros paises se aplicarán en las mismas condiciones a los intercambios dentro de la Comunidad, mientras se sigan percibiendo derechos de aduana en tales intercambios.

Para la determinación del valor en aduana respecto de los intercambios dentro de la Comunidad, así como de los intercambios con los terceros países, hasta el:

- 31 de diciemibre de 1992 para los productos industriales, $y$

- 31 de diciembre de 1995 para los productos agrícolas,

el territorio aduanero que deberá tomarse ên cuenta será el definido en las disposiciones existentes en la Comunidad y en el Reino de España el 31 de diciembre de 1985 .

2. El Reino de España aplicará, desde el 1 de marzo de 1986, la nomenclatura del arancel aduanero común y la del arancel unificado CECA en los intercambios dentro de la Comunidad.

El Reino de España podrá incluir en estas nomenclaturas las subdivisiones nacionales existentes en el momento de la adhesión que sean indispensables para que la supresión progresiva de sus derechos de aduana dentro de la Comunidad se efectue en las condiciones previstas en la presente Acta.

Art. 52. Durante un periodo de tres años a partir de la adhesión, el Reino de España completará la reestructuración de su industria siderúrgica en las condiciones definidas en el Protocolo número 10.

La Comisión, previo dictamen conforme del Consejo, podrá reducir el período antes mencionado y modificar las modalidades establecidas en dicho Protocolo en función:

- del desarrollo de los planes de reestructuración españoles, habida cuenta de los factores significativos del restablecimiento de la viabilidad de las empresas;

- de las medidas siderúrgicas en vigor en la Comunidad después de la adhesión; en este caso, el régimen aplicable después de la adhesión a los suministros españoles a la Comunidad en su composición actual no deberia dar 
lugar a diferencias fundamentales de trato entre España y los otros Estados miembros.

Art. 53. 1. En caso de que los montantes compensatorios contemplados en el artículo 72 sean aplicados en los intercambios entre la Comunidad en su composición actual y el Reino de España, a uno o varios de los productos de base que se considere que han sido utilizados para la fabricación de las mercancias a que se refiere el Reglamento (CEE) número 3033/80 del Consejo, de 11 de noviembre de 1980, por el que se determina el régimen de intercambios aplicable a determinadas mercancias que resultan de la transformación de productos agrícolas, se aplicarán las siguientes medidas transitorias:

- se aplicará un montante compensatorio, calculado sobre la base de los montantes compensatorios contemplados en el artículo 72 y según las normas previstas en el Reglamento (CEE) número 3033/80 para el cálculo del elemento móvil aplicable a las mercancias a que se refiere este Reglamento, en el momento de la importación en la Comunidad en su composición actual de dichas mercancias procedentes de España;

- cuando las mercancías a que se refiere el Reglamento (CEE) número 3033/80 procedentes de terceros países sean importadas en España, el elemento móvil fijado en este Reglamento será aumentado o disminuido, según los casos, en la cuantía del montante compensatorio contemplado en el primer guión;

- se aplicará un montante compensatorio, determinado sobre la base de los montantes compensatorios fijados para los productos de base y según las normas aplicables para el cálculo de las restituciones previstas en el Reglamento (CEE) número 3035/80, del Consejo, de 11 de noviembre de 1980 , por el que se establecen, para determinados productos agricolas exportados en forma de mercancias no compren- didas en el Anexo II del Tratado, las normas generales relativas a la concesión de restituciones a la exportación y los criterios para la determinación de su importe, en el caso de las mercancias a que se refiere dicho Reglamento, en el momento de la exportación a España de estas mercancias procedentes de la Comunidad en su composición actual;

- cuando los productos a que se refiere el Reglamento (CEE) número 3035/80 sean exportados de España a terceros paises, serán sometidos al montante compensatorio contemplado en el guión tercero.

2. El derecho de aduana que constituya el elemento fijo del gravamen aplicable, en el momento de la adhesión, sobre la importación en España de las mercancias a que se refiere el Reglamento (CEE) número $3033 / 80$, se determinará deduciendo del derecho de aduana de base aplicado por el Reino de España a los productos originarios de la Comunidad en su composición actual, un elemento móvil igual al elemento móvil fijado en aplicación del Reglamento (CEE) número 3033/80, aumentado o disminuido, según los casos, en la cuantia del montante compensatorio contemplado en los guiones primero y tercero del apartado 1.

Para los productos de las partidas del arancel aduanero común mencionados en el Anexo VII, el elemento fijo será igual a los derechos de base que figuran en el mencionado Anexo.

España podrá someter los productos incluidos en el Anexo VII así como las bebidas espirituosas de la $v$ subpartida $22.09 \mathrm{C}$ del arancel aduanero común, a una vigilancia comunitaria, durante un periodo de transición de siete años, con fines exclusivamente estadísticos. En cualquier caso la importación de dichos productos no podrá sufrir ningún retraso como consecuencia de la aplicación de esta vigilancia estadística.

3. El derecho de aduana que constituya el elemento fijo del gravamen aplicable, en el momento de la adhesión, a 
la importación en España de las mercancias a que se refiere el Reglamento (CEE) número $3033 / 80$, procedentes de terceros países, será igual al más alto de los dos montantes determinados como sigue:

- el montante obtenido al deducir del derecho de aduana de base aplicable por el Reino de España a las importaciones procedentes de los terceros países, un elemento móvil igual al elemento móvil fijado en aplicación del Reglamento (CEE) número 3033/80, aumentado o disminuido, según sea el caso, con el importe del montante compensatorio contemplado en los guiones $1 .^{\circ}$ y $3 .^{\circ}$ del apartado 1 ;

- el montante obtenido.al sumar el elemento fijo aplicable a las importaciones en España procedentes de la Comunidad en su composión actual y el elemento fijo del derecho del arancel aduanero común ( 0 , con relación a los terceros países que se benefician del sistema comunitario de preferencias generalizadas, el elemento fijo preferencial que la Comunidad aplique, llegado el caso, a las importaciones procedentes de dichos países).

4. No obstante lo dispuesto en el artículo 30 , los derechos de aduana aplicados por el Reino de España a las importaciones procedentes de la Comunidad y de los terceros países se convertirán, en el momento de la adhesión, en el tipo de derecho y las unidades incluidos en el arancel aduanero común. La conversión se operará sobre la base del valor de las mercancias importadas en España durante los cuatro últimos trimestres de los que se disponga de información 0 , a falta de importación de las correspondientes mercancías en España, sobre la base del valor unitario de estas mismas mercancias importadas en la Comunidad en su composición actual.

5. Cada elemento fijo aplicado en los intercambios entre la Comunidad en su composición actual y el Reino de España se suprimirá con arreglo al artículo 31.
Cada elemento fijo aplicado por el Reino de España a la importación procedente de los terceros países se aproximará al elemento fijo del derecho del arancel aduanero común (o, llegado el caso, al elemento fijo preferencial previsto por el sistema comunitario de preferencias generalizadas), con arreglo a los artículos 37 y 40 .

6. En caso de que una reducción del elemento móvil del derecho del arancel aduanero común sea concedido a los terceros países que se benefician del sistema comunitario de preferencias generalizadas, el Reino de España aplicará este elemento móvil preferencial desde el momento de la adhesión.

Sección IV.-Intercambio entre el Reino de España y la Repuiblica Portuguesa

Art. 54. El Reino de España aplicará en sus intercambios con la República Portuguesa los artículos 30 a 53, salvo lo dispuesto en las condiciones definidas en el Protocolo número 3.

\section{CAPITULO II}

\section{LIBRE CIRCULACIÓN DE PERSONAS, SERVICIOS Y CAPITALES}

\section{Sección I.-Trabajadores}

Art. 55. El artículo 48 del Tratado CEE sólo será aplicable, respecto de la libre circulación de los trabajadores entre España y los demás Estados miembros, salvo lo establecido en las disposiciones transitorias previstas en los artículos 56 a 59 de la presente Acta.

Art. 56. 1. Los artículos 1 a 6 del Reglamento (CEE) número 1612/68 relativo a la libre circulación de los trabajadores dentro de la Comunidad sólo serán aplicables en España, respecto de los nacionales de los demás Estados miembros, y en los demás Estados miembros, respecto de los nacionales españoles, a partir de 1 de enero de 1993.

El Reino de España y los demás - Estados miembros tendrá la facultad de mantener en vigor hasta el 31 de diciembre de 1992, respectivamente, en rela- 
J ción con los nacionales de los demás Estados miembros, por una parte, y los nacionales españoles, por otra, las disposiciones nacionales o que resulten de acuerdos bilaterales que sometan a previa autorización la inmigración con miras a ejercer un trabajo por cuenta ajena $y / 0$ el acceso a un empleo por cuenta ajena.

Sin embargo, el Reino de España y el Gran Ducado de Luxemburgo tendrán la facultad de mantener en vigor hasta el 31 de diciembre de 1995. las disposiciones nacionales contempladas en el párrafo precedente, respectivamente, en relación con los nacionales luxemburgueses, por una parte, y los nacionales españoles, por otra.

2. A partir de 1 de enero de 1991, el Consejo, previo informe de la Comisión, examinará el resultado de la aplicación de las medidas excepcionales contempladas en el apartado 1 .

Al término de este examen, el Consejo, por unanimidad y a propuesta de la Comisión, podrá adoptar, sobre la base de nuevos datos, disposiciones para la adaptación de dichas medidas.

Art. 57. 1. Hasta el 31 de diciembre de 1990, el artículo 11 del Reglamento (CEE) número 1612/68 será aplicable en España, respecto de los nacionales de los demás Estados miembros, y en los demás Estados miembros, respecto de los nacionales españoles, en las condiciones que se indican a continuación:

a) Los miembros de la familia del trabajador mencionados en la letra a) del apartado 1 del artículo 10 de dicho Reglamento, regularmente instalados con él en el territorio de un Estado miembro, en la fecha de la firma de la presente Acta tendrán derecho, desde el momento de la adhesión, a acceder a cualquier actividad asalariada en el territorio de ese Estado miembro.

No obstante, el beneficio de dicho derecho podrá ser limitado a los miembros de la familia de trabajadores españoles que estén instalados en otro Estado miembro en una fecha anterior, fijada en virtud de acuerdos especiales bilaterales celebrados antes de la fecha de la firma de la presente Acta y que se refieran a las condiciones de acceso al mercado de trabajo de los miembros de la familia de los trabajadores españoles después de la adhesión.

b) Los miembros de la familia del trabajador mencionados en la letra a) del apartado 1 del artículo 10 de dicho Reglamento, regularmente instalados con él en el territorio de un Estado miembro después de la fecha de la firma de la presente Acta, tendrán derecho de acceder a cualquier actividad asalariada si han residido en el territorio de dicho Estado desde hacía tres años por lo menos. Dicho plazo de residencia quedará reducido a dieciocho meses a partir de 1 de enero de 1989.

El presente apartado se entenderá sin perjuicio de las disposiciones nacionales o que resulten de acuerdos bilaterales más favorables.

2. El régimen previsto en el apartado 1 será igualmente aplicable a los miembros de la familia del trabajador independiente instalados con él en un Estado miembro.

Art. 58. En la medida en que determinadas disposiciones de la Directiva $68 / 360 / C E E$ relativa a la supresión de las restricciones al desplazamiento y a la estancia de los trabajadores de los Estados miembros y de sus familias dentro de la Comunidad sean indisociables de las del Reglamento (CEE) número $1612 / 68$, cuya aplicación ha sido aplazada en virtud del artículo 56, el Reino de España, por una parte, y los demás Estados miembros, por otra, tendrán la facultad de apartarse de estas disposiciones en la medida necesaria para la aplicación de las excepciones previstas en el artículo 56 en relación con dicho Reglamento.

Art. 59. El Reino de España y los demás Estados miembros adoptarán, con la ayuda de la Comisión, las medidas necesarias para que pueda hacerse extensiva a España, a más tardar, el 1 de enero de 1993, la aplicación de la Deci- 
sión de la Comisión de 8 de diciembre de 1972 relativa al sistema uniformado establecido en aplicación del artículo 15 del Reglamento (CEE) número 1612/68 del Consejo, denominado sistema «Sedoc», y de la Decisión de la Comisión de 14 de diciembre de 1972 relativa al «esquema comunitario» para la recopilación y la difusión de las informaciones previstas en el apartado 3 del artículo 14 del Reglamento (CEE) número 1612/68 del Consejo.

Art. 60. 1. Hasta la entrada en vigor de la solución uniforme para todos los Estados miembros contemplados en el artículo 99 del Reglamento (CEE) número $1408 / 71$ relativo a la aplicación de los regímenes de seguridad social a los trabajadores por cuenta ajena y a los trabajadores por. cuenta propia y a los miembros de su familia que se desplacen dentro de la Comunidad y a más tardar hasta el 31 de diciembre de 1988, los apartados 1 y 3 del artículo 73, el apartado 1 del articulo 74 y el apartado 1 del articulo 75 del Reglamento (CEE) número $1408 / 71$, así como los artículos 86 y 88 del Reglamento (CEE) número $574 / 72$ por el que se establecen las modalidades de aplicación del Reglamento (CEE) número 1408/71, no serán aplicables a los trabajadores españoles ocupados en un Estado miembro que no sea España, los miembros de cuya familia residan en España.

El apartado 2 del artículo 73, el apartado 2 del artículo 74, el apartado 2 del artículo 75 y el apartado 9 del artículo 94 del Reglamento (CEE) número $1048 / 71$, asi como los articulos 87, 89, 98 y 120 del Reglamento (CEE) número $574 / 72$, serán aplicables por analogia a dichos trabajadores.

Sin embargo, no podrán contravenirse las disposiciones de la legislación de un Estado miembro que establezcan que las prestaciones familiares deberán abonarse por los miembros de la familia independientemente del país de residencia de los mismos.

2. No obstante el artículo 6 del Reglamento (CEE) número $1408 / 71$, las disposiciones siguientes de los convenios de seguridad social continuarán siendo aplicables a los trabajadores españoles durante el período contemplado en el apartado 1:

a) España-Bélgica

- Apartados 2 y 3 del artículo 20 del convenio general de 28 de noviembre de 1956.

- Artículos 59, 60 y 61 del Acuerdo administrativo de 30 de julio de 1969.

b) España-Alemania

- Los puntos 1 a 4 del apartado 1 del artículo 40 del Convenio de 4 de diciembre de 1973, modificado por el artículo 2 del acuerdo modificativo de 17 de diciembre de 1975.

c) España-Italia

- Articulos 25 y 26 del Convenio de 30 de octubre de 1979.

- Artículos 31 y 32 del Acuerdo administrativo de 30 de octubre de 1979.

d) España-Luxemburgo

- Artículo 29 del Convenio de 8 de mayo de 1969 , modificado por el artículo 3 del segundo Acuerdo complementario de 29 de marzo de 1978 .

- Artículo 30 del Acuerdo administrativo de 25 de mayo de 1971.

e) España-Países Bajos

- Apartados 2 y 5 del artículo 37 del Convenio de 5 de febrero de 1974.

- Artículos 46 y 47 del Acuerdo administrativo de 5 de febrero de 1974 .

f) España-Portugal

- Artículos 23 y 24 del Convenio general de 11 de junio de 1969.

- Artículos 45 y 46 del Acuerdo administrativo de 22 de mayo de 1970 .

g) España-Reino Unido

- Artículo 22 del Convenio de 13 de septiembre de 1974.

- Artículo 17 del Acuerdo de 30 de octubre de 1974. 
Sección II.-Movimientos de capitales

Art. 61. 1. El Reino de España podrá diferir, en las condiciones y plazos señalados en los artículos 62 a 66, la liberalización de los movimientos de capitales enumerados en las listas A y B de la Primera Directiva del Consejo de 11 de mayo de 1960 para la ejecuición del artículo 67 del Tratado CEE y de la segunda Directiva del Consejo de 18 de diciembre de 1962 por la que se completa y modifica la Primera Directiva para la ejecución del artículo $67 \mathrm{del}$ Tratado CEE.

2. A su debido tiempo, se celebrarán consultas apropiadas entre las autoridades españolas y la Comisión sobre las modalidades de aplicación de las medidas de liberalización o de flexibilidad, cuya aplicación podrá diferirse en virtud de las disposiciones siguientes.

Art. 62. El Reino de España podrá diferir:

a) hasta el 31 de diciembre de 1988, la liberalización de las inversiones directas efectuadas por residentes en España en las empresas de los demás Estados miembros que tengan por objeto la adquisición y la propiedad de títulos valores,

b) hasta el 31 de diciembre de 1990, la liberalización de las inversiones directas efectuadas por residentes en España en las empresas de los demás Estados miembros que tengan por objeto la adquisición, la posesión o la explotación de bienes inmuebles.

Art. 63. El Reino de España podrá diferir hasta el 31 de diciembre de 1990 la liberalización de las inversiones inmobiliarias en los demás Estados miembros efectuadas por residentes en España siempre que dichas inversiones no estén relacionadas con la emigración en el marco de la libre circulación de los trabajadores o del derecho de establecimiento.

Art. 64. El Reino de España podrá diferir hasta el 31 de diciembre de 1988 la liberalización de las adquisiciones en los demás Estados miembros por residentes en España de títulos extranjeros negociados en bolsa.

No obstante, la liberalización de las adquisiciones:

- de dichos títulos por las compañias de seguros, los bancos de depósitos y los bancos industriales hasta un máximo del 10 por 100 del incremento de sus recursos propios;

- de dichos títulos por los fondos y sociedades de inversión mobiliaria en las condiciones establecidas por las. disposiciones nacionales que regulan dichos fondos y sociedades;

- de valores de renta fija, emitidos por las Comunidades Europeas y el Banco Europeo de Inversiones,

se efectuará desde el momento de la adhesión.

Art. 65. El Reino de España llevará a cabo, si las circunstancias lo permiten, la liberalización de los movimientos de capitales prevista en los artículos 62, 63 y 64 antes de la expiración de los plazos contemplados en dichos artículos.

Art. 66. Para la aplicación de las disposicions de la presente Sección, la Comisión podrá consultar al Comité Monetario y presentar al Consejo cuantas propuestas fueren apropiadas.

\section{CAPITULO III}

\section{Aoricultura}

\section{Sección I.-Disposiciones generales}

Art. 67. 1. El presente Capitulo se refiere a los productos agrícolas, a excepción de los productos comprendidos en el Reglamento (CEE) número $3796 / 81$ por el que se establece la organización común de mercados en el sector de los productos de la pesca.

2. Salvo disposición en contrario del presente Capítulo, las normas previstas en la presente Acta serán aplicables a los productos agricolas contemplados en el apartado 1 .

3. Sin perjuicio de disposiciones particulares del presente Capítulo que 
prevean fechas diferentes o plazos más breves, la aplicación de las medidas transitorias a los productos agricolas contemplados en el apartado 1 concluirá al finalizar el año 1995.

\section{Subsección 1.-Aproximación $y$ compensación de precios}

Art. 68. Hasta la primera de las aproximaciones de precios contempladas en el artículo 70 , los precios que deberán aplicarse en España se fijarán, según las normas previstas en la organización común de mercados en el sector de que se trate, a un nivel correspondiente al de los precios fijados en España, durante un periodo representativo a determinar para cada producto, con arreglo al régimen nacional anterior.

Si para un producto determinado no existiere definición del precio español, el precio que se aplicará en España será fijado en función de los precios efectivamente registrados en los mercados españoles durante un periodo representativo a determinar.

Sin embargo, a falta de datos sobre los precios respecto de determinados productos en el mercado español, el precio que se aplicará en España se calculará tomando como base los precios existentes en la Comunidad en su composición actual de los productos o grupos de productos similares, o con los cuales estén en competencia.

Art. 69. 1. Si, en la fecha de la adhesión, se comprobare que la diferencia entre el nivel del precio de un determinado producto en España y el del precio común es minima, el precio común podrá aplicarse en España al producto de que se trate.

2. La diferencia contemplada en el apartado 1 se considerará minima cuando sea menor o igual al 3 por 100 del precio común.

Art. 70. 1. Si la aplicación de las disposiciones del artículo 68 condujere en España a un nivel de precios diferentes del de los precios comunes, los precios a los que hace referencia el presente articulo en la sección II, serán, sin perjuicio de las disposiciones del apartado 4, aproximados a los precios comunes cada año al principio de la campaña de comercialización, de conformidad con las disposiciones de los apartados 2 y 3 .

2. Cuando el precio de un producto, en España, sea inferior al precio común, la aproximación se realizará en siete etapas, incrementándose el precio, en España, en el momento de las seis primeras aproximaciones, sucesivamente en un séptimo, un sexto, un quirito, un cuarto, un tercio y en la mitad de la diferencia entre el nivel del precio de este Estado miembro y el nivel de los precios comunes aplicables antes de cada aproximación; el precio resultante de este cálculo será aumentado o disminuido en proporción al aumento o a la disminución eventual del precio común para la campaña venidera; el precio común se aplicará en España en el momento de la séptima aproximación.

3. a) Cuando el precio de un producto en España sea superior al precio común, el precio en este Estado miembro se mantendrá al nivel que resulte de la aplicación del artículo 68 , siendo la aproximación resultado de la evolución de los precios comunes durante los siete años siguientes a la adhesión.

Sin embargo, el precio en España se adaptará en la medida necesaria para evitar una ampliación de la diferencia entre este precio y el precio común.

Además, si los precios españoles, expresados en ECUs, fijados con arreglo al régimen nacional anterior para la campaña 1985/1986, dieren lugar a un aumento de la diferencia existente para la campaña 1984/1985 entre los precios españoles' y los precios comunes, los precios en España que resulten de la aplicación de los dos párrafos precedentes, serán disminuidos en una cuantía a determinar, equivalente a una parte de dicho aumento; de tal forma que éste sea totalmente absorbido en el transcurso de las siete primeras campañas de comercialización siguientes a la adhesión. 
Sin perjuicio de lo dispuesto en la letra $b$ ), el precio común se aplicará en el momento de la séptima aproximación.

b) Cuando el precio de un producto en España sea sensiblemente más alto que el precio común, el Consejo procederá, al final del cuarto año siguiente a la adhesión, a un análisis de la evolución de la aproximación de precios, basándose en un dictamen de la Comisión, acompañado, en su caso, de propuestas adecuadas.

El Consejo, por mayoría cualificada, à propuesta de la Comisión y previa consulta al Parlamento Europeo, podrá, en particular, prolongar el período de aproximación de precios, dentro del límite de la duración máxima del período de aplicación de las medidas transitorias, así como decidir otros métodos de aproximación acelerada de precios.

4. Con objeto de asegurar un funcionamiento equilibrado del proceso de integración, podrá decidirse que, no obstante lo dispuesto en el apartado 2, el precio de uno o de varios productos en España difiera, durante una campaña, de los precios que resulten de la aplicación de este apartado.

Esta diferencia no podrá exceder del 10 por 100 de la cuantía del movimiento de precios que deba efectuarse.

En tal caso, el nivel de precios para la campaña siguiente será el que habria resultado de la aplicación del apartado 2 , de no haberse decidido tal diferencia. Sin embargo, podrá decidirse, para esa campaña, otra diferencia con respecto a dicho nivel, en las condiciones previstas en los párrafos primero y segundo.

La excepción prevista en el párrafo primero no se aplicará a la últimá aproximación contemplada en el apartado 2.

Art. 71. Si, en la fecha de la adhesión o en el transcurso del periodo de aplicación de las medidas transitorias, el precio en el mercado mundial de un determinado producto superase el precio común, podrá aplicarse, en España, el precio común al producto de que se trate, salvo que el precio aplicado en España sea superior al precio común.
Art. 72. Las diferencias en los niveles de precios respecto de los cuales, en - la seccín II, se hace referencia al presente artículo serán compensadas del modo siguiente:-

1. Para los productos respecto de los cuales se hayan fijado precios de conformidad con lo dispuesto en los articulos 68 y 70 , los montantes compensatorios aplicables en los intercambios entre la Comunidad en su composición actual y España, y entre España y terceros países, serán iguales a la diferencia entre los precios fijados para España y los precios comunes.

Sin embargo, el montante compensatorio fijado con arreglo a las normas antes mencionadas será, en su caso, corregido a fin de tener en cuenta igualmente la incidencia de las ayudas nacionales que el Reino de España está autorizado a mantener en virtud del articulo 80 .

2. No se fijará ningún montante compensatorio cuando la aplicación del apartado 1 conduzca a un montante minimo.

3. a) En los intercambios entre España y la Comunidad en su composición actual, los montantes compensatorios serán percibidos por el Estado importador o concedidos por el Estado exportador.

b) En los intercambios entre España y los terceros países, las exacciones reguladoras u otros gravámanes a la importación aplicados en el marco de la política agrícola común, así como, salvo excepciones expresamente establecidas, las restituciones a la exportación, serán, según los casos, reducidos o aumentados en la cuantía de los montantes compensatorios aplicables en los intercambios con la Comunidad en su composición actual.

Sin embargo, los derechos de aduana no podrán ser reducidos en la cuantía del montante compensatorio.

4. Para los productos respecto de los cuales el derecho del arancel aduanero común esté consolidado en el marco del Acuerdo General sobre Aranceles Adua- 
neros y Comercio se tendrá en cuenta la consolidación.

5. El montante compensatorio percibido o concedido por un Estado miembro de conformidad con el apartado 1 no podrá ser superior al montante total percibido por dicho Estado miembro sobre las importaciones procedentes de los terceros países que se beneficien de la cláusula de nación más favorecida. El Consejo, por mayoria cualificada y a propuesta de la Comisión, podrá apartarse de esta norma, en particular para evitar desviaciones del tráfico comercial y distorsiones en la competencia.

6. El Consejo, por mayoria cualificada y a propuesta de la Comisión, podrá apartarse, en la medida necesaria para el buen funcionamiento de la política agrícola común, de las dișposiciones del párrafo primero del artículo 53 respecto de los productos a los que se apliquen montantes compensatorios.

Art. 73. Cuando .el precio del mercado mundial de un producto sea superior al precio utilizado para el cálculo del gravamen a la importación establecido en el marco de la política agricola común, menos el montante compensatorio deducido del gravamen a la importación en aplieación del artículo 72, o cuando la restitución a las exportaciones a los terceros países sea inferior al montante compensatorio, 0 de no ser aplicable restitución alguna, podrán adoptarse las medidas apropiadas a fin de asegurar el buen funcionamiento de la organización común de mercados.

Art. 74. 1. Los montantes compensatorios concedidos serán financiados por la Comunidad con cargo al Fondo Europeo de Orientación y de Garantía Agrícola, Sección Garantía.

2. Los gastos que deberá efectuar el Reino de España en materia de intervención en su mercado interior $y$ de concesión de restituciones o de subvenciones a las exportaciones a los terceros paises y a los demás Estados miembros seguirán siendo nacionales hasta el 31 de diciembre de 1989 en lo que se refiere a los productos comprendidos en el Reglamento (CEE) número 1035/1972, por el que se establece la organización común de mercados en el sector de las frutas y hortalizas.

Sin embargo, la Comunidad participará en la financiación de las operaciones de intervención realizadas por el Reino de España durante la fase de verificación de convergencia aplicable a dichos productos en las condiciones previstas en el artículo 133.

A partir de la segunda fase los gastos en materia de intervención en el mercado interior español y de concesión de restituciones a la exportación hacia terceros países serán financiados por la Comunidad con cargo al Fondo Europeo de Orientación y de Garantía Agricola, Sección Garantia.

\section{Subsección 2.-Libre circulación y unión aduanera}

Art. 75. Las siguientes disposiciones se aplicarán a los productos procedentes de los terceros países cuya importación en la Comunidad en su composición actual esté sujeta a la aplicación de derechos de aduana:

1. Sin perjuicio de lo dispuesto en los apartados 4 y 5 los derechos de aduana de importación serán suprimidos progresivamente entre la Comunidad en su composición actual y España según el ritmo siguiente:

- el 1 de marzo de 1986, cada derecho quedará reducido al 87,5 por 100 del derecho de base,

- el 1 de enero de 1987, cada derecho quèdará reducido al 75 por 100 del derecho de base,

- el 1 de enero de 1988 , cada derecho quedará reducido al 62,5 por 100 del derecho de base,

- el 1 de enero de 1989, cada derecho quedará reducido al 50 por $100 \mathrm{del}$ derecho de base,

- el 1 de enero de 1990, cada derecho quedará reducido al 37,5 por $100 \mathrm{del}$ derecho de base, 
- el 1 de enero de 1991, cada derecho quedará reducido al 25 por 100 del derecho de base,

- el 1 de enero de 1992, cada derecho quedará reducido al 12,5 por 100 del derecho de base,

- el 1 de enero de 1993, quedarán suprimidos todos los derechos.

Sin embargo:

a) para los productos comprendidos en el Reglamento (CEE) número $1035 / 1972$, el desarme arancelario se efectuará durante un periodo transitorio de diez años del modo siguiente:

- respecto de los productos a los que se fije un precio de referencia, los derechos serán suprimidos progresivamente a lo largo de once etapas anuales según el ritmo siguiente:

- el 1 marzo de 1986, un 10 por 100 ,

- el 1 enero de 1987, un 10 por 100 ,

- el 1 enero de 1988, un 10 por 100 ,

- el 1 enero de 1989, un 10 por 100,

- el 1 enero de 1990, un 25 por 100,

- el 1 enero de 1991, un 15 por 100,

- el 1 enero de 1992, un 4 por 100,

- el 1 enero de 1993, un 4 por 100,

- el 1 enero de 1994, un 4 por 100,

- el 1 enero de 1995, un 4 por 100 ,

- el 1 enero de 1996, un 4 por 100;

- respecto de los demás productos, los derechos de aduana serán suprimidos según el ritmo siguiente:

- el 1 de marzo de 1986, cada derecho quedará reducido al 90,9 por 100 del derecho de base,

- el 1 de enero de 1987, cada derecho quedará reducido al 81,8 por 1.00 del derecho de base,

- el 1 de enero de 1988, cada derecho quedará reducido al 72,7 por 100 del derecho de base,

- el 1 de enero de 1989, cada derecho quedará reducido al 63,6 por 100 del derecho de base,

- el 1 de enero de 1990, cada derecho quedará reducido al 54,5 por 100 del derecho de base,

- el 1 de enero de 1991, cada derecho quedará reducido al 45,4 por 100 del derecho de base,

- el 1 de enero de 1992, cada derecho quedará reducido al 36,3 por 100 del derecho de base,

- el 1 de enero de 1993, cada derecho quedará reducido al 27,2 por 100 del derecho de base,

- el 1 de enero de 1994, cada derecho quedará reducido al 18,1 por 100 del derecho de base,

- el 1 de enero de 1995, cada derecho quedará reducido al 9 por 100 del derecho de base,

- el 1 de enero de 1996, quedarán suprimidos todos los derechos;

b) para los productos comprendidos en el Reglamento (CEE) número $805 / 1968$, por el que se establece la organización común de mercados en el sector de la carne de bovino, los derechos de aduana serán -suprimidos progresivamente en ocho etapas en porcentajes del. 12,5 por 100 al principio de cada una de las ocho campañas de comercialización siguientes a la adhesión;

c)' para las semillas y frutos oleaginosos y sus productos derivados comprendidos en la partida $12.01 \mathrm{~B}$ del arancel aduanero común asi como para los productos comprendidos en las partidas 12.02 y 23.04 B del arancel aduanero común, los derechos de aduana de importación serán suprimidos progresivamente entre la Comunidad en su composición actual y España según el ritmo siguiente:

- el 1 de marzo de 1986, cada derecho quedará reducido al 90,9 por 100 del derecho de base,

- el 1 de enero de 1987, cada derecho quedará reducido al 81,8 por 100 del derecho de base,

- el 1 de enero de 1988, cada derecho quedará reducido al 72,7 por 100 del derecho de base,

- el 1 de enero de 1989, cada derecho quedará reducido al 63,6 por 100 del derecho de base,

- el 1 de enero de 1990, cada derecho quedará reducido al 54,5 por 100 del derecho de base, 
- el 1 de enero de 1991, cada derecho quedará reducido al 45,4 por 100 del derecho de base,

- el 1 de enero de 1992, cada derecho quedará reducido al 36,3 por 100 del derecho de base,

- el 1 de enero de 1993, cada derecho quedará reducido al 27,2 por 100 del derecho de base,

- el 1 de enero de 1994, cada derecho quedará reducido al 18,1 por 100 del derecho de base,

- el 1 de enero de 1995, cada derecho quedará reducido al 9 ,por 100 del derecho de base,

- el 1 de enero de 1996, quedarán suprimidos todos los derechos;

d) para los productos contemplados en la letra b) del apartado 2 del articulo 1 del Reglamento número 136/1966/CEE, con excepción de los comprendidos en las partidas 12.02 y 23.04 B del arancel aduanero común, la Comunidad eh su composición actual y el Reino de España aplicarán, sin modificación alguna, sus derechos de base respectivos y exacciones de efecto equivalente durante el periodo de aplicación en España de determinados mecanismos de control contemplados en el artículo 94 .

Al término de dicho periodo, el Reino de España suprimirá integramente las exacciones de efecto equivalente a derechos de aduana y los derechos de aduana serán suprimidos progresivamente según el ritmo siguiente:

- el 1 de marzo de 1991, cada derecho quedará reducido al 83,3 por 100 del derecho de base,

- el 1 de enero de 1992, cada derecho quedará reducido al 66,6 por 100 del derecho de base,

- el 1 de enero de 1993, cada derecho quedará reducido al 49,9 por 100 del derecho de base,

- el 1 de enero de 1994, cada derecho quedará reducido al 33,2 por 100 del derecho de base,

- el 1 de enero de 1995, cada derecho quedará reducido al 16,5 por $100 \mathrm{del}$ derecho de base.
- el 1 de enero de 1996, quedarán $J$ suprimidos todos. los dẹrechos.

2. Sin perjuicio de lo dispuesto en los apartados 4 y 5 , a los efectos de la implantación por el Reino de España del arancel aduanero común, se aplicarán las disposiciones siguientes:

a) Para los productos siguientes:

- los productos comprendidos en el Reglamento (CEE) número 805/1968, - los productos comprendidos en el Reglamento (CEE) número $1035 / 1972$, a los que se fije un precio de referencia para toda la campaña de comercialización o parte de la misma,

- los productos comprendidos en el Reglamento (CEE) número 337/1979 por el que se establece la organización común del mercado vitivinícola, a los que se fije un precio de referencia,

el Reino de España aplicará íntegramente, desde el 1 de marzo de 1986, los derechos del arancel aduanero común;

b) a los efectos de la implantación progresiva del arancel aduanero común, el Reino de España modificará su arancel aplicable a los terceros países, para las semillas y frutos oleaginosos comprendidos en la partida $12.01 \mathrm{~B}$ del arancel aduanero común así como para todos los productos comprendidos en las partidas 12.02 y $23.04 \mathrm{~B}$ del arancel aduanero común, de la siguiente manera:

aa) en lo que se refiere a las partidas arancelarias cuyos derechos de base no difieren en más de un 15 por 100 por encima o por debajo de los derechos del arancel aduanero común, se aplicarán estos últimos derechos;

bb) en los demás casos, el Reino de España aplicará un derecho que reduzca la diferencia entre el derecho de base y el derecho del arancel aduanero común según el ritmo siguiente:

- el 1 de marzo de 1986, la diferencia quedará reducida al 90,9 por 100 de la diferencia inicial,

- el 1 de enero de 1987 , la diferencia 
d. quedará reducida al 81,8 por 100 de la diferencia inicial,

- el 1 de enero de 1988, la diferencia quedará reducida al 72,7 por 100 de lą diferencia inicial,

- el 1 de enero de 1989, la diferencia quedará reducida al 63,6 por 100 de la diferencia inicial,

- el 1 de enero de 1990, la diferencia quedará reducida al 54,5 por 100 de la diferencia inicial,

- el 1 de enero de 1991, la diferencia quedará reducida al 45,4 por 100 de la diferencia inicial,

- el 1 de enero de 1992, la diferencia quedará reducida al 36,3 por 100 de la diferencia inicial,

- el 1 de enero de 1993, la diferencia quedará reducida al 27,2 por 100 de la diferencia inicial,

- el 1 de enero de 1994, la diferencia quedará reducida al 18,1 por 100 de la diferencia inicial,

- el 1 de enero de 1995, la diferencia quedará reducida al 9 por 100 de la diferencia inicial.

El Reino de España aplicará integramente el arancel aduanero común a partir del 1 de enero de 1996;

c) para los productos contemplados en la letra b) del apartado 2 del artículo 1 del Reglamento número 136/66/CEE con excepción de los comprendidos en las partidas 12.02 y $23.04 \mathrm{~B}$ del arancel aduanero común, el Reino de España aplicará, sin modificación alguna, sus derechos de base y exacciones de efecto equivalente durante el periodo de aplicación en España de determinados mecanismos de control contemplados en el artículo 94 .

Al término de dicho periodo, el Reino de España suprimirá integramente las exacciones de efecto equivalente a derechos de aduana y modificará su arancel aplicable a los terceros paises de la forma siguiente:

aa) respecto de las partidas arancelarias cuyos derechos de base no difieren en más de un 15 por 100 de los derechos del arancel aduanero.común, se aplicarán estos últimos derechos; bb) en los demás casos, el Reino dè España reducirá la diferencia entre el derecho de base y el derecho del arancel aduanero común según el ritmo siguiente:

- el ll de enero de 1991 la diferencia quedará reducida al 83,3 por 100 de la diferencia inicial;

- el 1 de enero de 1992 la diferencia quedará reducida al 66,6 por 100 de la diferencia inicial;

- el 1 de enero de 1993 la diferencia quedará reducida al 49,9 por 100 de la diferencia inicial;

- el 1 de enero de 1994 la diferencia quedará reducida al 33,2 por 100 de la diferencia inicial;

- el 1 de enero de 1995 la diferencia quedará reducida al 16 por 100 de la diferencia inicial.

El Reino de España aplicará íntegramente el arancel aduanero común a partir del 1 de enero de 1996;

d) para los demás productos:

(aa) el Reino de España aplciará el arancel aduanero común integramente, desde el 1 de marzo de 1986, cuando sus derechos de base sean menores o iguales que los del arancel aduanero común, a excepción:

- de la miel natural comprendida en la partida 04.06 del arancel aduanero común y del tabaco en rama o sin elaborar y desperdicios de tabaco comprendidos en la partida 24.01 del arancel aduanero común, respecto de los cuales el Reino de España reducirá la diferencia entre el derecho de base y el derecho del arancel aduanero común en ocho movimientos de un 12,5 por 100 cada uno, realizándose el primero de ellos el 1 de marzo de 1986 y los restantes el 1 de enero de cada año desde 1987 hasta 1993 , ambos inclusive;

- del cacao en grano y partido, crudo o tostado, de la partida 18.01 del arancel aduanero común y del café sin tostar y sin descafeinar de la partida 09.01 A I a) del arancel aduanero 
común para los que el Reino de España reducirá la difẹrencia entre el derecho de base y el derecho del arancel aduanero común según el ritmo siguiente:

- el 1 de marzo de 1986 la diferencia quedará reducida al 83,3 por 100 de la diferencia inicial;

- el 1 dé enero de 1987 la diferencia quedará reducida al 66,6 por 100 de la diferencia inicial;

- el 1 de enero de 1988 la diferencia quedará reducida al 49,9 por 100 de la diferencia inicial;

- el 1 de enero de 1989 la diferencia quedará reducida al 33,2 por 100 de la diferencia inicial;

- el 1 de enero de 1990 la diferencia quedará reducida al 16,5 por 100 de la diferencia inicial.

El Reino de España aplicará integramente el arancel aduanero común a partir del 1 de enero de 1991.

bb) cuando los derechos de base españoles sean superiores a los derechos del arancel aduanero común, el Reino de España modificará su arancel aplicable a los terceros paises de la siguiente forma:

i) respecto de las partidas arancelarias cuyos derechos de base no difieran en más de un 15 por 100 de los derechos del arancel aduanero común, se aplicarán estos últimos derechos;

ii) en los demás casos, el Reino de España aplicará un derecho que reduzca la diferencia entre los derechos de base y los derechos del arancel aduanero común a lo largo de siete etapas iguales de un 12,5 por 100 en las siguientes fechas:

- el 1 de marzo de 1986;

- el 1 de enero de 1987;

- el 1 de enero de 1988;

- el 1 de enero de 1989;

- el 1 de enero de 1990;

- el 1 de enero de 1991 ;

- el 1 de enero de 1992.

El Reino de España aplicará íntegramente el arancel aduanero común a partir del 1 de enero de 1993.
3. Con arreglo a los apartados 1 y 2 , el derecho de base será el definido en el artículo 30 .

Sin embargo:

- respecto de los productos contemplados en el Anexo VIII, el derecho de base será el que figura frente a cada producto de dicho Anexo.

- respecto de las semillas y frutos oleaginosos de la partida $12.01 \mathrm{~B}$ del arancel aduanero común asi como para los productos de las partidas 12.02 y $23.04 \mathrm{~B}$ del arancel aduanero común, sujetos en el régimen nacional anterior a la percepción en el momento de la importación en España de derechos llamados «reguladores» 0 «compensatorios variables», el derecho de base quedará fijado a un nivel pendiente de determinación, en las condiciones previstas en el artículo 91, representativo de la campaña 1984/1985.

4. Para los productos sometidos a la organización común de mercados podrá decidirse, con arreglo al procedimiento previsto en el artículo 38 del Reglamento número $136 / 66 / C E E$ o, según los casos, en los correspondientes artículos de los demás reglamentos por los que se establecen las organizaciones comunes de mercados agricolas, que:

a) España, a instancia propia, procederá:

- a la supresión de los derechos de aduana contemplados en el apartado 1 o a la aproximación de los derechos de aduana aplicables a los productos que no sean los contemplados en el punto 2 a), a un ritmo más rápido que el previsto en estos apartados;

- a la suspensión total o parcial de los derechos de aduana aplicables a los productos importados procedentes de los Estados miembros actuales;

- a la suspensión total o parcial de los derechos de aduana aplicables a los productos importados procedentes de los terceros paises en lo que respecta a los productos distintos de los contemplados en el punto 2 a); 
b) la Comunidad en su composición actual procederá:

- a la supresión de los derechos de aduana contemplados en el punto 1 a un ritmo más rápido que el allí previsto;

- a la suspensión total o parcial de los derechos de aduana contemplados en el punto 1, aplicables a los productos importados procedentes de España.

Respecto de los productos que no estén sometidos a la organización común de mercados:

a) no será precisa decisión alguna para que el Reino de España proceda a la aplicación de las medidas contempladas en los guiones primero y segundo de la letra a) del párrafo primero; el Reino de España notificará a los demás Estados miembros y a la Comisión las medidas adoptadas;

b) la Comisión podrá suspender total o parcialmente los derechos de aduana aplicables a los productos importados procedentes de España.

Los derechos de aduana resultantes de una aproximación acelerada o suspendidos no podrán ser menores que los aplicados a la importación de los mismos productos procedentes de los demás Estados miembros.

5. En caso de dificultades particulares en el mercado de los productos. comprendidos en las partidas 15.17 B II y $23.04 \mathrm{~B}$ del arancel aduanero común, el Reino de España podrá ser autorizado con arreglo al procedimiento previsto en el artículo 38 del Reglamento número 136/66/CEE, para:

a) diferir la reducción que deba efectuarse en virtud del punto 1 c) de los derechos de importación de la Comunidad en su composición actual;

b) diferir la reducción que deba efectuarse en virtud del punto 2 b) de la diferencia existente entre sus derechos de base y el derecho del arancel aduanero común;

c) aumentar, durante el plazo estrictamente necesario para eliminar las difi- cultades encontradas, los derechos de importación antes mencionados en los puntos $a$ ) y $b$ ).

Art. 76. i. Con respecto a los productos sometidos en el momento de la adhesión, a la organización común de mercados, el régimen aplicable en la Comunidad en su composición actual en materia de derechos de aduana y exacciones de efecto equivalente, y de restricciones cuantitativas y medidas de efecto equivalente en los intercambios entre España y los demás Estados miembros y entre España y los terceros paises, se aplicará en España desde el 1 de marzo de 1986, salvo lo dispuesto en contrario en el presente capitulo.

2. Para los productos no sometidos, en el momento de la adhesión, a la organización común de mercados, las disposiciones del Título II de la Cuarta Parte relativas a la eliminación de las exacciones de efecto equivalente a derechos de aduana, $y$ a la supresión progresiva de las restricciones cuantitativas y medidas de efecto equivalente, no se aplicarán a dichas exaccionẹs restrictivas y medidas cuando éstas sean parte integrante de una organización nacional de mercado en España o en otro Estado miembro en la fecha de la adhesión.

Tal disposición sólo será aplicable hasta el establecimiento de la organización común de mercados para dichos productos y, a más tardar, hasta el 31 de diciembre de 1995, y en la medida estrictamente necesaria para asegurar el mantenimiento de la organización nacional.

3. El Reino de España aplicará, desde el 1 de marzo de 1986, la nomenclatura del arancel aduanero común.

Siempre que no surjan dificultades para la aplicación de la normativa comunitaria, y en particular para el funcionamiento de la organización común de mercados y de los mecanismos transitorios previstos en el presente capítulo, el Consejo, por mayoría cualificada, y a propuesta de la Comisión, podrá autorizar al Reino de España para que incluya en esta nomenclatura las 
subdivisiones nacionales existentes que fueren indispensables para que la aproximación progresiva al arancel aduanero común o la supresión de los derechos dentro de la Comunidad se efectúe en las condiciones previstas en la presente Acta.

Art. 77. Sin perjuicio de lo dispuesto en el artículo 94, el Reino de España podrá mantener, con arreglo a unas modalidades pendientes de determinación, restricciones cuantitativas a las importaciones procedentes de terceros países:

a) respecto de los siguientes productos, hasta el 31 de diciembre de 1989:

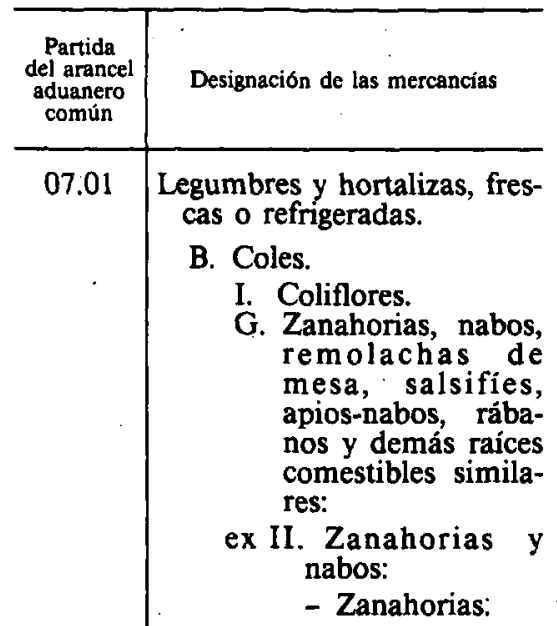

08.02 Agrios, frescos o secos:

A. Naranjas.

B. Mandarinas, incluidas las tangerinas y satsumas; clementinas, wilkings y demás hibridos similares de agrios:

\begin{tabular}{c|c}
\hline $\begin{array}{c}\text { Partida } \\
\text { del arancel } \\
\text { aduanero } \\
\text { común }\end{array}$ & Designación de las mercancias \\
\hline 08.02 & \multicolumn{1}{c}{ ex II. Las demás: } \\
$-\begin{array}{c}\text { Mandarinas, } \\
\text { incluidas las } \\
\text { tangerinas y sat- } \\
\text { sumas. }\end{array}$ \\
08.04 & $\begin{array}{l}\text { C. Limones. } \\
\text { Avas y pasas: } \\
\text { A. Uvas: } \\
\text { I. de mesa. } \\
\text { Manzanas, peras y membri- } \\
\text { Ilos frescos: } \\
\text { A. Manzanas. } \\
\text { B. Peras. } \\
\text { Frutas de hueso, frescas: } \\
\text { A. Albaricoques. } \\
\text { ex B. Melocotones, inclui- } \\
\text { dos los griñones y nec- } \\
\text { tarinas: } \\
\text { - Melocotones. }\end{array}$ \\
\hline
\end{tabular}

b) para los productos contemplados en el artículo 1 del Reglamento (CEE) número $2759 / 75$ así como para los productos siguientes hasta el 31 de diciembre de 1995:

\begin{tabular}{|c|c|}
\hline $\begin{array}{l}\text { Partida } \\
\text { del arancel } \\
\text { aduanero } \\
\text { comun }\end{array}$ & Designación de las mercancias \\
\hline 02.04 & $\begin{array}{l}\text { Las demás carnes y despojos } \\
\text { comestibles; frescos, refri- } \\
\text { gerados o congelados: }\end{array}$ \\
\hline & $\begin{array}{l}\text { ex A. de palomas domésti- } \\
\text { cas y de conejos } \\
\text { domésticos: } \\
\text { - Carnes de conejos } \\
\text { domésticos. }\end{array}$ \\
\hline 11.01 & $\begin{array}{l}\text { Harinas de cereales: } \\
\text { A. de trigo o de morcajo o } \\
\text { tranquillón. }\end{array}$ \\
\hline
\end{tabular}




\begin{tabular}{c|c}
\hline $\begin{array}{c}\text { Partida } \\
\text { del arancel } \\
\text { aduanero } \\
\text { común }\end{array}$ & Designación de las mercancias \\
\hline 11.02 & $\begin{array}{c}\text { Grañones y sémolas; granos } \\
\text { mondados, perlados, parti- } \\
\text { dos, aplastados o en copos, } \\
\text { excepto el arroz de la par- } \\
\text { tida 10.06; gérmenes de } \\
\text { cereales, enteros, aplasta- } \\
\text { dos, en copos o molidos: } \\
\text { A. Grañones y sémolas. } \\
\text { B. Granos mondados } \\
\text { (descascarillados } \\
\text { pelados) incluso corta- } \\
\text { dos o partidos. }\end{array}$ \\
$\begin{array}{c}\text { C. Granos perlados. } \\
\text { D. Granos solamente par- } \\
\text { tidos. }\end{array}$ \\
$\begin{array}{c}\text { ex E. Granos aplastados; } \\
\text { copos: } \\
\text { - Granos aplastados. } \\
\text { G. Gérmenes de cereales, } \\
\text { enteros, aplastados, en } \\
\text { copos o molidos. }\end{array}$ \\
$\begin{array}{c}\text { Almidones y féculas; inulina: } \\
\text { A. Almidones y féculas: } \\
\text { III. Almidón de trigo. } \\
\text { Gluten de trigo, incluso seco. }\end{array}$ \\
\hline 11.08
\end{tabular}

c) para los productos sometidos al mecanismo complementario aplicable a la importación en España procedentes de la Comunidad en su composición actual, contemplado en el artículo .81 , que no sean los comprendidos en el Reglamento (CEE) n. ${ }^{\circ} 1035 / 72$.

Art: 78. 1. El elemento destinado a asegurar la protección de la industria de transformación utilizado para el cálculo del gravamen a la importación de productos procedentes de los terceros países sometidos a la organización común de mercados en los sectores de los cereales y del arroz gravará las importaciones en la Comunidad en su composición actual procedentes de España.

2. Respectó a las importaciones en España, la cuantía de este elemento se determinará separando de la protección aplicada el 1 de enero de 1985, el elemento o los elementos que estaban destinados a asegurar la protección de la industria de transformación; no obstante, esa cuantia no podrá rebasar el nivel del elemento de protección comunitaria fijada para el mismo producto. Cuando dificultades particulares de cuantificación no permitan la determinación del elemento de protección aplicable en España, este Estado miembro aplicará inmediatamente el elemento de protección comunitario.

Estos elementos gravarán las importaciones procedentes de los otros Estados miembros; sustituirán, en lo que' respecta a los gravámenes sobre las importaciones procedentes de' los terceros paises, al elemento de protección comunitario.

3. Las disposiciones del artículo 75 se aplicarán al elemento contemplado en los apartados 1 y 2 , que será considerado como elemento de base. Sin embargo, las reducciones o aproximaciones referidas se efectuarán en ocho etapas en porcentajes del 12,5 por 100 al principio de cada una de las ocho campañas de comercialización siguientes a la adhesión fijadas para el producto básico de que se trate.

\section{Subsección 3.-Ayuidas}

Art. 79. 1. Las disposiciones del presente artículo se aplicarán a las ayudas, primas u otras cuantías análogas establecidas al amparo de la política agrícola común, respecto de las cuales, en la Sección 2, se hace referencia al presente articulo.

2. Con objeto de introducir las ayudas comunitarias en España, se aplicarán las disposiciones siguientes:

a) el nivel de ayuda comunitaria que deba concederse para un producto determinado en España, desde el 1 de marzo de 1986, será igual a una cuantía definida de acuerdo con las ayudas concedidas por España, durante un periodo representativo a determinar, con arreglo al régimen nacional anterior. 
Sin embargo, esta cuantía no podrá exceder de la cuantía de la ayuda concedida el día de la adhesión en la Comunidad en su composición actual.

$\mathrm{Si}$ con arreglo al régimen nacional anterior no se concedia ninguna ayuda análoga, salvo lo dispuesto a continuación, no se concederá ninguna ayuda comunitaria en España el 1 de marzo de 1986;

b) al principio de la primera campaña de comercialización 0 , a falta de ello, del primer periodo de aplicación de la ayuda siguiente a la adhesión:

- o bien se introducirá en España la ayuda comunitaria a un nivel que represente un séptimo de la cuantía de la ayuda comunitaria aplicable a la campaña o período venideros,

- o bien el nivel de la ayuda comunitaria en España será, en caso de que exista una diferencia, aproximada al nivel de la ayuda aplicable en la Comunidad en su composición actual a la campaña o periodo venideros en un séptimo de la diferencia existente entre ambas ayudas;

c) al principio de las campañas o periodos de aplicación siguientes, el nivel de la ayuda comunitaria en España será aproximado al nivel de la ayuda aplicable en la Comunidad en su composición actual para la campaña o periodo venideros, sucesivamente, en un sexto, un quinto, un cuarto, un tercio y en la mitad de la diferencia existente entre ambas ayudas.

d) el nivel de la ayuda comunitaria será integramente aplicado en España al principio de la séptima campaña de comercialización o del período de aplicación de la ayuda siguiente a la adhesión.

Art. 80. 1. Sin perjuicio de las disposiciones del articulo 79, el Reino de España estará autorizado para mantener las ayudas nacionales cuya supresión no dejaria de tener graves consecuencias en el nivel de precios, tanto en la producción como en el consumo. Sin embargo, estas ayudas sólo podrán mantenerse con carácter transitorio y, en principio, decreciente a más tardar hasta la conclusión del periodo de aplicación de las medidas transitorias.

2. El Consejo, en las condiciones previstas en el articulo 91, adoptará las medidas necesarias para la aplicación de las disposiciones del presente artículo. Estas medidas comprenderán, en particular, la lista y la denominación exacta de las ayudas contempladas en el apartado 1 , sus importes, su ritmo de supresión, la eventual escala de reducción, asi como las modalidades necesarias para el buen funcionamiento de la política agricola común; estas modalidades deberán, además, asegurar a los medios de producción, ya sean de origen español $u$ originarios de los demás Estados miembros, una igualdad de acceso al mercado español.

3. En caso necesario, durante el periodo de aplicación de las medidas transitorias, podrán admitirse excepciones a la escala de reducción contemplada en el apartado 2.

\section{Subsección 4.-El mecanismo comple- mentario de los intercambios}

Art. 81. 1. Se crea un mecanismo complementario aplicable a los intercambios entre la Comunidad en su composición actual y España, denominado en lo sucesivo «MCI».

El mecanismo se aplicará desde el 1 de marzo de 1986 hasta el 31 de diciembre de 1995, excepto a los productos contemplados en el guión primero de la letra a) del apartado 2, a los que se les aplicará desde el 1 de enero de 1990 hasta el 31 de diciembre de 1995.

\section{Quedarán sometidos al MCI:}

a) en lo que se refiere a las importaciones en la Comunidad en su composición actual, los productos siguientes:

- productos del sector de frutas y hortalizas comprendidas en el Reglamento (CEE) número 1035/72; 
- productos del sector vitivinícola comprendidos en el Reglamento (CEE) número $337 / 79$;

- patatas tempranas comprendidas en la subpartida 07.01 A II del arancel aduanero común;

b) en lo que se refiere a las importaciones en España, los productos siguientes:

aa) los productos del sector vitivinicola comprendidos en el Reglamento (CEE) número 337/79;

\begin{tabular}{|c|c|}
\hline $\begin{array}{c}\text { Partida } \\
\text { del arancel } \\
\text { aduanero } \\
\text { común }\end{array}$ & Designación de las mercancías \\
\hline bb) 01.02 & $\begin{array}{l}\text { Animales vivos de la especie } \\
\text { bovina, incluso los del } \\
\text { género búfalo: }\end{array}$ \\
\hline
\end{tabular}

A. de las especies domésticas: ex II. los demás:

- excepto los animales para corridas.

02.01 Carnes y despojos comestibles de los animales comprendidos en las partidas $01.01 \mathrm{a}$ 01.04, ambas inclusive, frescos, refrigerados o congelados:

A: Carnes:

II. de bovinos

B. Despojos:

II. los demás:

b) de bovinos

02.06 Carnes y despojos comestibles de cualquier clase (con exclusión de los hígados de ave) salarios o en salmuera, secos o ahumados:

C. Los demás:

I. de la especie bovina

04.01

04.02

\begin{tabular}{|c|c|}
\hline $\begin{array}{l}\text { Partida } \\
\text { del arancel } \\
\text { aduanero } \\
\text { común }\end{array}$ & Designación de las mercancias \\
\hline 04.02 & $\begin{array}{l}\text { A. sin azucarar: } \\
\text { ex II. leche y nata en polvo } \\
\text { o en gránulos: } \\
\text { - destinadas al consumo } \\
\text { humano }\end{array}$ \\
\hline
\end{tabular}

B. con adición de azúcar:

I. Leche y nata, en polvo o en gránulos:

a) Leches especiales llamadas «para lactantes» en recipientes herméticamente cerrados de un contenido de 500 g como máximo, con un contenido en peso de materias grasas superior al 10 por 100 pero sin exceder del 27 por 100:

ex b) las demás:

- destinadas al consumo humano

04.03

Mantequilla

04.04 Quesos y requesón:

A. Emmental, Gruyère, Sbrinz, Bergkäse, Appenzell, Vacherin friburgeois y tête de moine, excepto rallados o en polvo

B. Quesos de Glaris con hierbas (llamados Schabziger), fabricados con leche desnatada y adicionados de hierbas finamente molidas

C. Quesos de pasta azul, excepto rallados o en polvo

D. Quesos fundidos, excepto rallados o en polvo

E. Los demás:

I. los demás, excepto rallados o en polvo, con un contenido en peso de materias grasas inferior o igual al 40 por 100 , y con un contenido en 


\begin{tabular}{|c|c|}
\hline $\begin{array}{l}\text { Partida } \\
\text { del arance } \\
\text { aduanero } \\
\text { común }\end{array}$ & Designación de las mercancias \\
\hline 04.04 & $\begin{array}{l}\text { peso de agua en la mate- } \\
\text { ria no grasa: } \\
\text { ex a) inferior o igual al } \\
47 \text { por } 100 \text { : } \\
\text { - con exclusión del requesón } \\
\text { b) superior al } 47 \text { por } 100 \text { e } \\
\text { inferior o igual al } 72 \text { por } \\
100 \text { : } \\
\text { 1. Cheddar } \\
\text { ex 2. los demás } \\
\text { - con exclusión del requesón } \\
\text { c) superior al } 72 \text { por } 100: \\
\text { ex } 1 \text {. en envases inmediatos } \\
\text { con un contenido neto } \\
\text { inferior o igual a } 500 \text { g: } \\
\text { - con exclusión del requesón } \\
\text { ex } 2 \text {. los demás: } \\
\text { - con exclusión del requesón } \\
\text { II. los demás: }\end{array}$ \\
\hline
\end{tabular}

ex rallado o en polvo

- con exclusión del requesón

cc)

07.01 Legumbres y hortalizas, frescas o refrigeradas:

B. Coles:

\section{Coliflores.}

raices comestibles similares:

ex II.Zanahorias y nabos:

$$
\text { - Zanahorias }
$$

exH. Cebollas, chalotes y ajos:

\section{- Cebollas y ajos}

08.02 agrios, frescos o secos:

A. Naranjas

B. Mandarinas, incluidas las tangerinas y satsumas; clementinas, wilking y demás hibridos similares de agrios:

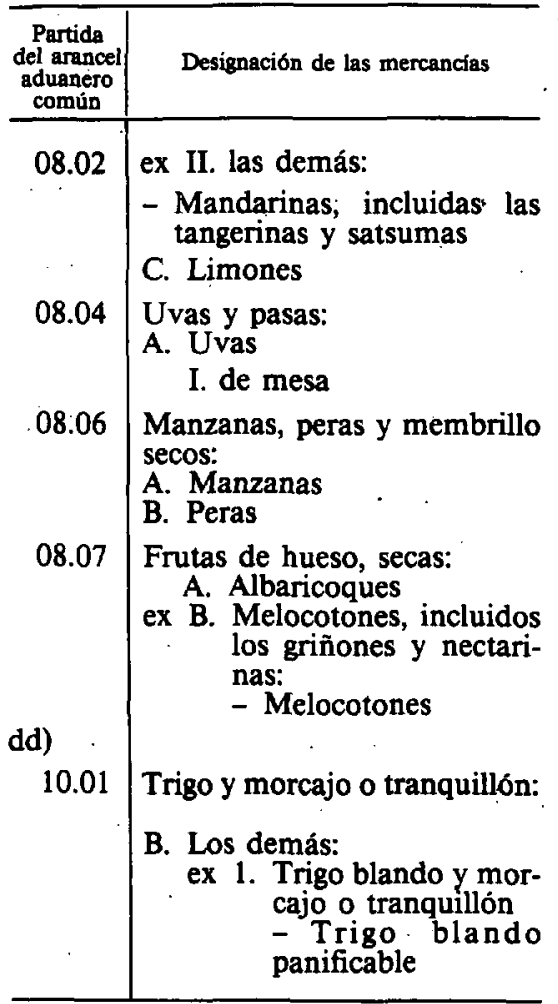

3. Podrá decidirse, con arreglo al procedimiento previsto en el articulo 82 , retirar de la lista de los productos sometidos al MCI:

a) los productos del sector vitivinicola, las patatas tempranas y la leche en polvo o granulada destinados a la alimentación humana, al principio del segundo año siguienté a la adhesión $0 \cdot a l$ principio de cada uno de los años sucesivos;

b) las frutas y hortalizas, a más tardar, nueve meses antes del vencimiento del cuarto año siguiente a la adhesión o al principio de cada uno de los años sucesivos: 
c) los demás productos contemplados en la letra b) del apartado 2, a partir del quinto año siguiente a la adhesión y al principio de cada uno de los años sucesivos.

En lo que se refiere a estos productos, se tendrá en cuenta en particular la situación respecto de las estructuras de producción y comercialización de los productos de que se trate.

4. Podrá decidirse, con arreglo al procedimiento previsto en el articulo 11 del Reglamento (CEE) número $2358 / 1971$ por el que se establece la organización común de mercados en el sector de semillas, someter al $\mathrm{MCI}$ durante el periodo que se extiende del 1 de marzo de 1986 al 31 de diciembre de 1989, las importaciones en España de patata para siembra certificada de calidad inferior comprendidas en la partida $07.01 \mathrm{~A}$ I del arancel aduanero común, siendo competente para ello el Comité de gestión creado por el mencionado Reglamento.

5. En caso de dificultad particular, podrá decidirse, a instancia del Reino de España y de acuerdo con el procedimiento previsto en el artículo 82, completar la lista de los productos sometidos al MCI en el momento de la importación en España en lo que se refiere a los productos comprendidos en el Reglamento (CEE) número 1035/72 no contemplados en la letra b) del apartado 2.

6. La Comisión presentará al Consejo, al principio de cada año, un informe sobre el funcionamiento del $\mathrm{MCI}$ durante el año anterior.

Art. 82. 1. Se crea un Comité ad hoc, compuesto por representantes de los Estados miembros y presidido por un representante de la Comisión.

2. En el Comité ad hoc se aplicará a los votos de los Estados miembros la ponderación prevista en el apartado 2 del artículo 148 del Tratado CEE. El presidente no participará en la votación.

3. Cuando se invoque el procedimiento definido en el presente articulo, el Comité ad hoc será convocado sin demora por su presidente, bien por su propia iniciativa, bien a instancia de un Estado miembro.

4. El representante de la Comisión presentará un proyecto de las medidas que deban adoptarse. El Comité emitirá un dictamen acerca de estas medidas en un plazo que el presidente podrá fijar atendiendo a la urgencia de las cuestiones presentadas a examen. El Comité se pronunciará por mayoría de cincuenta y cuatro votos.

5. La Comisión adoptará las medidas y las pondrá inmediatamente en aplicación, cuando se ajusten al dictamen del Comité. Si dichas medidas no se ajustaren al dictamen del Comité, o si tal dictamen no se hubiere emitido, la Comisión presentará en seguida al Consejo una proposición sobre las medidas que deban adoptarse. El Consejo adoptará las medidas por mayoría cualificada.

Cuando, transcurrido el plazo de un mes a partir de la fecha en que se haya convocado, el Consejo no hubiere adoptado medida alguna, la Comisión adoptará las medidas propuestas y las pondrá inmediatamente en aplicación, excepto en el caso de que el Consejo se haya pronunciado por mayoría simple contra dichas medidas.

Art. 83. 1: Al principio de cada campaña de comercialización, se establecerá de acuerdo con el procedimiento previsto en el artículo 33 del Reglamento (CEE) número 1035/72 o, según el caso, en los correspondientes artículos de los demás reglamentos por los que se establece la organización común de mercados agrícolas, un plan de previsiones para cada uno de los productos o grupos de productos sometidos al MCI. Para las patatas tempranas, el plan se establecerá con arreglo al procedimiento previsto en el artículo 33 del Reglamento (CEE) número $1035 / 72$, siendo competente para ello el Comité de gestión creado por dicho Reglamento.

Dicho plan se establecerá en principio en función de las previsiones de producción y de consumo en España o en la Comunidad en su composición actual; 
basándose en este plan se establecerá por el mismo procedimiento para la campaña de que se trate un calendario de previsiones relativo al desarrollo del comercio y la fijación de un límite máximo indicativo de importaciones en el mercado correspondiente.

Para el período que va del 1 de marzo de 1986 hasta el comienzo de la campaña de comercialización 1986/1987, se establecerá un plan específico para cada uno de los productos 0 grupos de productos.

2. Las fijaciones sucesivas de los límites indicativos deberán reflejar una cierta progresividad en relación con los flujos comerciales tradicionales, de forma que quede asegurada una apertura equilibrada y gradual del mercado y la total consecución de la libre circulación dentro de la Comunidad, una vez transcurrido el periodo de aplicación de las medidas transitorias.

A estos efectos, se determinará, con arreglo al procedimiento contemplado en el apartado 1 una tasa de crecimiento progresivo anual del límite máximo. En el marco del límite indicativo global, podrán determinarse límites indicativos correspondientes a los diferentes períodos de la campaña de comercialización de que se trate.

Art. 84. 1. Hasta el 31 de diciembre de 1989 se fijará, en el momento del establecimiento del calendario contemplado en el artículo 83, una cantidad «objetivo" para las importaciones en España:

- de los productos contemplados en el punto b) bb) del apartado 2 . del artículo 81 con excepción de los comprendidos en la partida 04.02 del arancel aduanero común,

- de los productos contemplados en el punto b) dd) del apartado 2 del artículo 81 .

2. La cantidad «objetivo» válida para el año 1986 y su progresión para cada uno de los años siguientes en relación con el año precedente serán:

\begin{tabular}{|c|c|c|c|}
\hline $\begin{array}{l}\text { Partida } \\
\text { del arancel } \\
\text { aduanero } \\
\text { común }\end{array}$ & Designación de las mercancías & $\begin{array}{l}\text { Cantidad } \\
\text { "objetivow }\end{array}$ & $\begin{array}{l}\text { Tasa de } \\
\text { progresión }\end{array}$ \\
\hline $\begin{array}{l}\text { bb) } \\
01.02\end{array}$ & $\begin{array}{l}\text { Animales vivos de la especie bovina, } \\
\text { incluso los de género búfalo: } \\
\text { A. de las especies domésticas: } \\
\text { ex II. los demás: } \\
\text { - excepto los animales } \\
\text { para corridas }\end{array}$ & $\begin{array}{l}20.000 \text { t de las } \\
\text { cuales }\end{array}$ & $10 \% 12,5 \% 15 \%$ \\
\hline 02.01 & $\begin{array}{l}\text { Carnes y despojos comestibles de los } \\
\text { animales comprendidos en las parti- } \\
\text { das } 01.01 \text { a } 01.04 \text {, ambas inclusive, } \\
\text { frescos, refrigerados o congelados: } \\
\text { A. Carnes: } \\
\text { II. de bovinos: } \\
\text { B. Despojos: } \\
\text { II. Los demás } \\
\text { b) de bovinos }\end{array}$ & $\left\{\begin{array}{l}\text { animales vivos } \\
12.000 \text { cabezas } \\
\text { - carne fresca y } \\
\text { refrigerada } \\
2.000 \mathrm{t}\end{array}\right.$ & $\cdot$ \\
\hline
\end{tabular}




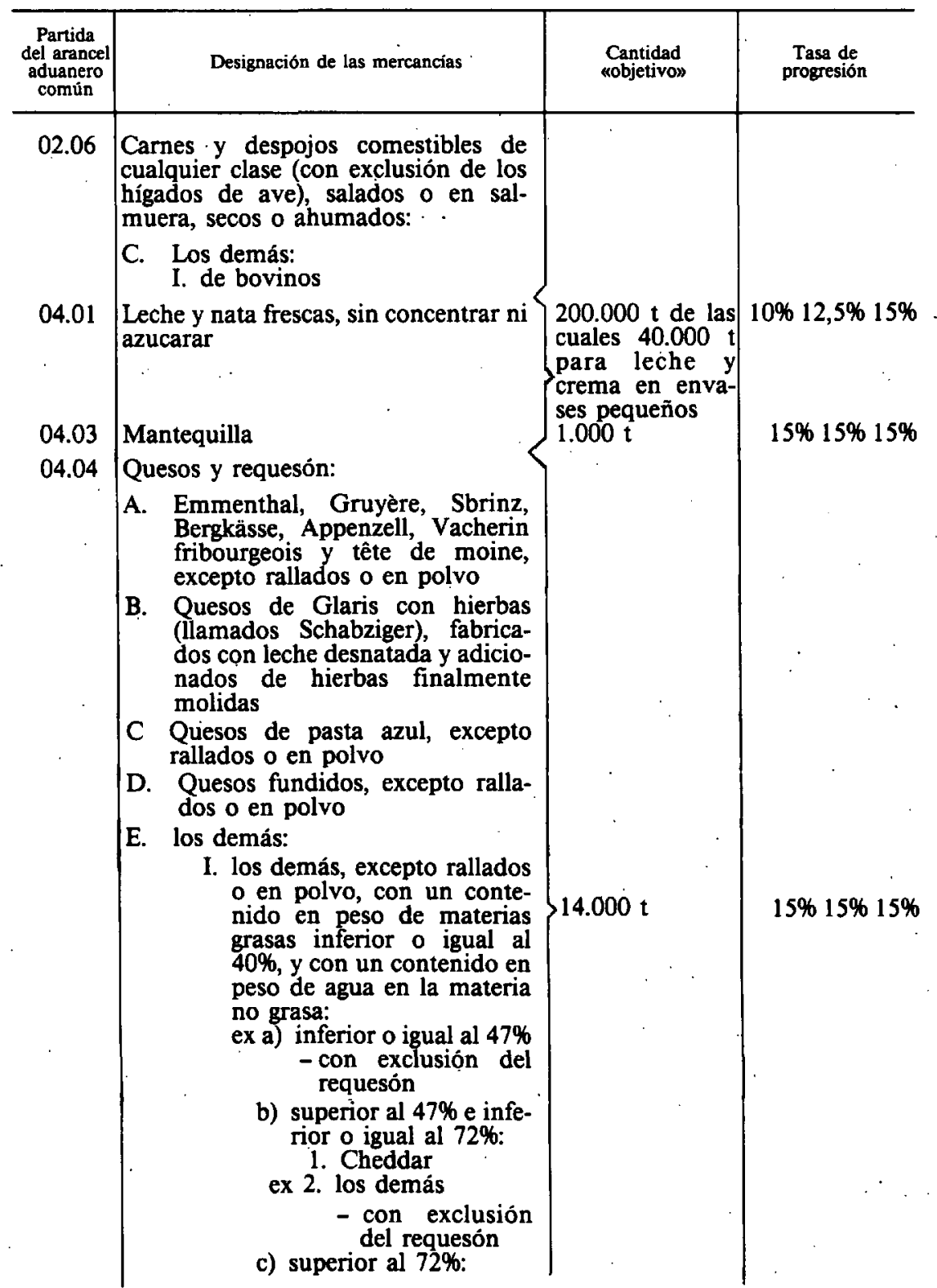




\begin{tabular}{|c|c|c|c|}
\hline $\begin{array}{c}\text { Partida } \\
\text { del arancel } \\
\text { aduanero } \\
\text { común }\end{array}$ & Designación de las mercancias & $\begin{array}{c}\text { Cantidad } \\
\text { «objetivo» }\end{array}$ & $\begin{array}{c}\text { Tasa de } \\
\text { progresión }\end{array}$ \\
\hline . & $\begin{array}{l}\text { ex 1. en envases } \\
\text { inmediatos con } \\
\text { un contenido } \\
\text { neto inferior o } \\
\text { igual a } 500 \mathrm{g:} \\
\text { - con exclusión } \\
\text { del requesón } \\
\text { ex 2. los demás: } \\
\text { - con exclusión } \\
\text {. del requesón } \\
\text { II. los demás: } \\
\text { a) rallados o en polvo . } \\
\text { ex b) los demás: } \\
\text { - con exclusión del } \\
\text { requesón }\end{array}$ & $14.000 \mathrm{t}$ & $15 \% 15 \% 15 \%$ \\
\hline 10.01 & $\begin{array}{l}\text { Trigo y morcajo o tranquillón: } \\
\text { B. Los demás: } \\
\text { exI. Trigo blando y morcajo o } \\
\text { tranquillón: } \\
\text { - Trigo blando panificable }\end{array}$ & $173.000 \mathrm{t}$ & $15 \% 15 \% 15 \%$ \\
\hline
\end{tabular}

Podrá decidirse, con arreglo al procedimiento previsto en el artículo 30 del Reglamento (CEE) núm. 804/68 por el que se establece la organización común de mercados en el sector de la leche y de los productos lácteos o, en su caso, a los articulos correspondientes a las otras organizaciones comunes de que se trate que las cantidades «objetivo» antes mencionadas sean expresadas con arreglo a las exigencias de cada organización común de mercados afectada teniendo en cuenta las modalidades de establecimiento del plan de previsiones contemplado en el artículo 83 .

3. Si fuere necesario se efectuará una repartición de las cantidades «objetivo» antes mencionadas entre los dístintos productos, según el caso, con arreglo al procedimiento contemplado en el apartado 2.

4. En el transcurso de una campaña, la cantidad «objetivo» sólo se podrá superar cuando asi se decida, con arreglo al procedimiento contemplado en el apartado 2.

Al tomar tal decisión, se tendrá en cuenta en particular, a la luz del balance de previsiones para el producto contemplado, la evolución de la demanda interior española, así como el desarrollo de los precios de mercado en España.

Art. 85. 1. Sin perjuicio de 10 dispuesto en el apartado 4 del artículo 84 , en caso de que el estudio de la evolución de los intercambios intracomunitarios revele un incremento significativo de las importaciones realizadas o previsibles y cuando por dicha situación se pueda alcanzar o superar el límite máximo indicativo de importación del producto para la campaña de comercialización en curso o parte de la misma, la Comisión, a-instancia de un Estado miembro o por iniciativa propia, decidirá por un procedimiento de urgencia: 
- las medidas precautorias que sean necesarias, que se aplicarán hasta la entrada en vigor de las medidas definitivas previstas en el apartado 3 ,

- la convocatoria del Comité de gestión del sector correspondiente, para proceder al examen de las medidas apropiadas.

2. Si la situación contemplada en el apartado anterior provocare una perturbación grave de los mercados, un Estado miembro podrá pedir a la Comisión que adopte de manera inmediata las medidas precautorias contempladas en el apartado 1. A tal fin, la Comisión tomará una decisión dentro de las veinticuatro horas siguientes a la recepción de la petición.

Si la decisión de la Comisión no se produjere en dicho plazo, el Estado miembro podrá adoptar las medidas precautorias comunicándolas inmediatamente a la Comisión.

Dichas medidas seguirán siendo aplicables hasta que la Comisión se haya pronunciado acerca de la petición contemplada en el párrafo primero.

3. Las medidas definitivas se adoptarán en el más breve plazo con arreglo al procedimiento previsto en el articulo 33 del Reglamento (CEE) número $1035 / 1972 \mathrm{o}$, en su caso, con arreglo a los artículos correspondientes de los otros Reglamentos sobre organización común de los mercados agricolas.

Tales medidas podrán contener en particular:

a) la revisión del límite máximo indicativo, si el mercado en cuestión no ha sufrido perturbaciones significativas a consecuencia del desarrollo de las importaciones;

b) en función de la gravedad de la situación, la limitación o la suspensión de las importaciones en el mercado de la Comunidad en su composición actual o en el mercado español.

Las medidas restrictivas contempladas en la letra b) sólo podrán tomarse en la medidá y para la duración estrictamente necesarias para poner fin a la perturbación. En lo que respecta a la Comunidad en su composición actual, dichas medidas podrán limitarse a las importaciones con destino a regiones determinadas de la misma, siempre que contengan disposiciones apropiadas que permitan evitar desviaciones de tráfico.

4. En ningún caso la aplicación del MCI podrá dar lugar a que los productos procedentes de España o de la Comunidad en su composición actual reciban un trato menos favorable que aquellos procedentes de los terceros países beneficiarios de la cláusula de nación más favorecida, comercializados en las regiones contempladas.

\section{Subsección 5.-Otras disposiciones}

Art. 86. Cualesquiera existencias de productos que se encuentren en libre práctica en el territorio español el 1 de marzo de 1986 y que sobrepasen en cantidad las que puedan ser consideradas como representativas de unas existencias normales de enlace deberán ser suprimidas por España y a su cargo, en el marco de los procedimientos comunitarios que se establezcan y en los plazos que se determinen en las condiciones previstas en el artículo 91. La noción de existencias normales de enlace será definida para cada producto en función de los criterios y objetivos propios a cada organización común de mercados.

Art. 87. . En el momento de la fijación del nivel de los diferentes importes previstos en el marco de la política agricola común, distintos de los precios contemplados en el articulo 68 , se tendrá en cuenta el montante compensatorio aplicado o, en su defecto, la diferencia de precios registrada o económicamente justificada y, en su caso, la incidencia del derecho de aduana, salvo:

- cuando no exista riesgo de perturbación en los intercambios, o

- cuando el buen funcionamiento de la política agrícola común exija que no se tenga en cuenta o haga que no sea deseable que se tenga en cuenta dicho montante, dicha diferencia 0 dicha incidençia. 
Art. 88. 1. El Consejo, en las condiciones previstas en el artículo 91, establecerá el régimen aplicable por el Reino de España con respecto a la República Portuguesa.

2 Las medidas que se hagan necesarias en los intercambios entre los nuevos Estados miembros y la Comunidad en su composición actual, para la implantación del régimen contemplado en el apartado 1 serán aprobadas, en su caso, en las condiciones previstas en el artículo 91 con arreglo al procedimiento previsto en el apartado 1 del artículo 89.

Art. 89. 1. A no ser que en casos especificos se disponga otra cosa, el Consejo, por mayoria cualificada y a propuesta de la Comisión, adoptará las disposiciones necesarias para la aplicación del presente Capítulo.

Dichas disposiciones podrán prever en particular las medidas adecuadas para evitar las desviaciones del tráfico en los intercambios entre España y los demás Estados miembros.

2. El Consejo, por unanimidad, a propuesta de la Comisión y previa consulta al Parlamento Europeo, podrá proceder a las adaptaciones de las modalidades contenidas en el presente Capitulo que puedan resultar necesarias en caso de una modificación de la normativa comunitaria.

Art. 90. 1. Si fueren necesarias medidas transitorias para facilitar el paso del régimen existente en España al que resulte de la aplicación de la organización común de mercados en las condiciones previstas en el presente Capitulo, en particular si la aplicación del nuevo régimen en la fecha prevista tropezare, respecto de determinados productos, con dificultades apreciables en la Comunidad, tales medidas se adoptarán con arreglo al procedimiento previsto en el artículo 38 del Reglamento número $136 / 66 / C E E$ o, según los casos, en los artículos correspondientes de los otros reglamentos relativos a la organización común de los mercados agricolas. Dichas medidas podrán adoptarse durante un periodo que expirará el 31 de diciembre de 1987, quedando su aplicación limitada a esa fecha.

2. El Consejo, por unanimidad, a propuesta de la Comisión y previa consulta al Parlamento Europeo, podrá prolongar el período previsto en el apartado 1.

Art. 9.1. 1. Las medidas transitorias relativas a la aplicación de los actos en materia de política agricola común y no especificadas en la presente Acta, incluso en el ámbito de las estructuras, que se hagan necesarias por la adhesión, se adoptarán antes de esta última con arreglo al procedimiento contemplado en el apartado 3 y entrarán en vigor, a más tardar, en la fecha de la adhesión.

2. Las medidas transitorias contempladas en el apartado 1 son las que se mencionan en el punto 3 del artículo 75 y en los artículos 80, 86, 88, 126 y 144 .

3. El Consejo, por mayoria cualificada y a propuesta de la Comisión, o la Comisión, con arreglo al procedimiento contemplado en el apartado 1 del artículo 90 , establecerá las medidas transitorias contempladas en el apartado 1 del presente artículo, según que los actos iniciales a los que se refieran hayan sido adoptados por una u otra institución.

Sección II. Disposiciones relativas a determinadas organizaciones comunes de mercados

\section{Subsección 1.-Materias grasas}

Art. 92. 1. En cuanto al aceite - de oliva, las disposiciones de los artículos 68 y 72 se aplicarán al precio de intervención.

2. En el transcurso del periodo transitorio de diez años, el precio así fijado para España será aproximado al nivel del precio común cada año al comienzo de cada campaña de comercialización, segín las modalidades siguientes:

- hasta la entrada en vigor de la adaptación del acervo comunitario, el precio existente en España será aproximado cada año en una veinteava parte de la 
diferencia inicial entre dicho precio y el precio común,

- a partir de la entrada en vigor de la adaptación del acervo, el precio existente en España será corregido en la diferencia existente entre el precio en dicho Estado miembro y el precio común que sean aplicables antes de cada aproximación, dividida por el número de campañas que queden hasta el fin del periodo de aplicación de las medidas transitorias, adaptándose el precio que resulte de este cálculo en proporción a la modificación eventual del precio común para la campaña venidera.

3. El Consejo, con arreglo al procedimiento previsto en el apartado 2 del artículo 43 del Tratado CEE, comprobará si se cumple la condición requerida para la aplicación del segundo guión del apartado 2. La aproximación del precio se efectuará de conformidad con esta última disposición, nada más comenzar la campaña que siga a esa comprobación.

4. El montante compensatorio que resulte de la aplicación de las disposiciones del artículo 72 se adaptará, en su caso, en función de la diferencia entre las ayudas comunitarias al consumo aplicables en la Comunidad en su composición actual y en España.

Art. 93. 1. En cuanto a las semillas oleaginosas, las disposiciones del artículo 68 se aplicarán a los precios indicativos de las semillas de colza, de nabina y de girasol y al precio objetivo de las semillas de soja.

En el caso de las semillas de lino, el precio objetivo aplicable en España el 1 de marzo de 1986 se fijará en función de la diferencia existente entre los precios de los productos competitivos en las rotaciones de los cultivos en España y en la Comunidad en su composición actual, durante un periodo de referencia a determinar. Sin embargo, el precio de objetivo que deba aplicarse en España no podrá sobrepasar el precio común.

2. Durante el período de aplicación de las medidas transitorias, los precios asi fijados para España serán aproximados al nivel de los precios comunes cada año, al comienzo de la campaña de comercialización. La aproximación se llevará a cabo en diez etapas, para lo cual se aplicarán mutatis mutandis las disposiciones del artículo 70 .

3. Los precios de intervención para las semillas de colza, de nabina y de girasol y el precio mínimo para las semillas de soja, aplicables en España, se derivarán respectivamente del precio indicativo y del precio objetivo contemplados en los apartados 1 y 2 , de conformidad con las disposiciones de la organización común de mercado correspondiente.

4. Hasta el 31 de diciembre de 1990 , en los intercambios de productos transformados a base de aceites a los que se refiere el Reglamento número 136/66/CEE, con excepción de los productos a base de aceite de oliva y de los productos de la partida 15.13 del arancel aduanero común se adoptarán medidas apropiadas para tener en cuenta la diferencia de precios de dichos aceites en España y en la Comunidad en su composición actual.

Art. 94. 1. Hasta el 31 de diciembre de 1990 y con arreglo a modalidades a determinar, el Reino de España aplicará un régimen de control:

a) sobre las cantidades de productos contemplados:

- en el punto a), con exclusión de las semillas de soja, correspondientes a la partida ex $12.01 \mathrm{~B}$ del arancel aduanero común,

- en el punto b); con exclusión de los productos de las partidas 15.17 B II y $23.04 \mathrm{~B}$ del arancel aduanero común,

del apartado 2 del artículo 1 del Reglamento número $136 / 66 / \mathrm{CEE}$, en el mercado interior español, con objeto de mantener dichas cantidades en un nivel establecido sobre la base del consumo medio alcanzado en España durante los años 1983 y 1984, nivel que se adaptârá en función de la evolución previsible de las necesidades de abastecimiento; 
b) sobre el nivel de los precios al consumo para los aceites vegetales contemplados en la letra a), asi como para la margarina, de tal modo que -hasta el 31 de diciembre de 1990- se mantenga en principio el nivel de precios, expresados en ECUs, alcanzado durante la campaña $1984 / 1985$.

El régimen de control contemplado en la letra a) incluirá la sustitución, el 1 de marzo de 1986, de los regímenes comerciales aplicados a la importación en España, por un sistema de restricciones cuantitativas a la importación, abierto sin discriminación entre los operadores económicos, tanto con respecto a la Comunidad en su composición actual como con respecto a los terceros países.

2. Hasta el 31 de diciembre de 1990 , la importación en España de semillas de soja estará sujeta al compromiso de exportar los aceites que se obtengan de su trituración y que se produzcan por encima de la cantidad admitida en el mercado español en virtud de la letra $a$ ) del apartado 1.

3. En caso de circunstancias excepcionales, se podrá modificar el régimen de control definido en el presente articulo, para los productos sometidos al mismo, en la medida necesaria para evitar desequilibrios en los mercados de los distintos aceites.

Dichas modificaciones se adoptarán con arreglo al procedimiento previsto en el artículo 38 del Reglamento número 136/66/CEE.

Art. 95. 1. La ayuda comunitaria a la producción de aceite de oliva se aplicará en España desde el 1 de marzo de 1986. Dicha ayuda será fijada por primera vez y durante el periodo de aplicación de las medidas transitorias será aproximada al nivel de la ayuda concedida en la Comunidad en su composición actual, para lo cual se aplicarán mutatis mutandis las disposiciones del artículo 79.

La ayuda comunitaria al consumo para el aceite de oliva se introducirá en España, del 1 de enero de 1991 en adelante, con arreglo a un ritmo a deter- minar, en la medida necesaria para llegar al nivel común al final del periodo de aplicación de las medidas transitorias.

2. La ayuda para las semillas de colza, de nabina, de girasol, de soja y de lino producidas en España será:

- introducida en España desde el comienzo de là primera campaña siguiente a la adhesión e

- incrementada a continuación, durante el periodo de aplicación del régimen de control contemplado en el apartado 1 del artículo 94,

en función de la aproximación, según los casos, del precio indicativo o del precio objetivo aplicable en España hacia el nivel del precio común.

Al finalizar el periodo contemplado en el párrafo que precede, la ayuda concedida en España será igual a la diferencia entre el precio indicativo $u$ objetivo aplicable en dicho Estado miembro y el precio en el mercado mundial, diferencia que será disminuida en la cuantía de la incidencia de los derechos de aduana aplicados por el Reino de España a las importaciones procedentes de los terceros paises.

3. La ayuda para las semillas contempladas en el apartado 2 producidas en España y transformadas en la Comunidad en su composición actual así como la ayuda para las mismas semillas producidas en la Comunidad en su composición actual y transformadas en España se ajustarán para tener en cuenta las respectivas diferencias existentes entre el nivel de los precios de dichas semillas y el de las semillas procedentes de los terceros paises.

4. Además, al calcular la ayuda para las semillas de colza, de nabina y de girasol, se tendrá en cuenta el importe diferencial eventualmente aplicable.

Art. 96. Durante las campañas $1986 / 1987$ a $1994 / 1995$ se fijarán umbrales de garantía específicos para las semillas de colza y de nabina así como para las semillas de girasol producidas en España. 
Dichos umbrales de garantía especificos se determinarán según criterios efectivamente comparables a aquellos adoptados para fijar los umbrales de garantía en la Comunidad en su composición actual, tomándose en consideración la producción más elevada de las registradas en las campañas 1982/1983, $1983 / 1984$ y $1984 / 1985$.

En caso de superarse un umbral de garantía específico, las sanciones de corresponsabilidad se aplicarán con arreglo a las modalidades análogas a las aplicadas en la Comunidad en su composición actual y con el mismo límite máximo.

Art. 97. 1. El Reino de España aplazará, hasta que finalice el régimen de control contemplado en el artículo 94, la aplicación de los regímenes preferenciales, convencionales o autónomos, aplicados por la Comunidad respecto de los terceros países en el sector del aceite de oliva, de las semillas y frutos oleaginosos y de sus productos derivados.

2. Desde el 1 de enero de 1991, el Reino de España aplicará un derecho que reduzca la diferencia entre el tipo del derecho efectivamente aplicado el 31 de diciembre de 1990 y el tipo del derecho preferencial, con arreglo al ritmo siguiente:

- el 1 de enero de 1991, la diferencia quedará reducida al 83,3 por 100 de la diferencia inicial,

- el 1 de enero de 1992, la diferencia quedará reducida al 66,6 por 100 de la diferencia inicial,

- el 1 de enero de 1993, la diferencia quedará reducida al 49,9 por 100 de la diferencia inicial.

- el 1 de enero de 1994, la diferencia quedará reducida al 33,2 por 100 de la diferencia inicial,

- el 1 de enero de 1995, la diferencia quedará reducida al 16,5 por 100 de la diferencia inicial.

El Reino de España aplicará íntegramente los tipos preferenciales a partir del 1 de enero de 1996.
Subsección 2.-Leche y productos lácteos

Art. 98. 1. Hasta la primera aproximación de los precios, los precios de intervención de la mantequilla y de la leche desnatada en polvo que deban aplicarse en España se fijarán a un nivel correspondiente al de los precios registrados en dicho Estado miembro con arreglo al régimen nacional anterior durante un período representativo por determinar.

Posteriormente, la diferencia existente entre.dichos precios y los precios correspondientes calculados de conformidad con las normas previstas en la organización común de mercados sobre la base del precio de garantía de la leche aplicable en España durante el período representativo contemplado en el párrafo primero, será reducida progresivamente de modo que en el momento de la cuarta aproximación sea igual a la mitad de la diferencia inicial y que en el momento de la séptima aproximación quede totalmente suprimida.

Las disposiciones del artículo 70 se aplicarán mutatis mutandis; las disposiciones del artículo 72 serán igualmente aplicables.

Sin embargo, el montante compensatorio para la leche desnatada y la leche desnatada en polvo, destinadas a la alimentación animal, podrá reducirse con arreglo al procedimiento previsto en el artículo 30 del Reglamento (CEE) número 804/68.

2. El montante compensatorio para los productos lácteos distintos de la mantequilla y de la leche desnatada en polvo se fijarán sirviéndose de coeficientes por determinar.

Art. 99. 1. Hasta el 31 de diciembre de 1986, y salvo lo dispuesto en el párrafo segundo, el Reino de España podrá mantener concesiones nacionales de exclusividad a favor de las centrales lecheras en cuanto a la comercialización de la leche fresca pasterizada producida en España.

Dichas concesiones no podrán obstaculizar la libre comercialización en España de la leche fresca pasterizada 
importada procedente de los Estados miembros actuales.

2. El Reino de España comunicará a la Comisión, a más tardar tres meses antes de la fecha de la adhesión, las medidas tomadas en aplicación del apartado 1.

\section{Subsección 3.-Carne de bovino}

Art. 100. El artículo 68 se aplicará al precio de garantía en España y al precio de compra de intervención en la Comunidad en su composición actual, válidos para calidades comparables determinadas sobre la base del modelo comunitario de clasificación de las canales de bovinos pesados. Los artículos 70 y 72 se aplicarán al precio de compra de intervención aplicable en España.

Art. 101. El montante compensatorio para los demás productos contemplados en la letra a) del apartado $1 \mathrm{del}$ artículo 1 del Reglamento (CEE) número $805 / 68$ se fijará sirviéndose de coeficientes por determinar.

Art. 102. Las disposiciones del artículo 79 se aplicarán a la prima para el mantenimiento del censo de vacas nodrizas.

\section{Subsección 4.-Tabaco}

Art. 103. 1. Las disposiciones del artículo $68 \mathrm{y}$, en su caso, del artículo 70 , se aplicarán al precio de intervención fijado para cada variedad o grupo de variedades.

2. El precio objetivo que corresponda al precio de intervención contemplado en el apartado 1 se fijará en España, para la primera cosecha siguiente a la Adhesión, a un nivel que refleje la relación existente entre el precio de objetivo y el precio de intervención, de conformidad con el párrafo segundo del apartado 2 del artículo 2 del Reglamento (CEE) número $727 / 70$ por el que se establece la organización común de mercados en el sector del tabaco en rama.
Subsección 5.-Lino y cânamo

Art. 104. Las disposiciones del artículo 79 se aplicarán a las ayudas para el lino textil y el cáñamo.

\section{Subsección 6.-Lüpulo}

Art. 105. La ayuda a los productores de lúpulo contemplada en el artículo 12 del Reglamento (CEE) número 1696/71 se aplicará en .España íntegramente desde la primera cosecha siguiente a la adhesión.

\section{Subsección 7.-Semillas}

Art. 106. Las disposiciones del artículo 79 se aplicarán a las ayudas para las semillas contempladas en el artículo 3 del Reglamento (CEE) número 2358/71.

\section{Subsección 8.-Gusanos de seda}

Art. 107. Las disposiciones del artículo 79 se aplicarán a la ayuda para los gusanos de seda.

\section{Subsección 9.-Azúcar}

Art. 108. Las disposiciones de los artículos 68,70 y 72 se aplicarán al precio de intervención del azúcar blanco y al precio de base de la remolacha.

Sin embargo, el montante compensatorio se corregirá, en la medida necesaria para el buen funcionamiento de la organización común de mercados, en la incidencia de la cotización para.la compensación de los gastos de almacenamiento.

Art. 109. Para el azúcar bruto y para los productos distintos de las remolachas frescas, mencionados en la letra $b$ ) del apartado 1 del artículo 1, así como para los productos mencionados en las letras $d$ ) y $f$ del apartado 1 del artículo $1 \mathrm{del}$ Reglamento (CEE) número $1785 / 81$, por el que se establece la organización común de mercados en el sector del azúcar, se podrán fijar montantes compensatorios en la medida necesaria para evitar cualquier riesgo de perturba- 
J ción en los intercambios entre la Comunidad en su composición actual y España.

En tal' caso, los montantes compensatorios se derivarán del montante compensatorio aplicable al producto de base correspondiente, sirviéndose de coeficientes por determinar.

Art. 110. Hasta el 31 de diciembre de 1995 a más tardar, el Reino de España estará autorizado para otorgar una ayuda nacional de adaptación a los productores de remolacha de azúcar. Dicha ayuda sólo se otorgará para la remolacha A y para la remolacha $B$, según la definición del Reglamento (CEE) número $1785 / 81$ por el que se establece la organización común de mercados en el sector del azúcar. La cuantia de esta ayuda no podrá exceder del 23,64 por 100 del precio de base de la remolacha fijado por la Comunidad para la campaña de comercialización de que se trate.

\section{Subsección 10.-Cereales}

Art. 111. 1. En el sector de los cereales, las disposiciones de los articulos 68,70 y 72 se aplicarán a los precios de intervención.

2. Respecto de los cereales para los que no se haya fijado precio de intervención, el montante compensatorio se derivará del montante compensatorio aplicable a la cebada, tomando en consideración la relación existente entre los precios de umbral de los cereales contemplados.

3. Para los productos contemplados en la letra $\mathcal{C}$ del artículo 1 del Reglamento (CEE) número $2727 / 75$ por el que se establece la organización común de mercados en el sector de cereales, el montante compensatorio se derivará del montante compensatorio aplicable a los cereales de los que proceden aquéllos, mediante coeficientes a determinar.

Art. 112. El peso especifico minimo de la cebada que podrá ser aceptada para la intervención en España queda fijado respectivamente:
- para el período que abarca desde el 1 de marzo de 1986 hasta el final de la campaña $1986 / 1987$, en $60 \mathrm{~kg} / \mathrm{hl}$,

- para la campana 1987/1988, en 61 $\mathrm{kg} / \mathrm{hl}$,

- para la campaña 1988/1989, en 62 $\mathrm{kg} / \mathrm{hl}$.

La depreciación de la que será objeto el precio de intervención de la cebada aplicable en España será:

- de un 4 por 100 para el período que abarca del 1 de marzo de 1986 hasta el final de la campaña $1986 / 1987$,

- de un 3 por 100 para la campaña $1987 / 1988$,

- de un 2 por 100 para la campaña 1988/1989.

Art. 113. Las disposiciones del artículo 79 se aplicarán a la ayuda para el trigo duro contemplada en el artículo 10 del Reglamento (CEE) número $2727 / 75$.

\section{Subsección 11.-Carne de porcino}

Art. 114. 1. El montante compensatorio aplicable por kilogramo de cerdo sacrificado se calculará a partir de los montantes compensatorios aplicables a la cantidad de cereales pienso necesaria para la producción, en la Comunidad, de un kilogramo de carne de cerdo. Sin embargo, durante las cuatro primeras campañas siguientes a la adhesión, este montante no se aplicará.

2. En cuanto a los productos distintos del cerdo sacrificado, contemplados en el apartado 1 del artículo 1 del Reglamento (CEE) número $2759 / 75$ por el que se establece la organización común de mercados en el sector de la carne de porcino, el montante compensatorio se derivará del mencionado en el apartado 1 del presente artículo, sirviêndose de coeficientes por determinar, cuando éste se aplique.

3. Hasta el 31 de diciembre de 1989 , de surgir el peligro de que se efectuen en España intervenciones demasiado masivas por razón de las ayudas al almacenamiento privado 0 , de ser necesario, de 
las compras públicas decididas en virtud del artículo 20 del Reglamento (CEE) número $2759 / 75$, se podrá decidir, con arreglo al procedimiento previsto en el artículo 24 de dicho Reglamento, tomar las medidas restrictivas necesarias para las importaciones, de cualquier procedencia, en este Estado miembro, en el sector de la came de porcino.

\section{Subsección 12.-Huevos}

Art. 115. 1. El montante compensatorio aplicable por kilogramo de huevos con cáscara se calculará tomando como base los montantes compensatorios aplicables a la cantidad de cereales pienso necesaria para la producción, en la Comunidad, de un kilogramo de huevos con cáscara.

2. El montante compensatorio aplicable por huevo para incubar se calculará tomando como base los montantes compensatorios aplicables a la cantidad de cereales pienso necesaria para la producción, en la Comunidad, de un huevo para incubar.

3. El montante compensatorio para los productos mencionados en la letra $b$ ) del apartado 1 del artículo 1 del Reglamento (CEE) número $2771 / 75$ por el que se establece la organización común de mercados en el sector de los huevos se derivará del de los huevos con cáscara, sirviéndose de coeficientes a determinar.

\section{Subsección 13.-Carne de ave de corral}

Art. 116. 1. El montante compensatorio aplicable por kilogramo de ave de corral sacrificada se calculará tomando como base los montantes compensatorios aplicables a la cantidad de cereales pienso necesaria para la producción, en la Comunidad, de un kilogramo de ave de corral sacrificada, diferenciada por especies.

2. El montante compensatorio aplicable por pollito se calculará tomando como base los montantes compensatorios aplicables a la cantidad de cereales pienso necesaria para la producción, en la Comunidad, de un pollito.
3. Para los productos contemplados en la letra d) del apartado 2 del articulo 1 del Reglamento (CEE) número $2777 / 75$ por el que se establece la organización común de mercados en el sector de la carne de ave de corral; el montante compensatorio se derivará del montante compensatorio de la carne sacrificada, sirviéndose de coeficientes a determinar.

\section{Subsección 14.-Arroz}

Art. 117. 1. En el sector del arroz las disposiciones de los artículos 68,70 y 72 se aplicarán al precio de intervención del arroz cáscara («paddy»).

2. El montante compensatorio para el arroz descascarillado será el montante compensatorio aplicable al arroz cáscara («paddy»), convertido por medio del tipo de conversión contemplado en el artículo 1 del Reglamento número 467/67/CEE.

3. El montante compensatorio para el arroz blanqueado será el montante compensatorio aplicable al arroz descascarillado, convertido por medio del tipo de conversión contemplado en el artículo 1 del Reglamento número 467/67/CEE.

4: El montante compensatorio para el arroz semiblanqueado será el montante compensatorio aplicable al arroz blanqueado, convertido por medio del tipo de conversión contemplado en el artículo 1 del Reglamento número 467/67/CEE.

5. El montante compensatorio para los productos mencionados en la letra $c$ ) del apartado 1 del artículo 1 del Reglamento (CEE) número $1418 / 76$ por el que se establece la organización común de los mercados en el sector del arroz, se derivará del montante compensatorio aplicable a los productos de que procedan aquéllos, sirviéndose de coeficientes a determinar.

6. El montante compensatorio para los partidos de arroz se fijará a un nivel que tenga en cuenta la diferencia existente entre el precio de abastecimiento en España y el precio de umbral. 


\section{Subsección 15.-Frutas y hortalizas transformadas}

Art. 118. Para los productos que se beneficien del régimen de ayudas previsto en el artículo 3 del Reglamento (CEE) número $516 / 77$ por el que se establece la organización común de mercados en el sector de los productos transformados a base de frutas y hortalizas, se aplicarán en España las disposiciones siguientes:

1. Hasta la primera aproximación de los précios contemplados en el artículo 70, los precios mínimos contemplados en el artículo 3 ter del Reglamento (CEE), número $516 / 77$ queda establecido sobre la base:

- del precio fijado en España bajo el régimen nacional anterior para el producto destinado a la transformación, o

- a falta de dicho precio, de los precios pagados en España a los productores para el producto destinado a la transformación registrados durante un periodo representativo por determinar.

2. En caso de que el precio minimo a que se refiere el apartado 1:

- sea inferior al precio común, el precio en España será modifícado al comienzo de cada una de las campañas de comercialización siguientes a la adhesión, según las modalidades previstas en el artículo 70 ,

- sea superior al precio común, este último precio será el que se tendrá en cuenta para España a partir de la adhesión.

3. a) Durante las cuatro primeras campañas siguientes a la adhesión, para los productos transformados a base de tomates, el importe de la ayuda comunitaria concedida en España se derivará de la ayuda calculada para la Comunidad en su composición actual, habida cuenta de la diferencia de los precios mínimos a la producción que resulten de la aplicación del apartado 2; antes de que esta última ayuda sea eventualmente reducida como consecuencia de haberse sobrepasado el umbral de garantía fijado para dichos productos en la Comunidad en su composición actual.

En caso de que se sobrepase el umbral en la Comunidad en su composición actual, si ello se revelase necesario para garantizar unas condiciones normales de competencia entre las industrias españolas y las de la Comunidad, se decidirá, de acuerdo con el procedimiento previsto en el artículo $20 \mathrm{del}$ Reglamento (CEE) número $516 / 77$ que un montante compensatorio, como máximo igual a la diferencia entre la ayuda fijada para España y la que se habría derivado de la ayuda comunitaria fijada, será aplicado con arreglo a la letra a) del punto 3 del artículo 72 y percibido por el Reino de España sobre las exportaciones hacia los terceros paises. Sin embargo, al finalizar el régimen contemplado por el Reglamento (CEE) número $1320 / 85$, no se percibirá ningún montante compensatorio cuando se aporte la prueba de que el producto español no se ha beneficiado de la ayuda comunitaria concedida en España.

En ningún caso la ayuda aplicable en España podrá ser superior al importe de la ayuda concedida en la. Comunidad en su composición actual.

b) Durante las cuatro primeras campañas siguientes a la adhesión, la concesión de la ayuda comunitaria en España estará limitada, para cada campaña, a una cantidad de productos transformados correspondientes a un volumen de tomates frescos de:

- 370.000 toneladas para la fabricación de concentrado de tomates,

- 209.000 toneladas para la fabricación de tomates pelados enteros,

- 88.000 toneladas para la fabricación de otros productos a base de tomates.

Al finalizar dicho periodo, las cantidades arriba fijadas, adaptadas en función de la eventual modificación de los umbrales comunitarios que se hubiere producido en el mismo periodo, serán 
tomadas en consideración para la fijación de los umbrales comunitarios.

4. Durante la quinta y la sexta campaña siguientes a la adhesión, para los productos a base de tomates y para los demás productos durante las seis campañas siguientes a la adhesión, el importe de la ayuda comunitaria concedida en España se derivará de la ayuda establecida por la Comunidad en su composición actual, habida cuenta de la diferencia de los precios mínimos que resulten de la aplicación del apartado 2 .

Sin embargo, para los productos que no sean a base de tomates, si los gastos de transformación registrados en España para un producto durante un período representativo a determinar, con arreglo al régimen nacional anterior, son inferiores en al menos un 10 por 100 a los gastos de transformación válidos en la Comunidad en su composición actual, la ayuda concedida en España por ese producto se establecerá teniendo en cuenta igualmente la diferencia de gastos de transformación registrados. Los gastos de transformación registrados en España serán progresivamente aproximados a los gastos registrados en la Comunidad en su composición actual, con arreglo a las mismas normas que las contempladas en el artículo 70 para la aproximación de precios.

5. La ayuda comunitaria se aplicará en España integramente a partir del comienzo de la séptima campaña de comercialización siguiente a la adhesión.

6. Para los melocotones en almíbar, durante las cuatro primeras campañas siguientes a la adhesión, la concesión de la ayuda comunitaria en España estará limitada a una cantidad de 80.000 toneladas de producto acabado expresado en peso neto.

7. A los efectos de la aplicación del artículo 1, el precio minimo, los gastos de transformación y la ayuda válidos en la Comunidad en su composición actual se refieren a los importes válidos en la Comunidad en su composición actual con exclusión de Grecia.
Art. 119. El precio minimo y la compensación financiera aplicables en España, previstos en los artículos 2 y 3 del Reglamento (CEE) número 2601/69 por el que se prevén medidas especiales para favorecer el recurso a la transformación para determinadas variedades de naranjas y en los artículos 1 y 2 del Reglamento (CEE) número $1035 / 77$ por el que se prevén medidas particulares para favorecer la comercialización de los productos transformados a base de limones, quedan fijados de la siguiente forma:

1. Hasta la primera aproximación de los precios contemplados en el artículo 70, el precio mínimo aplicable se establecerá sobre la base de los precios pagados en España a los productores de citricos destinados a la transformación, registrados durante un período representativo a determinar. La compensación financiera será la de la Comunidad en su composición actual, diminuida en su caso en la diferencia entre, por una parte, el precio mínimo común $\mathrm{y}$, por otra, el precio minimo aplicable en España.

2. Para las fijaciones siguientes el precio mínimo aplicable en España se aproximará al precio minimo común según las disposiciones previstas en el. artículo 70 . La compensación financiera aplicable en España en el momento de cada etapa de aproximación será la misma de la Comunidad en su composición actual, disminuida en su caso, en la diferencia entre, por una parte, el precio mínimo común $y$, por otra parte, el precio minimo aplicable en España.

3. Sin embargo, cuando el precio minimo que resulte de la aplicación del apartado 10 del apartado 2 sea superior al precio minimo común, este último precio podrá ser tenido en cuenta definitivamente para España.

4. Durante las cuatro primeras campañas siguientes a la adhesión, las cantidades que podrán beneficiarse de una ayuda a la transformación estarán limitadas a una cantidad de productos trans- 
formados correspondientes a una cantidad de materias primas de:

- 30.000 toneladas para las naranjas de la variedad «blanca común»,

- 7.600 toneladas para las naranjas de las variedades pigmentadas,

- 26.000 toneladas para los limones.

\section{Subsección 16.-Forrajes secos}

Art. 120. 1. El precio de objetivo contemplado en el artículo 4 del Reglamento (CEE) número $1117 / 78$ por el que se establece la organización común de mercados en el sector de forrajes deshidratados, aplicable en España el 1 de marzo de 1986, se fijará sobre la base de las diferencias existentes entre los precios de los productos competitivos en la rotación de los cultivos en España y en la Comunidad en su composición actual en el transcurso de un periodo de referencia a determinar.

El artículo 70 se aplicará al precio de objetivo calculado con arreglo al párrafo primero. Sin embargo, el precio objetivo que deba aplicarse en España no podrá sobrepasar el precio objetivo común.

2. La ayuda complementaria aplicable en España se ajustará en un importe igual a:

- la diferencia existente, en su caso, entre el precio objetivo en España y el precio objetivo común, afectada del porcentaje contemplado en el apartado 2 del articulo 5 del Reglamento (CEE) número $1117 / 78$, y

- la incidencia de los derechos de aduana aplicados en España a la importación de dichos productos procedentes de los terceros países.

3. Las disposiciones del artículo 79 se aplicarán a la ayuda global contemplada en el articulo 3 del Reglamento (CEE) número $1117 / 78$.

Subsección 17.-Guisantes, habas, haboncillos $y$ altramuz dulce

Art. 121. 1. Para los guisantes, habas, haboncillos y altramuz dulce utilizados en la fabricación de alimentos para animales, las disposiciones de los artículos 68 y 70 se aplicarán al precio de umbral de activación. Para los demás guisantes, habas y haboncillos, el precio de objetivo aplicable en España el 1 de marzo de 1986 será fijado en función de la diferencia existente entre los precios de los productos competitivos en la rotación de los cultivos en España y en la Comunidad en su composición actual en el transcurso de un periodo de referencia por determinar.

El artículo 70 se aplicará al precio de objetivo de esos productos. Sin embargo, el precio de objetivo que deba aplicarse en España no podrá sobrepasar el precio de objetivo común.

2. Para los productos cosechados en España y utilizados en la fabricación de alimentos para animales a que se refiere el Reglamento (CEE) número 1431/82 por el que se prevén medidas especiales respecto de los guisantes, las habas, los haboncillos y el altramuz dulce, el importe de la ayuda contemplada en el apartado 1 del artículo 3 de dicho Reglamento será disminuido en la incidencia de la diferencia existente, en su caso, entre el precio de activación aplicado en España y el precio de activación común.

Sin perjuicio de la aplicación del párrafo primero, el importe de la ayuda de que se trate para un producto transformado en España será disminuido en la cuantia de la incidencia de los derechos de aduana aplicados en España a la importación de las tortas de soja procedentes de los terceros paises.

Las deducciones contempladas en los párrafos primero y segundo resultarán de la aplicación de los porcentajes contemplados en el apartado 1 del artículo 3 del Reglamento (CEE) número 1431/82.

3. El importe de la ayuda contemplada en el apartado 2 del artículo 3 del Reglamento (CEE) número $1.431 / 82$ para los guisantes, habas y haboncillos cosechados en España y utilizados en la alimentación humana o animal para una utilización distinta de la prevista en el apartado 1 del mismo articulo, será disminuido en un importe igual a la 
diferencia existente, en su caso, entre el precio de objetivo aplicado en España y el precio de objetivo común.

Sin perjuicio de la aplicación del párrafo primero, el importe de la ayuda de que se trate para un producto transformado en España será disminuido en la cuantía de la incidencia de los derechos de aduana aplicados en España a la importación de dichos productos procedentes de los terceros paises.

\section{Subsección 18.-Vino}

Art. 122. 1. Hasta la primera de las aproximaciones de los precios contemplados en el artículo 70:

- el precio de orientación aplicable en España para el vino blanco de mesa será fijado de forma tal que la relación entre el precio de compra del vino de mesa para entregar con destino a la destilación obligatoria en ese Estado miembro y el precio de orientación sea de 50 por 100 ,

- el precio de orientación aplicable en España al vino tinto de mesa se derivará del precio de orientación para el vino blanco de mesa, aplicando la misma relación que exista en la Comunidad en su composición actual entre los precios de orientación de los vinos de mesa del tipo AI y RI,

- el precio de compra de los vinos de mesa contemplado en el primer guión se fijará al nivel del precio de la destilación obligatoria de regulación aplicado en España durante un periodo representativo a determinar,

- el precio mínimo garantizado contemplado en el artículo 3 bis del Reglamento (CEE) número 337/79 será igual al 72 por 100 del precio de orientación de cada tipo de vino de mẹsa,

- el precio del vino objeto de la destilación contemplada en el artículo 12 bis del Reglamento (CEE) número 337/79 será igual:

al 80 por 100 del precio de orientación del vino blanco de mesa al 81,5 por 100 del precio de orientación del vino tinto de mesa.
2. El artículo 70 se aplicará a los precios de orientación de los vinos de mesa. Durante las campañas 1986/1987 a 1990/1991:

- la relación entre el precio de orientación y los precios contemplados en los guiones tercero, cuarto y quinto del apartado 1, aplicables en España, se alineará progresivamente, por etapas iguales, sobre la relación existente entre esos precios en la Comunidad en su composición actual,

- sin perjuicio de lo dispuesto en el primer guión del apartado 6 del articulo 41. del Reglamento (CEE) número $337 / 79$, en lo que se refiere a la relación entre el precio de orientación y el precio del tercer guión del apartado 1 , el nivel de precio correspondiente al 40 por 100 contemplado en el segundo guión del apartado 6 del artículo 41 del Reglamento (CEE) número $337 / 79$ se alcanzará según el ritmo contemplado en el primer guión del presente apartado.

Art. 123. 1. Se crea un mecanismo de montantes reguladores sobre las importaciones en la Comunidad en su composición actual de los productos contemplados en el apartado 2, procedentes de España, que sean objeto de la fijación de un precio de referencia en el marco de la organización común de mercados.

2. El mecanismo se regirá por las normas siguientes:

a) Para los vinos de mesa, se percibirá un montante regulador igual a la diferencia existente entre los precios de orientación en España y en la Comunidad en su composición actual. Sin embargo, el nivel de dicho montante podrá ser adaptado, con arreglo al procedimiento previsto en el articulo 67. del Reglamento (CEE) número 337/79, para tener en cuenta la situación de los precios de mercado apreciada según las distintas categorias de vinos y en función de su calidad.

b) Para determinados vinos de denominación de origen y para los 
demás productos, que pudieran crear perturbaciones en el mercado, se podrá fijar un montante regulador con arreglo al procedimiento contemplado en la letra a). Dicho montante regulador se derivará del que sea aplicable a los vinos de mesa, con arreglo a modalidades por determinar.

3. A montante regulador se le fijará un límite máximo, situado en un nivel que garantice condiciones de irato no menos favorables que las vigentes con arreglo al régimen anterior a la adhesión. A tal fin, este montante se calculará de tal modo que el montante que se obtenga añadiendo al precio de orientación aplicable en España para el producto contemplado el montante regulador y los derechos de aduana que le sean aplicables, no. exceda del precio de referencia en vigor para ese producto en el curso de la campaña de que se trate.

4. Habida cuenta de la situación particular del mercado de los distintos productos contemplados en el apartado 2 , se podrá decidir, con arreglo al procedimiento previsto en el artículo $67 \mathrm{del}$ Reglamento (CEE) número $337 / 79$, la fijación de un montante regulador para las exportaciones de uno o varios de dichos productos desde la Comunidad en su composición actual hacia España.

Este montante se fijará en un nivel que permita garantizar una corriente de intercambios normal entre la Comunidad en su composición actual y España, que no cree perturbaciones en el mercado español para los productos contemplados.

5. El montante regulador concedido será financiado por la Comunidad con cargo al Fondo Europeo de Orientación y de Garantia Agricolas, Sección Garantía.

Art. 124. A los efectos dè la aplicación, hasta la expiración de la campaña 1989/1990, de la destilación obligatoria contemplada en el articulo 41 del Reglamento (CEE) número $337 / 79$, la suma de las producciones medias de vinos de mesa y de productos obtenidos en fases anteriores de la elaboración del vino de mesa, destinados a la vinificación, obtenidos en las distintas regiones de producción en España en el transcurso de las tres campañas consecutivas de referencia, queda fijada en 27,5 millones de hectolitros.

Art. 125. 1. Durantè el periodo del 1 de marzo de 1986 al 31 de diciembre de 1989 estará permitida en el territorio español la mezcla de un vino apto para la producción de un vino blanco de mesa o de un vino blanco con un vino apto para la producción de un vino tinto de mesa o con un vino tinto de mesa. El producto resultante de dicha mezcla no podrá circular más que en el territorio español.

2. Durante el periodo contemplado en el apartado 1 , se prohíbe la mezcla en la Comunidad en su composición actual, de vinos españoles, distintos de los vinos blancos de mesa, con los vinos de los otros Estados miembros, salvo casos excepcionales por determinar.

Durante este periodo los vinos espanooles anteriormente indicados sólo podrán ser objeto de intercambios con los demás Estados miembros si están sometidos a disposiciones que permitan determinar su origen y seguir sus movimientos comerciales.

Art. 126. 1. Hasta el final del año 1995 , los vinos de mesa que tengan su origen en las superficies que estén plantadas de vid el 1 de enero de 1985 en las regiones de Asturias, Cantabria, Galicia, Guipúzcoa y Vizcaya, y de las cuales se deberá establecer la lista en las condiciones previstas en el artículo 91 , podrán tener un grado alcohólico adquirido no inferior a 7 por 100 vol.

Para los vinos cuyo grado alcohólico adquirido sea inferior a 9 por 100 vol. la indicación de ese grado deberá figurar en el etiquetado.

2. Los vinos de mesa contemplados en el apartado precedente no podrán circular más que en el territorio español.

Art. 127. Hasta el 31 de diciembre de 1990 los vinos de meșa producidos en España y puestos al consumo en el 
mercado de dicho Estado miembro podrán tener un contenido en acidez total no inferior a $3,5 \mathrm{~g} / \mathrm{l}$, expresada en ácido tartárico.

Art. 128. Hasta el final de la campaña 1992/1993, el importe de la ayuda a favor de los mostos de uva concentrados y de los mostos de uva concentrados rectificados, que se contempla en el artículo 14 del Reglamento (CEE) número $337 / 79$, aplicable en Espàna será fijado teniendo en cuenta la diferencia entre los costos, para ese Estado miembro, el aumento artificial del grado alcohólico natural obtenido por medio de los productos antes mencionados y el aumento artificial del grado alcohólico natural obtenido por medio de sacarosa.

Art. 129. Hasta el 31 de diciembre de 1995 , se autorizará en los territorios del Reino Unido y de Irlanda la utilización de las denominaciones compuestas "British Sherry", "drish Sherry" y "Cyprus Sherry». En el transcurso del año 1995, el Consejo reconsiderará esta medida y, con arreglo al procedimiento del articulo 43 del Tratado CEE, adoptará cualquier modificación de la misma, a propuesta de la Comisión y teniendo en cuenta los intereses de todas las partes interesadas.

\section{Subsección 19.-Carne de ovino $y$ caprino}

Art. 130. En el sector de la carne de ovino, el artículo 68 será aplicable al precio de base.

\section{Sección III.-Frutas y hortalizas}

Art. 131. Las frutas y hortalizas reguladas en el Reglamento (CEE) número 1035/72 estarán sometidas a una transición específica en dos fases:

- La primera fase, llamada de verificación de convergencia, empezará el 1 de marzo de 1986 y terminará el 31 de diciembre de 1989,

- La segunda fase, empezará el 1. de enero de 1990 y terminará el 31 de diciembre de 1995.
El paso de la primera a la segunda fase será automático.

\section{Subsección 1.-Primera fase}

A) Mercado interior español

Art. 132. 1. Durante la primera fase el Reino de España estará autorizado a mantener, para los productos contemplados en el artículo 131, la normativa en vigor con arreglo al régimen nacional anterior para la organización de su mercado interior agrícola en las condiciones previstas en los artículos 133 a 135.

2. Por lo tanto y como excepción a las disposiciones del articulo 394, la aplicación en España de la normativa comunitaria relativa a la organización del mercado interior queda aplazada hasta el término de la primera fase.

Además queda aplazada hasta el final de la primera fase, la aplicación en la Comunidad en su composición actual y en España, de las modificaciones hechas a la normativa comunitaria en virtud del artículo 396.

Art. 133. 1. Con objeto de permitir al sector español de frutas y hortalizas su integración en el marco de la política agrícola común de forma armoniosa y completa al término de la primera fase, el Reino de España adaptará progresivamente la organización de su mercado interior en función de los objetivos generales definidos en el apartado 2 .

2. Los objetivos generales que deberán realizarse serán los siguientes:

- Aplicación progresiva de las normas de calidad al conjunto de los productos afectados y aplicación estricta de las exigencias inherentes a las mismas.

- Desarrollo de las agrupaciones de productores en el sentido contemplado en la normativa comunitaria.

- Creación de un organismo y constitución de una infraestructura material y humana aptas para realizar las operaciones de intervención pública previstas por la normativa comunitaria. 
- Creación de una red que registre diariamente las cotizaciones en los mercados representativos que deberá establecerse en función de los diferentes productos.

- Liberalización de los intercambios con vistas a establecer un régimen de libre competencia y de libre acceso al mercado español y adaptación de las «ordenaciones comerciales sectoriales» referidas a la exportación para hacerlas compatibles con las exigencias de la libre circulación.

3. Con objeto de favorecer la realización de los objetivos generales:

a) La normativa comunitaria en el sector socioestructural, incluyendo la relativa a las organizaciones de productores, se aplicará en España desde el momento de la adhesión;

b) La Comunidad participará en la financiación de las operaciones de intervención llevadas a cabo en España durante la primera fase por las organizaciones de productores para los productos que cumplan las normas comunes de calidad.

Sin embargo, la proporción de dicha participación financiera comunitaria estará limitada para cada producto a la proporción de la producción cubierta por las organizaciones de productores en España, reconocidas por la Comisión como conformes a la normativa comunitaria, tanto en lo referente a las condiciones de constitución como a las de funcionamiento.

Cada campaña la Comisión constatará el grado de cobertura contemplado en el párrafo precedente; con tal objeto procederá a efectuar controles sobre el terreno, en colaboración con las autoridades españolas.

Art. 134. 1. A fin de realizar los objetivos generales, la Comisión elaborará, durante el periodo de interinidad, en estrecha colaboración con las autoridades españolas, un programa de acción.
2. Posteriormente, la Comisión seguirá atentamente la evolución de la situación en España a la vista de:

- Los progresos alcanzados en la realización de los objetivos fijados.

- Los resultados obtenidos en la ejecución de las medidas estructurales, horizontales o específicas.

3. La Comisión expresará su opiniôn sobre dicha evolución en los informes que remitirá al Consejo:

- Al final del periodo de interinidad con vistas a establecer un balance de la evolución producida antes de la fecha de la adhesión,

- Con la suficiente antelación antes del final del cuarto año de la adhesión,

- En cualquier momento que la misma juzgue útil o necesario.

4. Habida cuenta especialmente de las deliberaciones del Consejo sobre los informes contemplados en el apartado 3 , la Comisión podrá formular, si fuere necesario, recomendaciones al Reino de España referentes a las accio- nes que deberian ser llevadas a cabo con vistas a la realización de los objetivos fijados.

Art. 135. Durante la primera fase, el Reino de España aplicará las siguientes diciplinas:

1. Una disciplina de precios:

a) Desde el momento de la adhesión el Reino de España fijará los precios institucionales para los productos para los cuales existan ya precios comunes según los criterios más próximos posibles a los definidos en el marco de la organización común de mercados en función de un período de referencia por determinar a un nivel correspondiente a la realidad económica.

b) Cuando esos precios españoles, expresados en ECUs, sean inferiores o iguales a los precios comunes, los aumentos anuales de precios no podrán, en principio, sobrepasar, en valor, el aumento de los precios comunes. 
En ningún caso podrán los precios españoles sobrepasar el nivel de los precios comunes.

c) Cuando los precios españoles, expresados en ECUs, sean superiores a los precios comunes, no podrán ser aumeritados respecto de su nivel anterior. Además, el Reino de España adaptará sus precios en la medida necesaria para evitar un incremento de la diferencia entre sus propios precios y los precios comunes.

d) El Reino de España podrá ajustar sus precios en caso de que las intervenciones en el mercado alcancen un volumen no justificado. En ese caso, el precio ajustado sustituirá el precio original para la aplicación. de las normas contempladas anteriormente en las letras b) y c).

e) La Comisión velará por el respeto de las normas contempladas más arriba. Si se rebasare el nivel de precios que resulte de la aplicación de estas normas, tal circunstancia no se tendrá en cuenta para la determinación del nivel de precios que han de servir de nivel de base para la aproximación de los precios en el transcurso de la segunda fase contemplada en el artículo 148.

2. Una disciplina de ayudas:

En virtud de dicha disciplina se autoriza al Reino de España a mantener durante la primera fase sus ayudas nacionales.

Sin embargo, en el transcurso de dicho periodo, el Reino de España velará para que se efectúe un cierto desmantelamiento de las ayudas nacionales no conformes con el Derecho comunitario y para que se introduzca progresivamente en la organización de su mercado interior, el plan de las ayudas comunitarias sin que el nivel de dichas ayudas sobrepase el nivel común.

3. Una disciplina de producción:

En virtud de dicha disciplina el Reino de España aplicará las mismas disciplinas de producción que las que, en su caso, sean aplicables en los demás Estados miembros o en los Estados miem- bros que se encuentren en una situación comparable respecto de dicha disciplina.

B) Régimen aplicable en los intercambios entre la Comunidad en su composición actual y España

Art. 136. 1. Sin perjuicio de las disposiciones contempladas en el artículo 75 y en los artículos 137 a 139 , se autoriza al Reino de España a mantener en sus intercambios con la Comunidad en su composición actual, durante la primera fase, y para los productos contemplados en el artículo 131, el régimen en vigor antes de la adhesión para esos intercambios, tanto para la importación como para la exportación.

2. Durante la primera fase, sin perjuicio de lo dispuesto en el apartado 2 del artículo 75 y en el artículo 140, la Comunidad en su composición actual aplicará a la importación de los productos contemplados en el artículo 131 procedentes de España el régimen que haya aplicado respecto de España antes de la adhesión.

3. Durante la primera fase, sin perjuicio de lo dispuesto en el artículo 141, la Comunidad en su composición actual aplicará a la exportación de los productos contemplados en el artículo $131 \mathrm{con}$ destino a España el régimen que haya aplicado a la exportación hacia terceros paises.

Art. 137. 1. 'Sin perjuicio de las disposiciones del apartado 2, el Reino de España suprimirá, a partir del 1 de marzo de 1986, la aplicación de cualquier restricción cuantitativa y de cualquier medida de efecto equivalente asi como cualquier exacción de efecto equivalente a un derecho de aduana a la importación de los productos contemplados en el articulo 131 procedentes de la Comunidad en su composición actual.

2. Hasta el 31 de diciembre de 1989 , el Reino de España podrá mantener restricciones cuantitativas a la importación procedente de la Comunidad en su composición actual para los productos siguientes: 


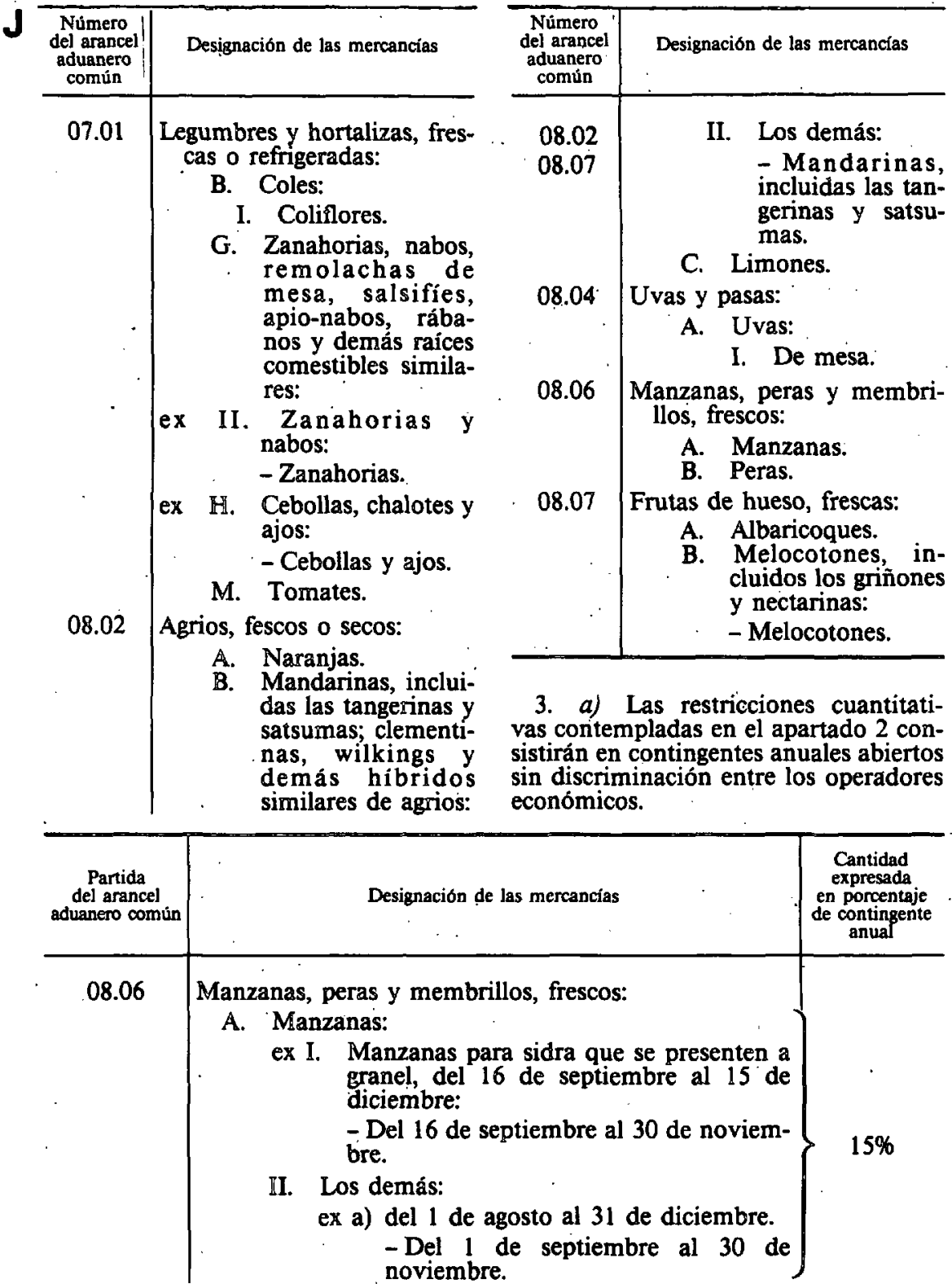




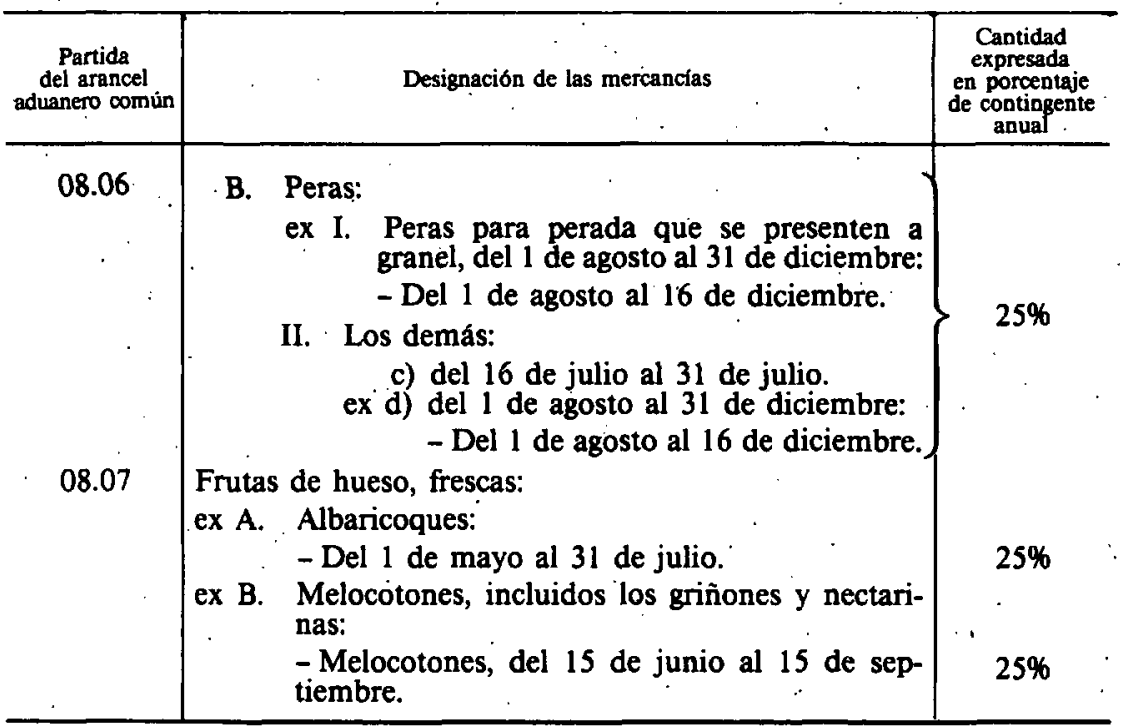

b) El contingente inicial para cada producto, expresado en volumen, quedará fijado:

- bien en el 3 por 100 del promedio de la producción anual española en los tres últimos años anteriores a la adhesión para los que se disponga de estadística;

- bien en el promedio de las importaciones españolas realizadas durante los tres últimos años antes de la adhesión para las que haya estadísticas disponibles, si este último criterio lleva a un volumen más elevado.

c) El ritmo mínimo de aumento progresivo de los contingentes será del 10 por 100 al comienzo de cada año.

El aumento se añadirá a cada contingente y el aumento siguiente se calculará a partir de la cifra total obtenida.

d) Cuando las importaciones realizadas en España durante dos años consecutivos sean inferiores al 90 por 100 del contingente anual abierto, se suprimirán las restricciones cuantitativas vigentes en España. e) Para el periodo que se extiende del 1 de marzo al 31 de diciembre de 1986 el contingente aplicable será igual al contingente inicial disminuido en un sexto.

4. En el marco de las restricciones cuantitativas contempladas en el apartado 2, las importaciones en España de los productos del cuadro anterior se someterán a la aplicación de un calendario con cantidades de importaciones definidas en relación al contingente fijado para cada año.

Art. 138. Durante la primera fase, el Reino de España no concederá, en principio, ayudas o subvenciones a la exportación, para los productos contemplados en el artículo 131 exportados con destino a los Estados miembros actuales.

Sin embargo, si se apreciara la necesidad de la concesión de tales ayudas o subvenciones, su montante estará limitado como máximo a la diferencia de los precios institucionales o, a falta de éstos, de los precios registrados en España y en la Comunidad en su composición actual 
y, llegado el caso, a la incidencia de los derechos de aduana.

La fijación de dichas ayudas o subvenciones sólo podrá producirse después del desarrollo del procedimiento de consulta contemplado en el artículo 142.

Art. 139. 1. . Desde el 1 de marzo de 1986, el Reino de España suprimirá la aplicación de cualquier restricción cuantitativa o de cualquier medida de efecto equivalente a la exportación de los productos contemplados en el artículo 131 con destino a la Comunidad en su composición actual.

2. Sin embargo, durante la primera fase, el Reino de España podrá mantener las ordenaciones comerciales sectoriales que aplica a la exportación, adaptándolas durante esta fase para hacerlas compatibles con las exigencias de la libre circulación al final de dicha fase.

Art. 140. 1. No obstante 10 dispuesto en el apartado 2 del artículo 136, los posibles gravámenes compensatorios a la importación de los produetos procedentes de España, que resulten de la aplicación del Reglamento (CEE) número $1035 / 72$, serán reducidos en:

- 2 por 100 , el primer año,

- 4 por 100 , el segundo año,

- 6 por 100 , el tercer año,

- 8 por 100 , el cuarto año,

siguientes a la fecha de la adhesión.

2. En los intercambios entre la Comunidad en su composición actual y los terceros paises, durante la primera fase, no se tendrán en cuenta las cotizaciones de estos productos españoles a los efectos del cálculo de los precios de referencia.

Art. 141. 1. Durante la primera fase, la Comunidad en su composición actual no concederá en principio restituciones a la exportación para los productos contemplados en el artículo 131 con destino a España.

Sin embargo, si se apreciara la necesidad de la concesión de tales restituciones, su cuantía estará limitada como máximo a la diferencia de los precios institucionales 0 , a falta de éstos, de los precios registrados en la Comunidad en su composición actual y en España y, en su caso, a la incidencia de los derechos de aduana.

La fijación de dichas restituciones sólo podrá producirse después del desarrollo del procedimiento de consulta contemplado en el articulo 142.

2. Las restituciones mencionadas en el presente artículo serán financiadas por la Comunidad con cargo al Fondo Europeo de Orientación y de Garantía Agricola, Sección Garantía.

Art. 142. La aplicación por el Reino de España de las ayudas o de las subvenciones contempladas en el artículo 138 o por la Comunidad de las restituciones contempladas en el artículo 141 estará subordinada a consultas previas que se desarrollarán según el procedimiento siguiente:

1. Cualquier proyecto de fijación de: - subvenciones a la exportación de España a la Comunidad en su composición actual o con destino a terceros paises 0

- restituciones a la exportación de la Comunidad en su composición actual con destino a España

será objeto de un cambio de impresiones en el marco de las reuniones periódicas del Comité de Gestión creado por el Reglamento (CEE) número 1035/72.

2. El representante de la Comisión someterá a examen el proyecto mencionado en el apartado 1; este examen tratará especialmente del aspecto económico de las exportaciones proyectadas asi como de la situación y el nivel de los precios en el mercado español, en el mercado de la Comunidad en su composición actual o en el mercado mundial.

3. El Comité emitirá un dictamen acerca del proyecto en un plazo que podrá determinar el presidente en función de la urgencia de la fijación. El Comité se pronunciará por mayoría de cincuenta y cuatro votos.

El dictamen se comunicará inmediatamente a la autoridad competente para la fijación, a saber, según el caso, el Reino de España o la Comisión. 
C) Régimen aplicable en los intercambios entre España y los térceros paises

Art. 143. Para los productos contemplados en el artículo 131 y con sujeción a las disposiciones mencionadas en el artículo 137, el Reino de España aplicará, desde el 1 de marzo de 1986 , la normativa comunitaria relativa al régimen aplicable a la importación en la Comunidad de productos importados procedentes de los terceros paises.

Sin embargo, en materia de precios de referencia, el Reino de España aplicará a las importaciones procedentes de los terceros paises el régimen que le aplique la Comunidad en su composición actual en virtud del apartado 1 del articulo 140 .

Art: 144. Hasta el 31 de diciembre de 1989, el Reino de España podrá mantener restricciones cuantitativas a la importación procedente de los terceros países para los productos contemplados en el apartado 2 del artículo 137, conforme a las modalidades por determinar según el procedimiento contemplado en el artículo 91.

Art. 145. Para los productos contemplados en el artículo 131, el Reino de España estará autorizado para aplàzar hasta el comienzo de la segunda fase la aplicación progresiva a la importación de las preferencias concedidas por via autonóma o convencional por la Comunidad a determinados terceros paises.

Art. 146. 1. Para los productos contemplados en el artículo 131 y con sujeción a las disposiciones contempladas en el apartado 2, el Reino de España estará autorizado para mantener durante la primera fase en la exportación con destino a terceros países, el régimen vigente antes de su adhesión para dichos intercambios.

2. El importe de las ayudas o de las subvenciones concedidas, en su caso, por el Reino de España en la exportación con destino a terceros países deberá limitarse a lo que sea estrictamente necesario para garantizar la comerciali- zación del producto correspondiente en el mercado de destino.

Dichas ayudas o subvenciones sólo podrán aplicarse después del desarrollo del procedimiento contemplado en el articulo 142. Las consultas se referirán, en particular, al aspecto económico de las exportaciones previstas, a los precios tenidos en cuenta para su cálculo y a la situación de los mercados de procedencia y de destino.

\section{Subsección 2.-Segunda fase}

Art. 147. A partir de la segunda fase se aplicará enteramente en España la normativa comunitaria relativa a los productos contemplados en el artículo 131 , con sujeción a las disposiciones de los artículos $75,81,82,83$ y 85, así como de los artículos 148 a 153 .

Art. 148. 1. Sin perjuicio de las disposiciones de la letra e) del apartado 1. del artículo 135, hasta la primera aproximación de los precios contemplados en el artículo 149 , los precios que han de aplicarse en España a partir del 1 de enero de 1990 se fijarán según las normas previstas en la organización común de mercados correspondiente, en el nivel de los precios fijados en España al término de la primera fase.

2. En caso de que al comienzo de la segunda fase se haya comprobado que la diferencia entre el nivel de precios para un producto en España y el del precio común sea minima, el precio común podrá ser aplicado en España para el producto considerado.

La diferencia de precio se considerará mínima cuando sea inferior 0 igual al 3 por 100 del precio común.

Art. 149. Si la aplicación de las disposiciones del apartado 1 del artículo 148 condujere en España a un nivel de precios diferente del de los precios comunes, los precios aplicables en España se aproximarán a los precios comunes a partir del comienzo de la campaña 1990/1991 en seis etapas, aplicándose mutatis mutandis las disposiciones del artículo 70 . 
Los precios comunes se aplicarán en España en el momento de la sexta aproximación.

Art. 150. Las disposiciones del apartado 1 del artículo 76 y de los artículos 80, 87 y 90 se aplicarán en España desde el 1 de enero de 1990.

Sin embargo, la fecha del 31 de diciembre de 1987 que figura en el artículo 90 será sustituida por la de 31 de diciembre de 1991.

Art. 151: En caso de que se cree una ayuda en el marco de la política agricola común en el transcurso de la primera fase, se introducirá dicha ayuda en España o el nivel de la ayuda análoga existente en España se aproximará al nivel común en seis etapas, aplicándose por analogia las disposiciones previstas en el artículo 79.

Art. 152. 1.. Durante la segunda fase se aplicará un mecanismo de compensación para la importación en la Comunidad en su composición actual, de las frutas y hortalizas procedentes de España para las que se haya fijado un precio de referencia con respecto a los terceros paises.

2. Este mecanismo se regirá por las normas siguientes:

a) Se efectuará una comparación entre un precio de oferta del producto español, calculado según se indica en la letra $b$ ), y un precio de oferta comunitario. Este último precio se calculará. anualmente:

- Sobre la base de la media aritmética de los precios al productor de cada Estado miembro de la Comunidad en su composición actual más los gastos de transporte y de embalaje que recaen sobre los productos desde las regiones de producción hasta los centros de consumo representativos de la Comunidad,

- Habida cuenta de la evolución de los costes de producción.

Los precios al productor mencionados corresponderán a la media de las cotiza- ciones registradas durante los tres años que precedan a la fecha de fijación del precio de oferta comunitario.

El precio de oferta comunitario. no podrá sobrepasar el nivel del precio de referencia aplicado respecto de terceros países.

b) El precio de oferta español se calculará, cada día de mercado, sobre la base de las cotizaciones representativas registradas en la fase importador-mayorista o reducidas a ésta, en la Comunidad en su composición actual. El precio de los productos procedentes de España será igual a la cotización representativa más baja o a la media de las cotizaciones representativas más bajas registradas para el 30 por 100 al menos de las cantidades de la procedencia referida, comercializadas en el conjunto de los mercados representativos para los que se dispone de cotizaciones. Esta o estas cotizaciones serán disminuidas previamente:

- En el derecho de aduana calculado con arreglo a la letra c),

- En la cuantia del montante corrector eventualmente establecido con arreglo a la letra $d$ ).

c) El derecho de aduana que deberá deducirse de las cotizaciones del producto español será el derecho del arancel aduanero común reducido progresivamente cada año al comienzo de la campaña en un sexto de su importe; sin embargo, para el año 1990 la reducción se producirá el 1 de enero.

d) $\mathrm{Si}$ el precio del producto español calculado con arreglo a la letra $b$ ) fuere inferior al precio de oferta comunitario contemplado en la letra a), el Estado miembro importador percibirá, en el momento de la importación en la Comunidad en su composición actual, un montante corrector igual a la diferencia entre estos dos precios.

e) El montante corrector se percibirá hasta que las comprobaciones efectuadas demuestren que el precio del producto español es igual o superior al 
precio comunitario contemplado en la letra a).

3. Si el mercado español resultare perturbado a causa de las importaciones procedentes de la Comunidad en su composición actual, podrán decidirse medidas apropiadas, que pueden prever en particular la aplicación de un montante corrector según modalidades a determinar, en lo que se refiere a las importaciones en España de frutas y hortalizas procedentes de la Comunidad en su composición actual para las que se haya fijado un precio de referencia.

Art. 153. 1. El Reino de España aplicará de forma progresiva en la importación, de los productos contemplados en el artículo 131 desde el 1 de enero de 1990, las preferencias concedidas por vía autónoma o convencional por la Comunidad a determinados terceros países.

2. A este fin el Reino de España aplicará un derecho que reduzca la diferencia entre el derecho aplicado efectivamente el 31 de diciembre de 1989 y el derecho preferencial, según el siguiente ritmo:

- el 1 de enero de 1990, la diferencia se reducirá al 85,7 por 100 de la diferencia inicial,

- el 1 de enero de 1991, la diferencia se reducirá al 71,4 por 100 de la diferencia inicial,

- el 1 de enero de 1992, la diferencia se reducirá al 57,1 por 100 de la diferencia inicial,

- el 1 de enero de 1993, la diferencia se reducirá al 42,8 por 100 de la diferencia inicial,

- el 1 de enero de 1994, la diferencia se reducirá al 28,5 por 100 de la diferencia inicial,

- el 1 de enero de 1995, la diferencia se reducirá al 14,2 por 100 de la diferencia inicial.

El Reino de España aplicará íntegramente los derechos preferenciales el $1 \mathrm{de}$ enero de 1996.

\section{CAPITULO IV}

\section{Pesca}

\section{Sección I.-Disposiciones generales}

Art. 154. 1. Salvo disposiciones en contrario del presente capítulo. las normás previstas por la prsente Acta serán aplicables al sector de la pesca.

2. Las disposiciones del apartado 2 del artículo 89 y del artículo 90, serán aplicables a los productos de la pesca.

Art. 155. 1. Salvo lo dispuesto en el apartado 2 y sin perjuicio de lo dipuesto en el Protocolo número -2, la política común de pesca no será aplicable a las islas Canarias ni a Ceuta y Melilla.

2. El Consejo, por mayoria cualificada y a propuesta de la Comisión,

a) establecerá las medidas comunitarias estructurales que podrian ser adoptadas en favor de los territorios contemplados en el apartado 1;

b) establecerá las modalidades apropiadas para tomar en consideración, en todo o en parte, los intereses de los territorios contemplados en el apartado 1 con ocasión de las decisiones que adopte; en cada caso, a fin de preparar las negociaciones por parte de la Comunidad con vistas a la adopción o conclusión de acuerdos de pesca con los terceros países así como los intereses específicos de esos territorios en el seno de los convenios internacionales relativos a la pesca, en los cuales la Comunidad sea parte contratante.

3. El Consejo, por unanimidad y a propuesta de la Comisión, determinará, en su caso, las posibilidades y condiciones de acceso mutuo a las zonas de pesca respectivas y a sus recursos.

\section{Sección II.-Acceso a las aguas y a los recursos}

Art. 156. Con objeto de lograr su integración en el régimen comunitario de conservación y de gestión de los recursos de pesca creado por el Reglamento (CEE) número 170/1983, el 
DA-1985-1986, núms. 206-207. Acta relativa.a las condiciones de .Adhesión del Reino de Espa...

acceso a las aguas sometidas a la soberanía o a la jurisdicción de los Estados miembros actuales cubiertas por el Consejo Internacional de Exploración del Mar (CIEM) por barcos que naveguen bajo pabellón español y que estén matriculados $y / 0$ registrados en un puerto situado en el territorio al que se aplica la política común de pesca, estará sometido al régimen definido en la presente sección.

Art. 157. Los barcos contemplados en los artículos 158,159 y 160 serán los únicos que podrán faenar en las zonas y en las condiciones que en ellos se fijan.

Art. 158. 1. 300 barcos determinados con sus características técnicas en la lista nominal que figura en el anexo IX, llamada «lista de base», podrán ser autorizados a faenar en las divisiones CIEM Vb, VI, VII, VIII a, b, d, con exclusión, durante el periodo que se extiende hasta el 31 de diciembre de 1995 , de la zona situada al sur de los $56^{\circ} 30^{\prime}$ de latitud norte, al este de los $12^{\circ}$ de longitud oeste y al norte de los $50^{\circ} 30^{\prime}$ de latitud norte.

2. Sólo 150 barcos tipo de los cuales 5 sólo podrán dedicarse a la pesca de especies distintas de las demersales, incluidos en la lista de base, estarán autorizados para faenar simultáneamente, siempre que figuren en una lista periódica establecida por la Comisión y con los límites siguientes:
a) 23 en las divisiones CIEM Vb y VI,
b) 70 en la división CIEM VII,
c) 57 en la división CIEM VIII a, b, $d$.

Por barco tipo se entiende un barco cuya potencia al freno sea igual a 700 $\mathrm{CV}$. Los índices de conversión para los barcos de otras potencias son los siguientes:

\begin{tabular}{c|c}
\hline Potencia & Coeficiente \\
\hline $\begin{array}{c}\text { Inferior a } 300 \mathrm{CV} \ldots \ldots \ldots .6 \\
\text { Igual o superior a } 300 \mathrm{CV}\end{array}$ & 0,57 \\
pero inferior a $400 \mathrm{CV}$. & 0,76 \\
$\begin{array}{c}\text { Igual o superior a } 400 \mathrm{CV} \\
\text { pero inferior a } 500 \mathrm{CV} . .\end{array}$ & 0,85
\end{tabular}

\begin{tabular}{|c|c|}
\hline Potencia & Cocticiente \\
\hline $\begin{array}{l}\text { Igual o superior a } 500 \mathrm{CV} \\
\text { pero inferior a } 600 \mathrm{CV} \\
\text { Igual o superior a } 600 \mathrm{CV} \\
\text { pero inferior a } 700 \mathrm{CV} \\
\text { Igual o superior a } 700 \mathrm{CV} \\
\text { pero inferior a } 800 \mathrm{CV} \\
\text { Igual o superior a } 800 . \mathrm{CV} \\
\text { pero inferior a } 1.000 \mathrm{CV} \\
\text { Igual o superior a } 1.000 \mathrm{CV} \\
\text { pero inferior a } 1.200 \mathrm{CV} \\
\text { Superior a } 1.200 . \ldots \ldots \ldots \\
\text { Palangreros distintos de .los } \\
\text { contemplados en la letra } b \text { ) } \\
\text { del articulo } 160 \ldots . . . \ldots \\
\text { Palangreros distintos de los } \\
\text { contemplados en la letra } b \text { ) } \\
\text { del articulo } 160 \text { y equipa- } \\
\text { dos con un dispositivo que } \\
\text { permita el cebado automá- } \\
\text { tico o la recogida mecánica } \\
\text { de los palangres ........ }\end{array}$ & $\begin{array}{l}0,90 \\
0,96 \\
1,00 \\
1,07 \\
1,11 \\
2,25\end{array}$ \\
\hline
\end{tabular}

Para la aplicación de estos índices de conversión a los barcos que efectúen las operaciones de pesca llamadas «parejas» y «trios», se sumarán las potencias de los motores de los barcos que participen en dichas operaciones.

3. Las eventuales adaptaciones de la lista de base que resulten de la retirada del servicio de barcos, que tengan lugar antes de la adhesión, por razón de fuerza mayor, serán aprobadas, antes del 1 de enero de 1986 con arreglo al procedimiento del artículo 14 del Reglamento (CEE) número 170/1983. Esas adaptaciones no podrán afectar el número de barcos y su distribución entre cada una de las categorías ni implicar un aumento del tonelaje global o de la potencia total para cada categoria; además, los barcos que los sustituyan sólo podrán ser elegidos entre los enumerados en la lista que figura en el anexo $X$.

Art. 159. 1. El número de barcos tipo contemplados en el apartado $2 \mathrm{del}$ artículo 158 podrá aumentarse en función de la evolución de las posibilidades globales de pesca asignadas a España 
para las poblaciones sometidas al régimen del total admisible de capturas, denominado en lo sucesivo «TAC», con arreglo al procedimiento previsto en el artículo 11 del Reglamento (CEE) número $170 / 1983$.

2. A medida que los barcos contemplados en la lista de base sean retirados del servicio y eliminados de la lista de base, podrán sustituirse por barcos de la misma categoría a razón de la mitad de la potencia de los barcos eliminados, hasta que la lista de base quede estable- cida a un nivel en relación a los recursos pesqueros asignados de forma que permita una explotación normal de los mismos.

Las condiciones de sustitución contempladas en el párrafo primero sólo se aplicarán en la medida en que la capacidad de la flota de la Comunidad en su composición actual no sea aumentada en las aguas comunitarias del Atlántico.

Art. 160: 1. Se autorizan las actividades de pesca especializadas que a continuación se indican:

\begin{tabular}{|c|c|c|c|c|}
\hline Tipo de pesca & Zona & $\begin{array}{l}\text { Número total } \\
\text { de barcos } \\
\text { autorizados } \\
\text { (lista básica) }\end{array}$ & $\begin{array}{c}\text { Número } \\
\text { de barcos } \\
\text { autogizados } \\
\text { a faenar } \\
\text { simultáneamente } \\
\text { (lista periódica) }\end{array}$ & $\begin{array}{l}\text { Periodo de autorizacion } \\
\text { de la pesca }\end{array}$ \\
\hline 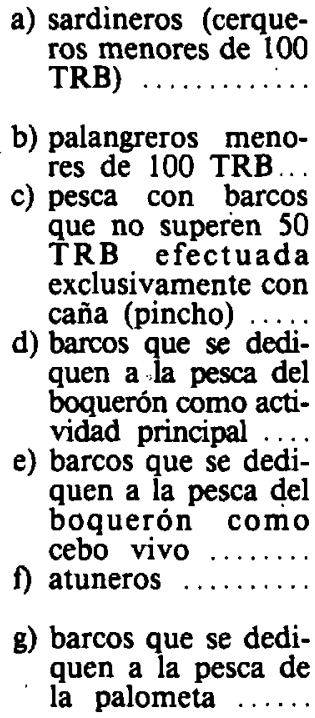 & $\begin{array}{l}\text { VIII a, b, d } \\
\text { VIII a, b, d } \\
\text { VIII a, b, d } \\
\text { todas } \\
\text { las zonas } \\
\text { VII g h, j, k }\end{array}$ & - & $\begin{array}{c}160 \\
120 \\
\text { ilimitada }\end{array}$ & $\begin{array}{c}\begin{array}{c}1 / 1-28 / 2 \\
\text { 1/7-31/12 } \\
\text { todo el año }\end{array} \\
\text { todo el año } \\
1 / 3-30 / 6 \\
1 / 7-31 / 10 \\
\text { todo el año } \\
1 / 10-31 / 12\end{array}$ \\
\hline
\end{tabular}

2. Desde el 1 de enero de 1986 el conjunto de las disposiciones relativas al ejercicio de las actividades de pesca contempladas en el apartado 1 permanecerán idénticas a las que fueren aplica- bles inmediatamente antes de la entrada en vigor de la presente Acta.

Sin embargo, las actividades de pesca contempladas en la letra $c$ ) del apartado 1 podrán llevarse a cabo en la divi- 
sión CIEM de que se trate en cualquier lugar más allá de las 12 millas marinas calculadas a partir de las líneas de base.

Art. 161. 1. La cuota que deba asignarse a España del TAC de las especies sometidas a TAC y a cuotas se fijará por especie y por zona de la manera siguiente:

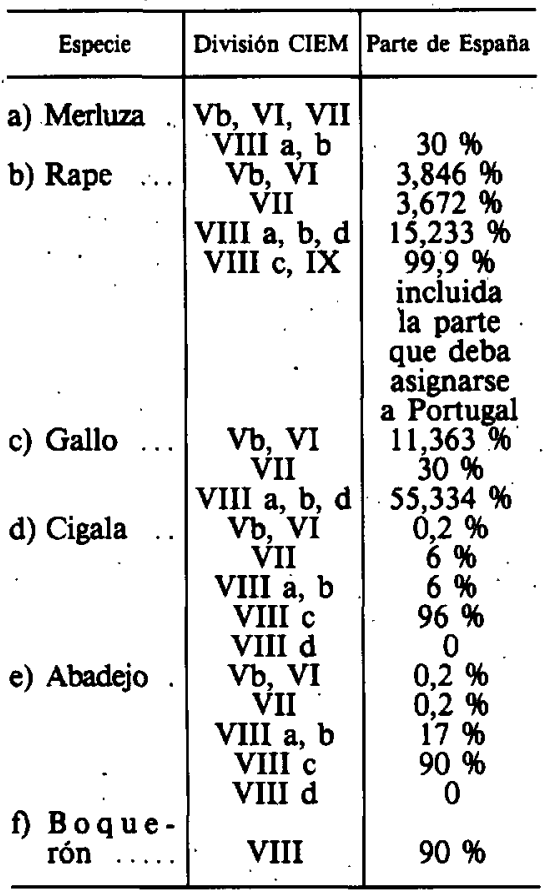

2. Como suplemento al cupo de los TAC de merluza contemplado en la letra a) del apartado 1 , se asignará anualmente, durante un periodo de tres años a partir del 1 de enero de 1986 , una cantidad suplementaria de 4.500 toneladas.

En el caso en que el nivel global de estos TAC sobrepasara 45.000 toneladas, esa cantidad suplementaria a tanto alzado se reducirá de tal forma que se complete el nivel de la cuota global asignada a España hasta llegar a 18.000 toneladas.
3. La cantidad a asignar a España de las especies sometidas a TAC sin reparto en cuotas se fijará a tanto alzado por especie y zona como sigue:

\begin{tabular}{c|c|c}
\hline Especiè & Zona CIEM & $\begin{array}{c}\text { Parte de } \\
\text { España } \\
\text { Tone- } \\
\text { ladas }\end{array}$ \\
\hline a) Bacaladilla & $\begin{array}{l}\text { Vb, VI, VII, } \\
\text { VIII a, b, d } \\
\text { Vb, VI, VII, } \\
\text { VIII a, b, d }\end{array}$ & 30.000 \\
b) Jurel ........ & 31.000 \\
\hline
\end{tabular}

4. Las posibilidades de pesca determinadas para España y las cuotas que de ellas resulten para los demás Estados miembros de la Comunidad se fijarán anualmente de conformidad con el artículo 11 del Reglamento (CEE) número 170/1983.

Art. 162. Antes del 31 de diciembre de 1992, la Comisión presentará al Consejo un informe sobre la situación y las perspectivas de la pesca en la Comunidad en función de la aplicación de los artículos 158 y 161 . Sobre la base de ese informe se efectuarán antes del 31 de diciembre de 1993, con arreglo al procedimiento previsto en el artículo $43 \mathrm{del}$ Tratado CEE, las adaptaciones que resulten necesarias, incluidas las relativas al acceso a zonas distintas de las mencionadas en el apartado 1 del artículo 158, que surtirán efecto el 1 de enero de 1996.

Art. 163. 1. Las autoridades españolas establecerán listas de base para las actividades de pesca contempladas en las letras a) y b) del apartado 1 del artículo 160 y una lista en que se indiquen las características técnicas de cada barco para las demás actividades de pesca contempladas en el apartado 1 del artículo 160.

Las autoridades españolas someterán a la Comisión proyectos de listas periódicas, contempladas en el apartado 2 del artículo 158 y en el apartado 1 del artículo 160 . 
2. Para los barcos contemplados en el artículo 158 y en la letra $g$ ) del apartado 1. del artículo 160, las listas periódicas cubrirán un período minimo de un mes.

Para las demás categorías de barcos, las modalidades de actividad serán fijadas de conformidad con el apartado 2 del artículo 160 y con arreglo al procedjmiento contemplado en el párrafo segundo del apartado 3 del presente articulo.

Previa verificación, dichas. listas serán aprobadas por la .Comisión, que las transmitirá a las autoridades españolas y a las autoridades de control de los demás Estados miembros afectados.

3. Las disposiciones que tengan por objeto garantizar el respeto, por parte de los operadores, de la normativa prevista en el presente artículo, incluyendo los que contemplen la posibilidad de no autorizar el barco de que se trate a pescar durante un periodo determinado, serán aprobadas antes del 1 de enero de 1986 con arreglo al procedimiento previsto en el artículo 11 del Reglamento (CEE) número 170/1983.

Las modalidades técnicas que sean necesarias para garantizar la aplicación de los artículos 156 a 162 asi como las incluidas en el anexo XI serán aprobadas antes del 1 de enero de 1986 con arreglo al procedimiento previsto en el articulo 14 del Reglamento (CEE) número 170/1983.

Art: 164. 1. El número de barcos que naveguen con pabellón de un Estado miembro actual, autorizados a faenar en aguas del océano Atlántico sometidos a la soberanía o a la jurisdicción del Reino de España cubiertos por el CIEM, se fijará anualmente:

a) Para las especies sometidas a TAC y cuotas, en función de las posibilidades de pesca asignadas;

b) Para las especies no sometidas a TAC y cuotas, teniendo en cuenta la estabilidad relativa y la necesidad de garantizar la conservación de las poblaciones.

2. Las actividades de pesca especializada de los barcos que naveguen con pabellón de un Estado miembro actual en las aguas mencionadas en el apartado 1 se ejercerán dentro de los mismos limites cuantitativos y con arreglo a las mismas modalidades de acceso y de control que los fijados para los barcos españoles autorizados a faenar en las zonas de pesca de la Comunidad en su composición -actual, respetando las demás disposiciones relativas a la conservación de los recursos.

3. Las normas generales de aplicación del presente artículo y en particular la fijación anual del número de barcos se aprobarán con arreglo al procedimiento previsto en el articulo 11 del Reglamento (CEE) número 170/1983 y por vez primera antes del ' 1 de enero de 1986:

4. Las modalidades de acceso del presente artículo se establecerán con arreglo al procedimiento del artículo 14 del Reglamento (CEE) número $170 / 1983$ antes del 1 de enero de 1986.

Art. 165. 1. Para su integración en el régimen comunitario de conservación y de gestión de los recursos de pesca, creado por el Reglamento (CEE) número $170 / 1983$, el acceso de los barcos que naveguen con pabellón de Portugal a las aguas sometidas a la soberanía o a la jurisdicción del Reino de España, cubiertas por el CIEM y el Comité de Pesca del Atlántico CentroEste (COPACE) estará sometido, hasta el 31 de diciembre de 1995, al régimen definido en los apartados 2 a 8, sin perjuicio de las disposiciones particulares contempladas en el articulo 155 .

2. Las actividades siguientes podrán ser llevadas a cabo por los barcos contemplados en el apartado 1 como actividad de pesca principal: 


\begin{tabular}{|c|c|c|c|c|c|c|}
\hline Especies & $\begin{array}{c}\text { Canti- } \\
\text { dad } \\
(t)\end{array}$ & Zonas & $\begin{array}{c}\text { Artes de pesca } \\
\text { autorizados }\end{array}$ & $\begin{array}{l}\text { Número total } \\
\text { de barcos } \\
\text { autorizados } \\
\text { (lista de base) }\end{array}$ & $\begin{array}{c}\text { Número } \\
\text { de barcos } \\
\text { autorizados } \\
\text { a faenar } \\
\text { simultáneamente } \\
\text { (lista periódica) }\end{array}$ & $\begin{array}{c}\text { Periodo de pesca } \\
\text { autorizado }\end{array}$ \\
\hline \multicolumn{7}{|l|}{ Especies demersales } \\
\hline - Merluza & 850 & $\begin{array}{l}\text { C I E M } \\
\text { VIII + IX + COPACE } \\
\text { (costa continental) }\end{array}$ & arrastre & $\therefore$ & 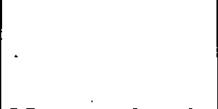 & todo el año \\
\hline - Las demás & & $\begin{array}{l}\text { C I E M } \\
\text { VIII + IX + COPACE } \\
\text { (costa continental) }\end{array}$ & . & $\begin{array}{l}\text { Norte de la } \\
\text { frontera Rio } \\
\text { Miño: } 17 . \\
\text { Este de la } \\
\text { frontera. Rio } \\
\text { Guadiana: } 4\end{array}$ & $\begin{array}{c}\text { Norte de la } \\
\text { frontera Rio } \\
\text { Miño: } 9 \\
\text { Este de la } \\
\text { frontera Rio } \\
\text { Guadiana: } 2\end{array}$ & $\left\{\begin{array}{l}\text { todo el año } \\
.\end{array}\right.$ \\
\hline \multicolumn{7}{|l|}{ Especies pelágicas } \\
\hline - Jurel & 2.250 & $\begin{array}{l}\text { C I E M } \\
\text { VIII + IX + COPACE } \\
\text { (costa continental) }\end{array}$ & arrastre & & todo el año & . \\
\hline $\begin{array}{l}\text { - Grandes migradores } \\
\text { distintos del atún: pez } \\
\text { espada, marrajo, palo- } \\
\text { meta }\end{array}$ & & $\begin{array}{l}\text { C I E M } \\
\text { VIII + IX + COPACE } \\
\text { (costa continental) }\end{array}$ & $\begin{array}{c}\text { palangre de } \\
\text { superficie }\end{array}$ & . & 20 & todo el año \\
\hline - Aṭún blanco & & $\begin{array}{l}\text { C I E M } \\
\text { VIII + IX + COPACE } \\
\text { (costa continental) }\end{array}$ & curricán & & a determinar & de $\underset{\text { julio }}{\text { mayo }}$ \\
\hline
\end{tabular}


3. Se prohibe el empleo de artes de enmallar.

4. Cada palangrero podrá largar un máximo de dos palangres por día; la longitud máxima de cada uno de estos palangres se fija en 20 millas marinas; la distancia entre anzuelos no podrá ser inferior a $2,70 \mathrm{~m}$.

5. La pesca de crustáceos no estará autorizada. Sin embargo se permitirán capturas como consecuencia de la pesca dirigida hacia la merluza y a las demás especies demersales hasta un máximo del 10 por 100 del volumen de las capturas de estas especies a bordo.

6. El número de barcos autorizados a pescar el atún blanco será aprobado antes del 1 de marzo de 1986 con arreglo al procedimiento previsto en el artículo 11 del Reglamento (CEE) número 170/83.

7. Las modalidades de aplicación de las disposiciones del presente artículo se establecerán, por analogía con las incluidas en el anexo XI, antes del 1 de enero de 1986 con arreglo al procedimiento del artículo 14 del Reglamento (CEE) número $170 / 83$.

8. Las disposiciones que tengan por objeto garantizar el respeto, por parte de los operadores, de la normativa prevista en el presente artículo, incluyendo las que contemplen la posibilidad de no autorizar el barco de que se trate a pescar durante un periodo determinado, serán aprobadas antes del 1 de enero de 1986 con arreglo al procedimiento previsto en el artículo 11 del Reglamento (CEE) número $170 / 83$.

Art. 166. El régimen definido en los artículos 156 a 164, incluidas las adaptaciones que podrán aprobarse por el Consejo en virtud del artículo 162, seguirá siendo aplicable hasta la fecha en que expire el periodo previsto en el apartado 3 del artículo 8 del Reglamento (CEE) número 170/83.

\section{Sección III.-Recursos externos}

Art. 167. 1. Desde el momento de la adhesión, la gestión de los acuerdos de pesca celebrados por el Reino de
España con terceros países se llevará a cabo por la Comunidad.

2. Los derechos y obligaciones que se deriven para el Reino de España de los acuerdos contemplados en el primer párrafo se mantendrán inalterados durante el periodo en que las disposiciones de dichos acuerdos sean mantenidas provisionalmente.

3. Tan pronto como sea posible y en todo caso antes. de la expiración de los acuerdos contemplados en el apartado 1 , el Consejo, por mayoria cualificada y a propuesta de la Comisión, tomará las decisiones apropiadas para la preservación de las actividades de pesca que de ellos se deriven, incluida la posibilidad de prorrogar determinados acuerdos por un período de un año como máximo.

Art. 168. 1. Las exoneraciones, suspensiones 0 contingentes arancelarios concedidos por el Reino de España para los productos de la pesca procedentes de las empresas conjuntas constituidas entre personas fisicas o juridicas de España y de terceros países serán eliminados de la manera siguiente durante un periodo de siete años:

\begin{tabular}{c|c|c}
\hline & $\begin{array}{c}\text { Cantidades } \\
\text { globales } \\
\text { autori- } \\
\text { ze lodo conte apertura } \\
\text { zadas con contes } \\
\text { derecho } \\
\text { nulo (t) }\end{array}$ & $\begin{array}{c}\text { Disminu- } \\
\text { cionen en } \\
\text { portaje }\end{array}$ \\
\hline del 1-3-86 al 31-12-86. & 66.300 & - \\
del 1-1-87 al 31-12-87. & 62.985 & 5,0 \\
del 1-1-88 al 31-12-88. & 56.355 & 10,5 \\
del 1-1-89 al 31-12-89. & 46.410 & 17,6 \\
del 1-1-90 al 31-12-90. & 34.808 & 24,9 \\
del 1-1-91 al 31-12-91. & 23.206 & 33,3 \\
del 1-1-92 al 31-12-92. & 11.603 & 50,0 \\
del 1-1-93 en adelante. & 0 & 100,0 \\
\hline
\end{tabular}

2. Dentro de las cantidades globales autorizadas anualmente, el reparto de los contingentes por partidas o subpartidas del arancel aduanero común se efectuará proporcionalmente según el reparto existente en 1983.

3. Los productos importados bajo este régimen no podrán considerarse en 
libre práctica en el sentido contemplado en el artículo 10 del Tratado CEE cuando se reexporten a otro Estado miembro.

4. Sólo podrán acogerse a las medidas previstas en el presente artículo los productos de las empresas conjuntas y de los barcos explotados por dichas empresas cuya lista se incluye en el anexo XII.

5. Las modalidades de aplicación del presente articulo, en particular las cantidades anuales de los contingentes por partidas o subpartidas del arancel aduanero común, asi como la lista mencionada en el ápartado 4, se establecerán con arreglo al procedimiento del artículo 33 del Reglamento (CEE) número $3796 / 81$.

\section{Sección IV.-Organización común de mercados}

Art. 169. 1. Los precios de orientación aplicables en España a las sardinas del Atläntico y a los boquerones asi como los precios de orientación aplicables en la Comunidad en su composición actual serán objeto de una aproximación con arreglo a las disposiciones de los apartados 2 y 3 , produciéndose la primera aproximación el 1 de marzo de 1986.

2. En cuanto a las sardinas del Atlántico, los precios de orientación aplicables en España por una.parte y en la Comunidad en. su composición actual por otra parte serán objeto de una aproximación, en diez etapas anuales, hacia el nivel del precio de orientación de las sardinas del Mediterráneo sobre la base de los precios de 1984, en un décimo, un noveno, un octavo, un séptimo, un sexto, un quinto, un cuarto, un tercio y en la mitad sucesivamente de la diferencia entre dichos precios de orientación aplicables antes de cada aproximación; el precio que resulte de este cálculo se modulará proporcionalmente en función de la eventual adaptación del precio de orientación para la campaña siguiente; el precio común se aplicará a partir de la fecha de la décima aproximación.

3. En cuanto a los boquerones, los precios de orientación aplicables respectivamente en España y en los demás Estados miembros serán objeto de una aproximación en cinco etapas anuales, en un quinto, un cuarto, un tercio y en la mitad sucesivamente de la diferencia entre esos precios de orientación, aplicándose dicha aproximación por mitades a cada uno de esos precios mediante aumento del precio inferior y disminución del superior; el precio que resulte de este cálculo se modulará proporcionalmente en función de la eventual adaptación del precio de orientación para la campaña siguiente; el precio común se aplicará a partir de la fecha de la quinta aproximaciọn.

Art. 170. 1. Durante el periodo de aproximación de los precios contemplados en el artículo 169, se creará un sistema de vigilancia basado en los precios de referencia aplicables:

- a las importaciones de sardinas del Atlántico en la Comunidad en su composición actual, procedentes de España,

- a las importaciones de boquerones en España, procedentes de los demás Estados miembros de la Comunidad.

2. En el momento de iniciarse cada etapa de aproximación de $\cdot$ los precios, los precios de referencia contemplados en el apartado 1 se fijarán al nivel de los precios de retirada aplicables respectivamente en España para los boquerones y en los demás Estados miembros para las sardinas del Mediterráneo.

3. En caso de perturbación del mercado a consecuencia de las importaciones contempladas en el apartado 1 , efectuadas a precios inferiores a los de referencia, se podrán tomar medidas análogas a las previstas en el artículo 21 del Reglamento (CEE) número $3.796 / 1981$; con arreglo al procedimiento del artículo 33 de dicho Reglamento. 
4. Las modalidades de aplicación del presente articulo se establecerán con arreglo al procedimiento del artículo 33 del Reglamento (CEE) número 3.796/1981.

Art. 171. 1. Desde el momento de la adhesión se implantará un régimen de indemnizaciones compensatorias para los productores de sardinas de la Comunidad en su composición actual en relación con el sistema particular de aproximación de precios aplicable a esta especie en virtud del apartado 2 del articulo 169.

2. Antes del final del periodo de aproximación de precios, el Consejo, por mayoria cualificada y a propuesta de la Comisión, decidirá si, y en su caso, en qué medida, debe prorrogarse el régimen contemplado en el presente artículo.

3. El Consejo, por mayoría cualificada y a propuesta de la Comisión, aprobará, antes del 31 de diciembre de 1985, las modalidades de aplicación del presente articulo.

Art. 172. Durante el período de aproximación de precios, los coeficientes de adaptación aplicables en 1984 a las sardinas, previstos en el apartado 1 del artículo 12 del Reglamento (CEE) número 3.796/1981, no se modificarán.

\section{Sección V.-Régimen aplicable a los intercambios}

Art. 173. 1. No obstante lo dispuesto en el artículo 31, los derechos de aduana a la importación aplicables a los productos de la pesca de las partidas y subpartidas $03.01,03.02,03.03,05.15$ A, 16.04, 16.05 y 23.01 B del arancel aduanero común, entre la Comunidad en su composición actual y España serán suprimidos progresivamente de acuerdo con el ritmo siguiente:

- el 1 de marzo de 1986 cada derecho quedará reducido al 87,5 por 100 del derecho de base;

- el 1 de enero de 1987 cada derecho quiedará reducido al 75 por 100 del derecho de base;
- el 1 de enero de 1988 cada derecho quedará reducido al 62,5 por 100 del derecho de base;

- el 1 de enero de 1989 cada derecho quedará reducido al 50 por 100 del derecho de base;

- el 1 de enero de 1990 cada derecho quedará reducido al 37,5 por 100 del derecho de base;

- el 1 de enero de 1991 cada derecho quedará reducido al 25 por 100 del derecho de base;

- el 1 de enero de 1992 cada derecho quedará reducido al 12,5 por 100 del derecho de base;

- la última reducción del 12,5 por 100 se efectuará el 1 de enero de 1993.

2. No obstante lo dispuesto en el apartado 1 , los derechos de aduana que gravan la importación de los preparados y de las conservas de sardinas de la súbpartida $16.04 \mathrm{D}$ del arancel aduanero común entre España y los demás Estados miembros de la Comunidad, se suprimirán progresivamente de acuerdo con el ritmo siguiente:

- el 1 de marzo de 1986 cada derecho quedará reducido al 90,9 por 100 del derecho de base;

- el 1 de enero de 1987 cada derecho quedará reducido al 81,8 por 100 del derecho de base;

- el 1 de enero de 1988 cada derecho quedará reducido al 72,7 por 100 del derecho de base;

- el 1 de enero de 1989 cada derecho quedará reducido al 63,6 por 100 del derecho de base;

- el 1 de enero de 1990 cada derecho quedará reducido al 54,5 por 100 del derecho de base;

- el 1 de enero de 1991 cada derecho quedará reducido al 45,4 por 100 del derecho de base;

- el 1 de enero de 1992 cada derecho quedará reducido al 36,3 por 100 del derecho de base;

- el 1 de enero de 1993 cada derecho quedará reducido al 27,2 por 100 del derecho de base; 
- el 1 de enero de 1994 cada derecho quedará reducido al 18,1 por 100 del derecho de base;

- el 1 de enero de 1995. cada derecho quedará reducido al 9 por 100 del derecho de base.

La última reducción del 9 por 100 se efectuará el 1 de enero de 1996.

3. El Reino de España eliminará desde el momento de la adhesión cualquier gravamen compensatorio sobre la importación en España de los productos contemplados en el apartado 1 procedentes de los demás Estados miembros de la Comunidad.

4. No obstante lo dispuesto en el artículo 37, el Reino de España modificará su arancel aplicable a los terceros paises, en lo referente a los productos de la pesca contemplados en el apartado 1, reduciendo la diferencia entre los derechos de base y los derechos del arancel aduanero común con arreglo a las modalidades siguientes:

- a partir del 1 de marzo de 1986 el Reino de España aplicará un derecho que reduzca en 12,5 por 100 la diferencia entre el derecho de base y el del arancel aduanero común;

- a partir del 1 de enero de 1987:

a) para las partidas arancelarias cuyos derechos de base no tengan una diferencia mayor al 15 por 100 en más o en menos respecto de los derechos del arancel aduanero común, se aplicarán estos últimos derechos;

b) en los demás casos, el Reino de España aplicará un derecho que reduzca la diferencia entre los derechos de base y los derechos del arancel aduanero común en siete movimientos iguales de 12,5 por 100 en las fechas siguientes:

- el 1 de enero de 1987;

- el 1 de enero de 1988;

- el 1 de enero de 1989;

- el 1 de enero de 1990;

- el 1 de enero de 1991;

- el 1 de enero de 1992.
El Reino de España aplicará integramente el arancel aduanero común a partir del 1 de enero de 1993.

Art. 174. 1. Hasta el 31 de diciembre de 1992, las importaciones en España de los productos que figuran en el anexo XIII, procedentes de los demás Estados miembros, estarán sometidas a un mecanismo complementario de los intercambios, definido en el presente artículo.

2. Además, hasta el 31 de diciembre de 1990, las importaciones en España de las conservas de sardina de la subpartida $16.04 \mathrm{D}$ del arancel aduanero común, procedentes de Portugal, estarán sometidas al mecanismo contemplado en el apartado 1.

3. Se establecerá un plan dé previsiones de abastecimiento de España para cada producto contemplado, antes del comienzo de cada año, sobre la base de las importaciones realizadas en el curso de los tres años anteriores. Ese plan reflejará tanto las importaciones procedentes de los demás 'Estados miembros como las procedentes de terceros países. La parte intracomunitaria en dicho plan será incrementada cada año con un factor de progresividad del 15 por 100 .

4. Más allá del umbral de la parte intracomunitaria, podrán tomarse medidas de limitación o de suspensión de las importaciones.

5. Más allá del umbral fijado para el balance global de abastecimiento, el Reino de España podrá tomar medidas cautelares inmediatamente aplicables. Dichas medidas se notificarán. sin demora a la Comisión, que podrá suspender su aplicación dentro del mes siguiente a dicha notificacion.

6. Las modalidades de aplicación se establecerán con arreglo al procedimiento previsto en el articulo 33 del Reglamento (CEE) número 3796/81.

Art. 175. 1. Las restricciones cuantitativas aplicables en la Comunidad en su composición actual a los productos procedentes de España, en las condiciones del apartado 4 del artículo 19 del Reglamento (CEE) núm. 3796/81, serán 
progresivamente suprimidas y eliminadas el 1 de enero de 1993.

2. Las modalidades de aplicación del apartado 1 se establecerán con arreglo al procedimiento del artículo $33 \mathrm{del}$ Reglamento (CEE) núm. 3796/81.

Art. 176. 1. Hasta el 31 de diciembre de 1992, para los productos que figuran en el anexo XIV, el Reino de España podrá mantener, respecto de los terceros paises, las restricciones cuantitativas aplicables en la fecha de la adhesión, dentro de los límites y con arreglo a las modalidades definidas por el Consejo por mayoria cualificada y a propuesta de la Comisión.

2. El mecanismo comunitario de los precios de referencia será aplicable respectivamente a cada producto desde el momento de la supresión de las restricciones cuantitativas correspondientes.

\section{CAPITULO V \\ RELACIONES EXTERIORES}

\section{Sección I.-Politica comercial común}

Art. 177. 1. El Reino de España mantendrá, respecto de los terceros paises, restricciones cuantitativas a la importación para los productos todavía no liberalizados réspecto de la Comunidad en su composición actual. No concederá a los terceros países ninguna otra ventaja con respecto a la Comunidad en su composición actual por lo que concierne a los contingentes fijados para dichos productos.

Dichas restricciones cuantitativas estarán vigentes por lo menos durante el tiempo en que se mantengan las restricciones cuantitativas para los mismos productos respecto de la Comunidad en su composición actual.

2. El Reino de España mantendrá respecto de los países con comercio de Estado contemplados en los Reglamentos (CEE) núm. 1765/82, núm. 1766/82 y núm. 3420/83 restricciones cuantitativas a la importación para los productos todavia no liberalizados respecto de los países a los que se aplique el Regla- mento (CEE) núm. 288/82. No concederá a los paises con comercio de Estado ninguna otra ventaja con respecto a los paises a los que se aplique el Reglamento (CEE) núm. $288 / 82$ por lo que concierne a los contingentes fijados para dichos productos.

Dichas restricciones cuantitativas estarán vigentes, por lo menos, durante el tiempo en que se mantengan las restricciones cuantitativas para los mismos productos respecto de los países contemplados en el Reglamento (CEE) núm. 288/82.

Cualquier modificación del régimen de importación en España de los productos no liberalizados por la Comunidad respecto de los países con comercio de Estado se efectuará conforme a las normas y procedimiento previstos por el Reglamento (CEE) núm. 3420/83 y sin perjuicio de lo dispuesto en el párrafo primero.

Sin embargo, el Reino de España no tendrá la obligación de reintroducir respecto a los paises de comercio de Estado, restricciones cuantitativas a la importación para los productos liberalizados respecto de dichos países y que estén aún sometidos a restricciones cuantitativas respecto de paises miembros del Acuerdo General sobre Aranceles y Comercio.

3. Hasta el 31 de diciembre de 1991, el Reino de España podrá mantener, sin perjuicio de lo dispuesto en los apartados 1 y.2, restricciones cuantitativas a la importación, en forma de contingentes, para los productos y las cantidades indicados en el-anexo XV en concepto de excepciones temporales a los regímenes comunes de liberalización de las importaciones previstos por los Reglamentos (CEE) núm. 288/82, núm. 1765/82, núm. $1766 / 82$ y núm. $3419 / 83$, modificado por el Reglamento (CEE) núm. $453 / 84$, a condición de que, en lo que respecta a los países miembros del Acuerdo General sobre Aranceles y Comercio, dichas restricciones hayan sido notificadas antes de la adhesión en el marco de dicho Acuerdo. 
$」$ Las importaciones de dichos productos quedarán íntegramente sometidas a los regímenes comunes de liberalización en vigor el 1 de enero de 1992. Los contingentes serán aumentados progresivamente hasta dicha fecha, de conformidad con el apartado 4.

4. El ritmo mínimo de aumento progresivo de los contingentes contemplados en el apartado 3 será del 17 por 100 al comienzo de cada año en lo concerniente a los contingentes expresados en ECUs y del 12 por 100 al comienzo de cada año por lo que respecta a los contingentes expresados en volumen. Este aumento se añadirá a cada contingente y el aumento siguiente se calculará partiendo de la cifra total obtenida.

Sin perjuicio de lo dispuesto en los apartados 1 y 2 , cuando las importaciones efectuadas en el transcurso de dos años consecutivos sean inferiores al 90 por 100 de los contingentes anuales abiertos de conformidad con el apartado 3, el Reino de España suprimirá las restricciones cuantitativas vigentes.

5. El Reino de España mantendrá restricciones cuantitativas a la importación, en forma de contingentes, respecto de todos los terceros países para los productos indicados en el anexo XVI, que no están liberalizados por la Comunidad respecto de los terceros países y para los que mantendrá restricciones cuantitativas a la importación respecto de la Comunidad en su composición actual, por las cantidades y al menos hasta las fechas respectivamente previstas en el mencionado anexo.

Cualquier modificación del régimen de importación en España de los productos contemplados en el párrafo primero deberá efectuarse de conformidad con las normas y procedimientos previstos por los Reglamentos (CEE) núm. 288/82 y núm. 3420/83 sin perjuicio de lo dispuesto en los apartados 1 y 2.

6. Para conformarse a las obligaciones que incumben a la Comunidad en virtud del Acuerdo General sobre Aranceles y Comercio respecto de los paises con comercio de Estado miembros del
Acuerdo, el Reino de España, en su caso y en la medida necesaria, extenderá a los referidos paises las medidas de liberalización que deberá adoptar respecto de los restantes terceros países miembros del Acuerdo, teniendo en cuenta al mismo tiempo las medidas transitorias convenidas.

Art. 178. 1. A partir del 1 de marzo de 1986, el Reino de España aplicará progresivamente el sistema de preferencias generalizadas para los productos distintos de los enumerados en el anexo II del Tratado CEE a partir de los derechos de base contemplados en el apartado 1 del artículo 30. Sin embargo en lo que respecta a los productos enumerados en el anexo XVII el Reino de España se alineará progresivamente hasta el 31 de diciembre de 1992 con los tipos del sistema de preferencias generalizadas, a partir de los derechos de base contemplados en el apartado 2 del artículo 30 . El ritmo de tales alineamientos será el mismo que el contemplado en el artículo 37 .

2. a) En relación a los productos enumerados en el anexo II del Tratado, los tipos preferenciales previstos o calculados se aplicarán progresivamente a los derechos efectivamente percibidos por el Reino de España respecto de terceros paises, con arreglo a las modalidades generales contempladas en la letra $b$ ) o a las modalidades particulares contempladas en los artículos 97 y 153.

b) El Reino de España aplicará desde el 1 de marzo de 1986 un derecho que reduzca la diferencia entre el derecho de base y el derecho preferencial según el ritmo siguiente:

- el 1 de marzo de 1986, la diferencia quedará reducida al 90,9 por 100 de la diferencia inicial;

- el 1 de enero de 1987, la diferencia quedará reducida al 81,8 por 100 de la diferencia inicial;

- el 1 de enero de 1988, la diferencia quedará reducida al 72,7 por 100 de la diferencia inicial;

- el 1 de enero de 1989, la diferencia 
quedará reducida al 63,6 por 100 de la diferencia inicial;

- el 1 de enero de 1990, la diferencia quedará reducida al 54,5 por 100 de la diferencia inicial;

- el 1 de enero de 1991, la diferencia quedará reducida al 45,4 por 100 de la diferencia inicial;

- el 1 de enero de 1992, la diferencia quedará reducida al 36,3 por 100 de la diferencia inicial;

- el 1 de enero de 1993, la diferencia quedará reducida al 27,2 por 100 de la diferencia inicial;

- el 1 de enero de 1994, la diferencia quedará reducida al 18,1 por 100 de la diferencia inicial;

- el 1 de enero de 1995, la diferencia quedará reducida al 9,0 por 100 de la diferencia inicial.

El Reino de España aplicará integramente los tipos preferenciales a partir del 1 de enero de 1996.

c) No obstante lo dispuesto en la letra b), para los productos de la pesca comprendidos en las partidas 03.01, $03.02,03.03,05.15$ A, 16.04, 16.05 y 23.01 B del arancel aduanero común, el Reino de España aplicará desde el 1 de marzo de 1986 un derecho que reduzca la diferencia entre el tipo del derecho de base y el tipo del derecho preferencial conforme al sisiema siguiente:

- el 1 de marzo de 1986, la diferencia quedará reducida al 87,5 por 100 de la diferencia inicial;

- el 1 de enero de 1987 , la diferencia quedará reducida al 75 por 100 de la. diferencia inicial;

- el 1 de enero de 1988, la diferencia quedará reducida al 62,5 por 100 de la diferencia inicial;

- el 1 de enero de 1989, la diferencia quedará reducida al 50 por 100 de la diferencia inicial;

- el 1 de enero de 1990, la diferencia quedará reducida al 37,5 por 100 de la diferencia inicial;

- el 1 de enero de 1991, la diferencia quedará reducida al 25 por 100 de la diferencia inicial;
- el 1 de enero de 1992, la diferencia quedará reducida al 12,5 por 100 de la diferencia inicial.

El Reino de España aplicará íntegramente los tipos preferenciales a partir del 1. de enero de 1993.

Sección II.-Acuerdos de las Comunidades con determinados terceros países

Art. 179. 1. El Reino de España aplicará, desde el 1 de enero de 1986, las disposiciones de los acuerdos contemplados en el artículo 181 .

Las medidas transitorias y las eventuales adaptaciones serán objeto de protocolos celebrados con los países contratantes e incorporados a dichos acuerdos.

2. Estas medidas transitorias tendrán por objeto garantizar, después de su expiración; la aplicación, por parte de la Comunidad, de un régimen común en sus relaciones con cada tercer pais cocontratante, así como la identidad de los derechos y las obligaciones de los Estados miembros.

3. Dichas medidas transitorias aplicables a los países enumerados en el artículo 181 no implicarán, en ningún sector, la concesión por el Reino de España a dichos paises de un trato más favorable que el aplicable a la Comunidad en su composición actual.

En particular, todos los productos que sean objeto de medidas transitorias en lo que respecta a las restricciones cuantitativas aplicables a la Comunidad en su composición actual estarán sujetos a tales medidas respecto de los paises enumerados en el artículo 181, durante un periodo de tiempo idéntico.

4. Dichas medidas transitorias aplicables a los paises enumerados en el artículo 181 no implicarán la aplicación por el Reino de España respecto de dichos paises de un trato menos favorable que el aplicado a los otros terceros países. En particular, no podrán preverse medidas transitorias en materia de restricciones cuantitativas respecto de los países enumerados en el artículo 181 para los productos exentos de tales res- 
tricciones a su importación en España cuando procedan de otros paises terceros.

Art. 180. 1. Si el 1 de enero de 1986 no se hubieren acordado los protocolos contemplados en el apartado 1 del artículo 179, la Comunidad adoptará las medidas necesarias para corregir, desde el momento de la adhesión, dicha situación.

El Reino de España aplicará, en cualquier caso, el trato de nación más favorecida, desde el 1 de enero de 1986, a los paises enumerados en el articulo 181.

2. Por lo que se refiere a las medidas mencionadas en el apartado 1, se aplicarán las siguientes disposiciones:

i) en caso de que los mencionados protocolos no se hayan celebrado en la fecha de la adhesión, por razones ajenas a la voluntad de la Comunidad o del Reino de España, las medidas que deberá adoptar la Comunidad preverán, en cualquier caso, la aplicación por el Reino de España, desde la fecha de la adhesión, respecto de los paises cocontratantes preferenciales o asociados a la Comunidad, del trato de nación más favorecida; asimismo, tendrán en cuenta el régimen que los terceros paises de que se trate apliquen al Reino de España en dicha fecha;

ii) en caso de que los mencionados protocolos no se hayan celebrado en la fecha de la adhesión, por motivos distintos a los citados en el inciso i), la Comunidad, para la adopción de las medidas citadas en el apartado 1 , tomará como base las medidas transitorias y las adaptaciones convenidas. en la Conferencia y, llegado el caso, tendrá en cuenta el resultado alcanzado en las negociaciones con los terceros paises afectados.

Art. 181. 1. Lós artículos 179 y 180 serán aplicables:

- a los acuerdos celebrados con Argelia, Austria, Chipre, Egipto, Finlandia, Islandia, Israel, Jordania, Líbano, Malta, Marmuecos, Noruega, Suecia, Suiza, Siria, Túnez, Turquía y Yugos- lavia, asi como a los demás acuerdos celebrados con terceros paises relativos exclusivamente a los intercambios de productos del anexo II del Tratado CEE;

- al nuevo acuerdo entre la Comunidad y los países de Africa, del Caribe y del Pacífico, firmado el 8 de diciembre de 1984.

2. Los regímenes resultantes del segundo convenio ACP-CEE y del acuerdo relativo a los productos que son de la competencia de la Comunidad Europea del Carbón y del Acero, firmados el 31 de octubre de 1979, no serán aplicables en las relaciones entre el Reino de España y los Estados de Africa, del Caribe y del Pacífico.

Art. 182. El Reino de España denunciará, con efectos a partir del 1 de enero de 1986, el acuerdo firmado el 26 de junio de 1979 con los paises de la Asociación Europea de Libre Cambio.

\section{Sección III.-Textiles}

Art. 183. 1. Desde el 1 de enero de 1986, el Reino de España aplicará el Acuerdo de 20 de diciembre de 1973 relativo al comercio internacional de los textiles, así como los acuerdos bilaterales celebrados por la Comunidad en el marco de dicho Acuerdo o con otros terceros países. Los protocolos de adaptación de esos acuerdos serán negociados por la Comunidad con los terceros países partes en los acuerdos, a fin de prever una restricción voluntaria de las exportaciones. a España respecto de aquellos productos $y$ origenes cuyas exportaciones a la Comunidad son objeto de limitaciones.

2. Si no se hubieren acordado dichos protocolos el 1 de enero de 1986 , la Comunidad adoptará las medidas destinadas a corregir dicha situación; dichas medidas se referirán a las adaptaciones transitorias necesarias para garantizar la aplicación de los acuerdos por la Comunidad. 


\section{CAPITULO VI}

\section{Disposiciones finanCIERAS}

Art. 184. 1. La Decisión de 21 de abril de 1970 relativa a la sustitución de las contribuciones financieras de los Estados miembros por recursos propios de las Comunidades, denominada en lo sucesivo "Decisión de 21 de abril de 1970 m, se aplicará con arreglo a los artículos 185 a 188.

2. Cualquier referencia a la Decisión de 21 de abril de 1970 hecha en los artículos del presente capitulo se entenderá referida a la Decisión del Consejo de 7 de mayo de 1985 , sobre el sistema de recursos propios de la Comunidad desde la entrada en vigor de esta última Decisión.

Art. 185. Los ingresos denominados "exacciones reguladoras agrícolas» contemplados en la letra a) del párrafo primero del artículo 2 de la Decisión de 21 de abril de 1970, comprenderán también los ingresos procedentes de cualquier montante liquidado sobre las importaciones en los intercambios entre España y los demás Estados miembros y entre España y los terceros países, de conformidad con los artículos 67 a 153, con el apartado 3 del artículo 50 y con el artículo 53.

Sin embargo, estos ingresos comprenderán los gravámenes compensatorios liquidados sobre las frutas y hortalizas a los que se refiere el Reglamento (CEE) número 1035/72 importadas en España, solamente a partir del 1 de enero de 1990.

Estos ingresos no comprenderán los posibles montantes percibidos sobre las importaciones en las islas Canarias y en Ceuta y Melilla.

Art. 186. Los ingresos denominados "derechos de aduana», contemplados en la letra b) del párrafo primero del artículo 2 de la Decisión de 21 de abril de 1970, comprenderán, hasta el 31 de diciembre de 1992, los derechos de aduana calculados como si el Reino de España aplicase desde el momento de la adhesión, en los intercambios con los países terceros, los tipos que resulten del arancel aduanero común y los tipos reducidos que resulten de cualquier preferencia arancelaria aplicada por la Comunidad. Para los derechos de aduana relativos a las semillas y frutos oleaginosos y sus productos derivados, a que se refiere el Reglamento número 136/66/CEE así como a las frutas y hortalizas a que se refiere el Reglamento (CEE) número $1035 / 72$, se aplicará la misma norma hasta el 31 de diciembre de 1995.

Sin embargo, estos ingresos comprenderán los derechos de aduana así calculados para las frutas y hortalizas a que se refiere el Reglamento (CEE) número 1035/72 importados en España, solamente a partir del 1 de enero de 1990.

En el caso de que se apliquen las disposiciones adoptadas por la Comisión en virtud del apartado 3 del artículo 50 de la presente Acta y no obstante lo dispuesto en el párrafo primero, los derechos de aduana corresponderán al importe calculado con arreglo al tipo de la exacción reguladora compensatoria fijado por tales disposiciones para los productos terceros que hayan intervenido en la fabricación.

Estos ingresos no comprenderán los posibles montantes percibidos sobre la importación en las islas Canarias y en Ceuta y Melilla.

El Reino de España procederá mensualmente al cálculo de dichos derechos de aduana sobre la base de las declaraciones en aduana correspondientes a un mismo mes. La puesta a disposición de la Comisión se producirá, en las condiciones definidas por el Reglamento (CEE/Euratom/CECA) número $2891 / 77$, para los derechos de aduana así calculados en función de las liquidaciones efectuadas durante el mes en cuestión.

A partir del 1 de enero de 1993, deberá aportarse integramente la totalidad de los derechos de aduana liquidados. Sin embargo, en lo que respecta a las frutas y hortalizas a que se refiere el Reglamento (CEE) número 1035/72, asi 
como para las semillas oleaginosas y sus productos derivados regulados por el Reglamento número 136/66/CEE, deberá aportarse íntegramente la totalidad de los derechos a partir del 1 de enero de 1996.

Art. 187. Desde el 1 de enero de 1986 deberá aportarse íntegramente el importe de los derechos liquidados en concepto de recursos propios procedentes del impuesto sobre el valor añadido.

Este importe se calculará y controlará como si las islas Canarias y Ceuta y Melilla estuvieran incluidas en el ámbito territorial de aplicación de la Sexta Directiva número 77/388/CEE del Consejo, de 17 de mayo de 1977 , en materia de armonización de las legislaciones de los Estados miembros relativas a los impuestos sobre el volumen de negocios -sistema común del impuesto sobre el valor añadido: base imponible uniforme.

La Comunidad restituirá al Reino de España en concepto de gastos del presupuesto general de las Comunidades Europeas, durante el mes siguiente a la puesta a disposición de la Comisión, un porcentaje del importe de los desembolsos en concepto de los recursos propios procedentes del impuesto sobre el valor añadido según las modalidades siguientes:

87 por 100 en 1986

70 por 100 en 1987

55 por 100 en 1988

40 por 100 en 1989

25 por 100 en 1990

5 por 100 en 1991 .

El porcentaje de esta restitución decreciente no se aplicará al importe correspondiente a la parte que incumba a España en la financiación de la deducción prevista en las letras b) y c) del apartado 3 del artículo 3 de la Decisión del Consejo de 7 de mayo de 1985 sobre los recursos propios de las Comunidades, a favor del Reino Unido.

Art. 188. Con objeto de evitar que el Reino de España deba soportar el reembolso de los anticipos concedidos a la
Comunidad por sus Estados miembros antes del 1 de enero de 1986 , el Reino de España se beneficiará de una compensación financiera por el concepto de dicho reembolso.

\section{QUINTA PARTE}

\section{Disposiciones relativas a la aplica- ción de la presente Acta}

\section{TITULO PRIMERO}

\section{Constitucion de las instituciones}

Art. 381. La Asamblea se reunirá, a más tardar, un mes después de la adhesión. Efectuará en su reglamento interno las adaptaciones que resulten necesarias a consecuencia de esta adhesión.

Art. 382. El Consejo efectuará en su reglamento interno las adaptaciones que resulten necesarias a consecuencia de la adhesión.

Art. 383. 1. Desde el momento de la adhesión, la Comisión quedará completada con el nombramiento de tres miembros suplementarios y la designación de un sexto vicepresidente entre los miembros de la Comisión ampliada. El mandato de los miembros asi nombrados concluirá al mismo tiempo que el de los miembros que sigan desempeñando sus funciones en el momento de la adhesión.

El mandato del sexto vicepresidente designado concluirá en la misma fecha que el de los otros cinco vicepresidentes.

2. Antes del 31 de diciembre de 1986, el Consejo examinará por vez primera si procede aplicar el párrafo cuarto del artículo 14 del Tratado por el que se constituye un Consejo único y una Comisión única de las Comunidades Europeas.

3. La Comisión efectuará en su reglamento interno las adaptaciones que resulten necesarias a consecuencia de la adhesión. 
Art. 384. 1. Desde el momento de la adhesión, el Tribunal de Justicia quedará completado con el nombramiento de dos jueces.

2. El mandato de uno de los jueces nombrados de conformidad con el apartado 1 expirará el 6 de octubre de 1988. Dicho juez será designado por sorteo. El mandato del otro juez expirará el 6 de octubre de 1991.

3. Desde el momento de la adhesión, se nombrará un sexto abogado general. Su mandato expirará el 6 de octubre de 1988.

4. El Tribunal efectuará en su regla. mento de procedimiento las adaptaciones que resulten necesarias a consecuencia de la adhesión. El reglamento de procedimiento asi adaptado será sometido a la aprobación unánime del Consejo.

5. Para fallar en los asuntos pendientes ante el Tribunal el 1 de enero de 1986, respecto de los que se hubiese iniciado ya antes de esta fecha el procedimiento oral, el Tribunal en sesión plenaria o las Salas se reunirán tal como estaban compuestos antes de la adhesión y aplicarán el reglamento de procedimiento vigente el 31 de diciembre de 1985.

Art. 385. Desde el momento de la adhesión, el Tribunal de Cuentas quedará completado con el nombramiento de dos miembros suplementarios. El mandato de los miembros asi nombrados concluirá el 17 de octubre de 1987.

Art. 386. Desde el momento de la adhesión, el Comité Económico y Social quedará completado con el nombramiento de treinta y tres miembros que representen a los diferentes sectores de la vida económica y social de los nuevos Estados miembros. El mandato de los 'miembros así nombrados concluirá al mismo tiempo que el de los miembros que sigan desempeñando sus funciones en el momento de la adhesión.

Art. 387. Desde el momento de la adhesión, el Comité Consultivo de la Comunidad Europea del Carbón y del
Acero quedará completado con el nombramiento de miembros suplementarios. El mandato de los miembros asi nombrados concluirá al mismo tiempo que el de los miembros que sigan desempeñando sus funciones en el momento de la adhesión.

Art. 388. Desde el momento de la adhesión, el Comité Científico y Técnico quedará completado con el nombramiento de cinco miembros suplementarios. El mandato de los miembros asi nombrados concluirá al mismo tiempo que el de los miembros que sigan desempeñando sus funciones en el momento de la adhesión.

Art. 389. Desde el momento de la adhesión, el Comité Monetario quedará completado con el nombramiento de miembros que representen a los nuevos Estados miembros. Su mandato concluirá al mismo tiempo que el de los miembros que sigan desempeñando sus funciones en el momento de la adhesión.

Art. 390. Las adaptaciones de los estatutos y de los reglamentos internos de los comités creados por los Tratados originarios, que resulten necesarias a consecuencia de la adhesión; se efectuarán tan pronto como sea posible después de la adhesión.

Art. 391. 1. El mandato de los nuevos miembros de los comités enumerados en el anexo XXXIII, concluirá al mismo tiempo que el de los miembros que sigan desempeñando sus funciones en el momento de la adhesión.

2. Los comités enumerados en el anexo XXXIV. serán enteramente renovados en el momento de la adhesión.

\section{TITULO II}

\section{Aplicabilidad de los actos de las institu- ciones}

Art. 392. Desde el momento de la adhesión, los nuevos Estados miembros serán considerados como destinatarios y que han recibido notificación de las 
directivas y decisiones, tal como se definen en el artículo 189 del Tratado CEE y en el artículo 161 del Tratado CEEA, asi como las de las recomendaciones y decisiones defínidas en el artículo $14 \mathrm{del}$ Tratado CECA, siempre que tales directivas, recomendaciones $y$ decisiones hayan sido notificadas a todos los Estados miembros actuales.

Art. 393. La aplicación en cada uno de los nuevos Estados miembros de los actos que figuran en la lista del anexo XXXV de la presente Acta será aplazada hasta las fechas previstas en dicha lista.

Art. 394. 1. Se aplazarán hasta el 1 de marzo de 1986:

a) la aplicación a los nuevos Estados miembros de la normativa comunitaria establecida para la producción y el comercio de los productos agrícolas y para los intercambios de determinadas mercancias procedentes de la transformación de productos agricolas sometidos a un régimen especial;

b) la aplicación a la Comunidad en su composición actual de las modificaciones efectuadas en esa normativa por la presente Acta, incluidas las que resulten del artículo 396.

2. El apartado 1 no se aplicará a las adaptaciones de los actos de las Instituciones de la Comunidad que se refieren a la política agricola común que se efectuarán conforme al artículo 396 , con objeto de determinar el número de votos que representará, desde el momento de la adhesión, la mayoría cualificada en el marco del procedimiento de los Comités de gestión y otros comités similares creados en el sector de la agricultura.

3. Hasta el 28 de febrero de 1986, el régimen aplicable a los intercambios entre un nuevo Estado miembro, por una parte, y la Comunidad en su composición actual, el otro nuevo Estado miembro o los terceros países, por otra, será el que se aplicaba antes de la adhesión.
Art. 395. Los nuevos Estados miembros pondrän en vigor las medidas que les sean necesarias para cumplir, desde el momento de la adhesión, las disposiciones de las directivas y decisiones definidas en el artículo 189 del Tratado CEE y en el artículo 161 del Tratado CEEA, asi como la de las recomendaciones y decisiones definidas en el artículo 14 del Tratado CECA, a menos que se prevea un plazo en la lista que figura en el anexo XXXVI o en otras disposiciones de la presenta Acta.

Art. 396. 1. Las adaptaciones de los actos de. las instituciones de las Comunidades no contenidas en la presente Acta o en sus anexos y efectuadas por las instituciones, antes de la adhesión, según el procedimiento previsto en el apartado 2, para poner estos actos en consonancia con las disposiciones de la presente Acta, en especial con las que figuran en su cuarta parte, entrarán en vigor desde el momento de la adhesión.

2. El Consejo, por mayoría cualificada y a propuesta de la Comisión, o la Comisión, según que los actos iniciales hayan sido adoptados por una u otra de estas dos instituciones, establecerá a tal fin los textos necesarios.

Art. 397. Los textos de los actos de las instituciones de las Comunidades adoptados antes de la adhesión y establecidos por el Consejo o la Comisión en lengua española y lengua portuguesa serán auténticos, desde el momento de la adhesión, en las mismas condiciones que los textos redactados en las siete lenguas actuales. Se publicarán en el Diario Oficial de las Comunidades Europeas en los casos en que los textos en las lenguas actuales hubieren sido así publicados.

Art. 398. Los acuerdos, decisiones y prácticas concertadas existentes en el momento de la adhesión y que entren en el ámbito de aplicación del artículo 65 del Tratado CECA a consecuencia de la adhesión deberán ser notificados a la Comisión dentro de un plazo que no podrá exceder de tres meses después de 
la adhesión. Sólo los acuerdos y decisiones que hubieren sido notificados seguirán provisionalmente en vigor hasta la decisión de la Comisión.

Art. 399. Las disposiciones legales, reglamentarias y administrativas destinadas a garantizar, en el territorio de los nuevos Estados miembros, la protección sanitaria de las poblaciones y de los trabajadores contra los peligros que resulten de las radiaciones ionizantes serán comunicadas, de conformidad con el artículo 33 del Tratado CEEA, por dichos Estados a la Comisión, dentro de un plazo de tres meses a partir de la adhesion.

\section{TITULO III}

\section{Disposiciones finales}

Art. 400. Los anexos I a XXXVI y los Protocolos números 1 a 25 anejos a la presente Acta serán parte integrante de ésta.

Art. 401. El Gobierno de la República Francesa remitirá a los Gobiernos del Reino de España y de la República Portuguesa una copia certificada conforme del Tratado constitutivo de la Comunidad Europea del Carbón y del Acero y de los Tratados que lo han modificado.
Art. 402. El Gobierno de la República Italiâna remitirá a los Gobiernos del Reino de España y de la República Portuguesa una copia certificada conforme del Tratado constitutivo de la Comunidad Económica Europea, del Tratado constitutivo de la Comunidad Europea de la Energía Atómica y de los Tratados que los han modificado o completado, incluidos los Tratados relativos a la adhesión a la Comunidad Económica Europea y a la Comunidad Europea de la Energía Atómica del Reino de Dinamarca, de Irlanda y del Reino Unido de Gran Bretaña e Irlanda del Norte y de la República Helénica, respectivamente; en lengua alemana, lengua danesa, lengua francesa, lengua griega, lengua inglesa, lengua irlandesa, lengua italiana y lengua neerlandesa.

Los textos de dichos Tratados, redactados en lengua española y lengua portuguesa, se adjuntarán a la presente Acta. Tales textos serán auténticos en las mismas condiciones que los textos de los Tratados mencionados en el párrafo primero, redactados en las lenguas actuales.

Art. 403. El Secretario general remitirá a los Gobiernos de los nuevos Estados miembros una copia certificada conforme de los acuerdos internacionales depositados en los archivos de la Secretaría General del Consejo de las Comunidades Europeas. 